Portland State University

PDXScholar

5-13-1996

\title{
Japanese Students' Perception of Their Language Learning Strategies
}

Michiyo Ozawa

Portland State University

Follow this and additional works at: https://pdxscholar.library.pdx.edu/open_access_etds

Part of the Bilingual, Multilingual, and Multicultural Education Commons Let us know how access to this document benefits you.

\section{Recommended Citation}

Ozawa, Michiyo, "Japanese Students' Perception of Their Language Learning Strategies" (1996). Dissertations and Theses. Paper 5160.

https://doi.org/10.15760/etd.7036

This Thesis is brought to you for free and open access. It has been accepted for inclusion in Dissertations and Theses by an authorized administrator of PDXScholar. Please contact us if we can make this document more accessible: pdxscholar@pdx.edu. 


\section{THESIS APPROVAL}

The abstract and thesis of Michiyo Ozawa for the Master of Arts in TESOL were presented on May 13, 1996, and accepted by the thesis committee and the department.

COMMITTEE APPROVALS:

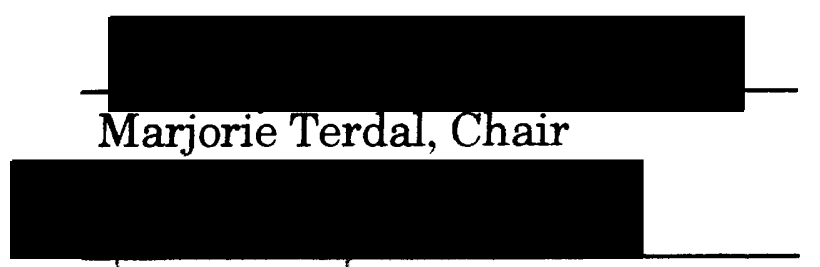

Kimberley Brown

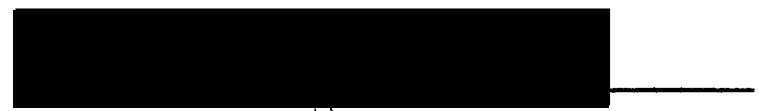

Patricia Wetzel n

DEPARTMENT APPROVAL:

Beatrice Oshika, Chair

Department of

Applied Linguistics

$* * * * * * * * * * * * * * * * * * * * * * * * * * * * * * * * * * * * * * * * * * * * * * * * * * * * * * * * * *$

ACCEPTED FOR PORTLAND STATE UNIVERSITY BY THE LIBRARY

by

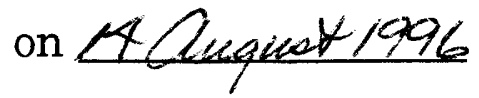


An abstract of the thesis of Michiyo Ozawa for the Master of Arts in TESOL presented May 13, 1996.

Title: Japanese Students' Perception of Their Language Learning Strategies.

Students' use of language learning strategies (LLSs) is affected by their educational backgrounds and academic requirements, and so are their attitudes toward language learning. This study investigates Japanese students' perception of their English LLSs in different language environments: Japan and the United States.

A group of 43 Japanese students from Otemae College participated in a cultural study program at Portland State University. The group consisted of 28 students who studied for two terms (ST Group) and 15 students who studied for three terms (LT Group).

In this study, a combination of a self-assessment questionnaire, dialogue journals, and a card-ranking activity was employed. The self-assessment questionnaire, SILL (Rebecca Oxford's Strategy Inventory for Language Learning), was administered at different times during the learning period for identification of students' English LLSs in Japan (L1) and in the United States (L2).

The SILL provided this study with quantitative data; 
whereas, dialogue journals and the card ranking activity supplied qualitative data that more insightfully indicated students' perception of language learning, learning experiences, and insight into the students themselves. Dialogue journals allowed students to record their positive and negative experiences in the L2 related to language learning, emotions, concerns, problems, and questions.

The students' LLSs increased in frequency and variety of use when the language environment changed from the $\mathrm{L} 1$ to the L2. The LLSs of the LT Group continued to improve during an additional term in the L2. Conversely, the LLS use by the ST Group regressed after only four months back in the L1 (except Affective and Social Strategies). The results of the SILL indicated direct strategies were adjusted according to English learning experience in a different learning environment.

Three administrations of the SILL, dialogue journals, and the card ranking activity gave students opportunities to review the process of their English learning. This process functioned in raising students' awareness of language learning from cognitive, psychological, social, and cultural perspectives. Such conceptual development of metalinguistic awareness of the language and culture helped the students recognize their language learning experiences in the L2 as the process of human development. 


\section{JAPANESE STUDENTS' PERCEPTION OF}

THEIR LANGUAGE LEARNING STRATEGIES

by

MICHIYO OZAWA

A thesis submitted in partial fulfillment of the requirements for the degree of

MASTER OF ARTS

in

TESOL

Portland State University

1996 


\section{DEDICATION}

I would like to dedicate this thesis to my parents who have always encouraged and supported me throughout my life. I greatly appreciate them for who I am today. They provided me with a loving and healthy environment in which I was able to grow not only physically, but also psychologically. 


\section{ACKNOWLEDGMENTS}

I would like to make acknowledgment to my thesis advisor, Dr. Marjorie Terdal, for her encouragement and support. Whenever I visited her, I left her office with more confidence in what I was doing for my thesis. Without her reinforcement, patience, and editing, I could not have completed my thesis.

I thank Judy Van Dyck for making the process of my thesis easier. She discussed the Otemae program with me and helped me organize and arrange Otemae students' schedule. That was a tremendous help.

I would like to express appreciation to my friends who listened to me, soothed me, inspired me, and made me laugh. Sandra Dennis and Stefán Haynes helped me go through the process especially by proofreading my thesis over and over again without any complaint. Gloria Law and Satsuki Hamasaki always believed in me and encouraged me. Peter Lewis, who kindly listened to my concerns, gave me a practical advice to finish my thesis by saying, "Get it done!"

I thank all my PSU friends for sharing their thoughts and ideas. Jay Peterson, in particular, educated me in Statistics and worked with me on the statistical analysis for my thesis.

Finally, I cannot forget to thank all of the Otemae students in the 1995 program who participated in this study for my thesis. Without them, my thesis would not have existed. I thank them for their friendship and for sharing themselves with me. 


\section{TABLE OF CONTENTS}

ACKNOWLEDGMENTS

i

LIST OF TABLES .................................................................... v

LIST OF FIGURES ............................................................... vii

CHAPTER PAGE

I INTRODUCTION .............................................................. 1

Hypotheses ...................................................................... 4

Methods......................................................................... 5

Potential Benefits of the Study ............................ 8

Glossary of Acronyms .............................................. 10

II REVIEW OF THE LITERATURE .................................. 11

Variables in Second Language Acquisition ....... 12

Intermediate Variables in the Language

Planning Process ..................................................... 13

Learner Variables ................................................... 15

Language Learning Strategies ........................... 16

Oxford's Language Learning

Strategy System ......................................................... 21

Japanese Learners' Characteristics ................. 24

English Education in Japan ................................ 28

III METHODS......................................................................... 33

Description of Subjects ......................................... 33

Design of the Survey Instruments _................ 34

Collection of Data ................................................. 38 
IV THE SURVEY INVENTORY OF LANGUAGE LEARNING: RESULTS AND DISCUSSION ............... 45

Three Administrations of the SILL .................... 45

Hypothesis \# 1 ........................................................ 47

Hypothesis \#2 ..................................................... 65

Hypothesis \# 3 ........................................................... 67

V DIALOGUE JOURNALS AND CARD RANKING ACTIVITY: RESULTS AND DISCUSSION ................ 70

Dialogue Journals:

Spring and Summer Terms _.............................. 71

Dialogue Journals of Seven Students:

Spring through Fall Terms .............................. 82

Card Ranking Activity ........................................ 87

Positive Emotions and Experiences .................... 88

Negative Emotions and Experiences .................. 90

Ranking of Subcategories of

"English Learning" ............................................... 93

VI CONCLUSION ................................................................. 96

Limitations of the Study .................................. 99

Recommendations for

Future Otemae Programs at PSU ................ 100

Suggestions for Further Research ................. 102

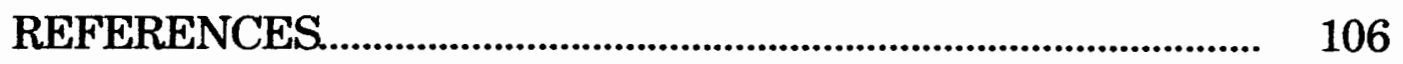


APPENDICES

A. OXFORD'S STRATEGY SYSTEM AND DEFINITIONS OF LEARNING STRATEGIES USED IN THE SILL

B. SHL SURVEY …................................................. 130

C. SILL SURVEY (JAPANESE VERSION) ........ 139

D. CARD RANKING ACTIVITY (JAPANESE VERSION)

E. SUBCATEGORY LIST:

DIALOGUE JOURNALS

F. SILL RESULTS: COMPARISON OF ALL MEDIAN SCORES BETWEEN SILLS \# 1 AND \# 2 151

G. DIALOGUE JOURNAL DATA: SPRING AND SUMMER TERMS 153

H. CARD RANKING ACTIVITY RESULTS 156 


\section{LIST OF TABLES}

TABLE

PAGE

I Three Administrations of the SILL and Two

Groups of Subjects

II Numbers of Tutoring Sessions and

Participants Per Session ........................................ 40

III Number of Dialogue Journals and Comments ... 43

IV Wilcoxon Matched-Pairs Signed-Ranks Test:

Comparisons of All Median Scores

between SILLs \#1 and \#2

V Wilcoxon Matched-Pairs Signed-Ranks Test:

Median Score Comparisons of Memory

Strategies between SILLs \#1 and \#2

VI Wilcoxon Matched-Pairs Signed-Ranks Test:

Median Score Comparisons of Cognitive

Strategies between SILLs \#1 and \#2

VII Wilcoxon Matched-Pairs Signed-Ranks Test:

Median Score Comparisons of Compensation

Strategies between SILLs \#1 and \#2 .................. 56

VIII Wilcoxon Matched-Pairs Signed-Ranks Test:

Median Score Comparisons of Metacognitive

Strategies between SILLs \#1 and \#2 .................. 58

IX Wilcoxon Matched-Pairs Signed-Ranks Test:

Median Score Comparisons of Affective

Strategies between SILLs \#1 and \#2 ................... 60

X Wilcoxon Matched-Pairs Signed-Ranks Test:

Median Score Comparisons of Social

Strategies between SILLs \#1 and \#2 
XI Wilcoxon Matched-Pairs Signed-Ranks Test:

Comparisons of All Median Scores between

SILLs \#2 and \#3 (LT Group)

XII Wilcoxon Matched-Pairs Signed-Ranks Test:

Comparisons of All Median Scores between

SILLs \#2 and \#3 (ST Group)

XIII Dialogue Journals Comments in Six Categories

(Sspring Summer)

XIV Four Leading Subcategories

in "English Learning"

XV Dialogue Journals: Six Categories of

Seven Students' Comments

(Spring through Fall)

XVI Wilcoxon Matched-Pairs Signed-Ranks Test:

Median Score Comparisons of Affective and

Social Strategies: SILLs \#1, \#2, and \#3

86

XVII Positive and Negative Emotionss and

Experiences: LT Group students.

XVIII Positive and Negative Emotions and

Experiences: ST Group students

XIX Subcategory Ranking of

"English Learning" 


\section{LIST OF FIGURES}

FIGURE

PAGE

1. Representation of the role of language planning in SLA.............................................................. 13

2. Diagram of the strategy system: Overview .......... 22

3. Interrelationships between direct and indirect strategies and among the six strategy groups

4. Relationships between the SILLs and the hypotheses.

5. Diagram of hypotheses and three administrations of the SILLs (LT Group) 66

6. Diagram of hypotheses and three administrations of the SILLs (ST Group) 68

7. Diagram of the SILLs, dialogue journals and the card-ranking activity. 


\section{CHAPTER I}

\section{INTRODUCTION}

The purpose of this study was to investigate Japanese college students' perceptions of English language learning by comparing their language learning strategies in their native language environment, Japan, and in their target language environment, the United States. In addition, students' positive and negative attitudes toward their learning experiences in the target language environment were studied by looking at their comments in dialogue journals and the results of a card ranking activity. These allowed the researcher to obtain and understand more insights into the students' perceptions.

The Otemae program at Portland State University (PSU) started in 1992. Otemae College in Japan has sent 15 to 45 students every year since then. In the year of this study (1995), 43 students from Otemae College participated in a cultural study program at PSU. This is the first study that has investigated Otemae students' language learning strategies in connection with their attitudes.

Language learning strategies in second language acquisition have been investigated for more than two decades. In the early 1970 's, concerns of researchers shifted from language teaching methods to individual variation in the language learning process 
(Brown, 1987; Wenden, 1987). Language learning strategies have been defined by many researchers. Most recently, Oxford (1990a) defines language learning strategies as "specific actions taken by the learner to make learning easier, faster, more enjoyable, more selfdirected, more effective, and more transferable to new situations" (p. 8). Language learning strategies can be changed, modified, and learned unlike learning styles and personality which are relatively stable (see Pressley \& Levin, 1983; Wenden, 1987).

Learning strategies of "good language learners" or "successful learners" have been studied in order to assist unsuccessful learners (see Rubin, 1975; Reiss, 1981; Oxford \& Crookall, 1989). Learning strategies of unsuccessful learners have also been studied for the same purpose (Chamot, O'Malley, Küpper, \& Impink-Hernandez, 1987; Vann \& Abraham 1990). Researchers have found that both successful and unsuccessful language learners employ a variety of learning strategies, but successful learners apply learning strategies more appropriately to the situation with better orchestration of strategy than do unsuccessful learners.

Regardless of successful or unsuccessful results, the language learning processes can be different according to the learning environment. The English learning processes of Japanese learners in their native language environment may not be the same as those in their target language environment due to the different learning situations.

Tollefson (1981) explains the learning situation as 
hierarchically affected by macro-policy goals, macro-implementation decisions, micro-policy goals, and micro-implementation decisions. English language functions multi-purposely in different situations in different countries. It serves as more than a means for communication, and is powerfully involved in social, economic, ideological, and political issues. Tollefson's point is how strongly "outside of classroom" variables often take precedence over "inside of classroom" variables.

Tollefson's claim is represented in the English educational system in Japan, where macro-policy goals along with micro-policy goals control micro-implementation decisions. The purpose of English teaching in Japan is grammar- and translation-oriented to help students pass examinations for higher education rather than communicative-oriented to help learners achieve "functional" needs and interests. This traditional Japanese educational system limits teachers' capacity to teach, and the limits of a teacher's capacity to teach limits a learner's ability to learn (Kramsch, 1988). This restriction could cause problems when Japanese learners attempt to use English as a tool of communication. In addition, Japanese group consciousness and gaps between outward expression and inner feelings may confuse people from other cultures unless they are aware of the Japanese social character. Such confusion also affects communicative competence negatively.

Under that system of English education in Japan, how do Japanese learners learn English? Which language learning 
strategies do they employ so as to succeed in learning English? In order to find answers for these questions, Oxford's strategy system can be used. Oxford (1990a) developed a strategy system by identifying 62 strategies and classifying them into six groups: memory, cognitive, compensation, metacognitive, affective, and social strategies. These six are further classified into two groups: direct (memory, cognitive, and compensation) and indirect (metacognitive, affective, and social) strategies.

Based on these classifications, the Strategy Inventory for Language Learning (SILL) was created by Oxford (1990a) in order to help learners understand their language learning strategies. One of the two versions of the SILL is for speakers of other languages learning English (Version 7.0). The SILL has been administered in many countries and even translated into different languages. By using the SILL, it is possible to investigate changes in learners' learning strategies, in particular, strategy changes in different language environments: English learning in the learners' native language (non English) environment and in the English environment.

\section{Hypotheses}

Would changing the English learning environment from Japan, the native language environment (L1), to the United States, the target language environment (L2), influence Japanese students' perceptions of their English learning strategies? Would their 
learning strategies be more affected when the students stay longer in the L2? Would their learning strategies change when they return to the L1? These questions were the beginning of this study. In order to discover answers for the questions, the following three hypotheses were investigated:

Hypothesis one.

SILL \#2 (English learning strategies in the L2, short- and longterm groups) would show an increase in median scores from SILL \#1 (English learning strategies in the L1).

\section{Hypothesis two.}

SILL \#3 (English learning strategies in the L2, long-term group) would continue to show an increase in median scores from SILL \#2 (strategies in the L2).

Hypothesis three.

SILL \#3 (English learning strategies in the L1, short-term group) would show a decrease in median scores from SILL \#2 (strategies in the L2).

\section{Methods}

Forty-three students were divided into two groups according to lengths of time spent in the L2: 28 students in a six-month shortterm group and 15 in a nine-month long-term group. Both groups of students studied together during the spring and the summer terms, and only the long-term group continued in the fall term. 


\section{Measurement instruments.}

As quantitative data, Otemae students' perceptions of the English learning strategies were examined by three administrations of the SILL: \#1, \#2, and \#3. Each SILL provided different aspects of the learning strategies of English: SILL \#1: learning strategies in the L1 (both long- and short-term groups); SILL \#2: learning strategies in the L2 (both long- and short-term groups); and SILL \#3: learning strategies in the L2 (long-term group) and learning strategies in the L1 (short-term group).

To serve as qualitative data, comments that Otemae students wrote in dialogue journals were closely studied. Based on the comments, a card ranking activity was designed. The results of this activity provided both quantitative and qualitative data for the study. Measurement instruments used in the study were all translated into the Japanese language due to the students' limited English proficiency.

\section{Data collection and analysis: SILL.}

SILL \#1 was given to both short- and long-term groups of students in the spring term; they thought about learning strategies of English that they used in the L1. SILL \#2 was given also to both groups of students at the end of the summer term, four months after SILL \#1; they reported their learning strategies that they employed in the L2. SILL \#3 was administered to 14 out of 15 longterm group students in the L2 in the fall term, four months after 
SILL \#2. At the same time, SILL \#3 was also mailed to 27 shortterm group students in Japan who had been in the L1 for four months after leaving the L2. Seventeen of the 27 students responded to SILL \#3 completed in the L1, but two of the 17 were excluded due to no response to one or both of the previous SILLs.

Median scores between SILLs \#1 and \#2, and SILLs \#2 and \#3 were statistically compared to determine the students' frequency of strategy use. Because of the ordinal nature of the data, median scores were employed instead of mean scores.

Data collection and analysis: Comments in dialogue journals.

The Otemae program offered the students weekly tutoring sessions on a voluntary basis. Students who attended the sessions kept dialogue journals, by writing their thoughts, feelings, concerns, problems, and experiences in the L2. Their comments from the dialogue journals were classified into six categories and then into forty subcategories. The number of comments were taken to illustrate the students' attention; a greater number of comments indicated greater attention of students.

\section{Data collection and analysis: A card ranking activity.}

The 40 subcategories of the comments in dialogue journals were used in a card ranking activity which illustrated the students' positive and negative attitudes and feelings toward their experiences in the L2. When SILL \#3 was given, 14 long-term group students participated in the card ranking activity in the $\mathrm{L} 2$, and 17 short-term 
group completed the activity in the $L 1$. When given a set of 40 cards (subcategories), each student chose 10 cards which represented her negative experiences in the L2 and ranked them from the most negative, 1 , to the least, 10 . Again each student chose 10 out of the 40 cards but this time those cards which exhibited her positive experiences in the $\mathrm{L} 2$, and ranked them from the most positive, 1 , to the least, 10.

Subcategories were ranked in two steps: first, by the number of students, and then, by median scores. A subcategory with a greater number of students and a smaller median score was placed higher in the overall ranking system.

\section{Potential Benefits of the Study}

This study will help the Otemae program in many ways. First of all, in a practical way, the program coordinators of both Otemae College and PSU with American Heritage Association should have a better understanding of the particular needs and perspectives of Otemae students.

Second, the students' level of awareness of language learning strategies should be raised. The students will be able to employ more variety of learning strategies consciously. Strategies that are likely to be used more in the L2 can be introduced before the students leave the L1. This could lead to greater success in their English learning as well.

Third, similar to the second issue, students' concept of English 
language learning should be deepened and broadened not only in a linguistic grammatical way, but also in communicative, social, and cultural ways. The students in the 1995 program realized the complexity of language learning that involves different layers of understanding between their native language and culture and their target language and culture, and between themselves in the L1 and themselves in the L2.

This psychological involvement is nearly impossible for the students to experience within the L1, and their experiences facilitate the process of their language learning and self-improvement. The students in the 1995 program eventually paid more attention to their learning experiences in the L2 (i.e. indirect strategies) rather than only linguistic grammatical improvement (i.e. direct strategies), which they were concerned with initially. Those who perceived their learning process in a productive way interpreted their experiences in the L2 as the most beneficial learning process in the United States, which then increased the students' interest and motivation to learn. This helped the students become more autonomous and responsible for their own language learning, which led them to succeed in language learning.

All of these advantages will help the Otemae program in the future; Otemae students who will participate in the program can prepare themselves better and reduce unnecessary stress, by raising their consciousness of language learning and learning strategies, and by receiving information about what experiences Otemae students 
went through in the program previously.

\section{Glossary of Acronyms}

The following acronyms are used in this paper:

EFL: $\quad$ English as a Foreign Language

ESL: $\quad$ English as a Second Language

L1: Native Language Environment (Japan)

L2: Target Language Environment (the United States.)

LLSs: Language Learning Strategies for English

LT Group: Long-Term Group

SILL: The Strategy Inventory for Language Learning

SLA: Second Language Acquisition

ST Group: Short-Term Group 


\section{CHAPTER II}

\section{REVIEW OF THE LITERATURE}

This study is about Japanese university students' perception of their language learning strategies (LLSs), so this literature review will focus on learner variables, LLSs, traits of Japanese learners, and Japanese English education policy and system. They are the primary factors in the English learning process in Japan. The selfreport questionnaire of LLSs designed by Oxford (1990a) is used as an instrument in this study, so her view of LLSs will be discussed extensively.

"So many men, so many minds." This saying relates to "so many learners, so many variables." Researchers have investigated "many variables" that affect second language acquisition (SLA) in order to understand the process of SLA and make the learning process successful. The learning processes of English as a Second Language (ESL) may not be the same as those of English as a Foreign Language (EFL). Learners in the United States, an ESL situation for example, experience different learning processes from those who learn English in Japan, an EFL situation. Tollefson (1981) explains the learning situation, outside the United States, where language learning functions in countries' modernization and development plans and in ethnic, religious, economic, and political 
struggles. Language is considered "a symbol and a means to achieve mobility, social and economic advancement, and political power" (p. 347). This is the tradition of the English learning situation in Japan.

Tollefson (1981) discusses language situation variables in SLA from the view of language planning. Language situation variables in the planning process contain "macro-policy goals," "macroimplementation decisions," "micro-policy goals," and "microimplementation decisions." These factors as "intermediate variables" play a decisive role in the following variables: input variables, learner variables, learning variables, and learned variables (Tollefson, 1981). Variables and factors in different levels closely influence SLA both positively and negatively. The variables listed above will be defined later.

\section{Variables in Second Language Acquisition}

SLA research often involves the "unplanned variables" (Tollefson, 1981) of input, learner, learning, and learned (Swain, 1979). In addition to these, Tollefson (1981) claims there are "planned variables" which impact SLA process and proposes his own set of intermediate planned variables that contain a complicated series of policy levels which influence SLA ultimately. Figure 1 explains how planned and unplanned variables are related in the language planning in SLA. 
Language Situation Variables

* Macro-Policy Goals

$\downarrow$

*Macro-Implementation Decisions

* Micro-Policy Goals

$\downarrow$

*Micro-Implementation Decisions

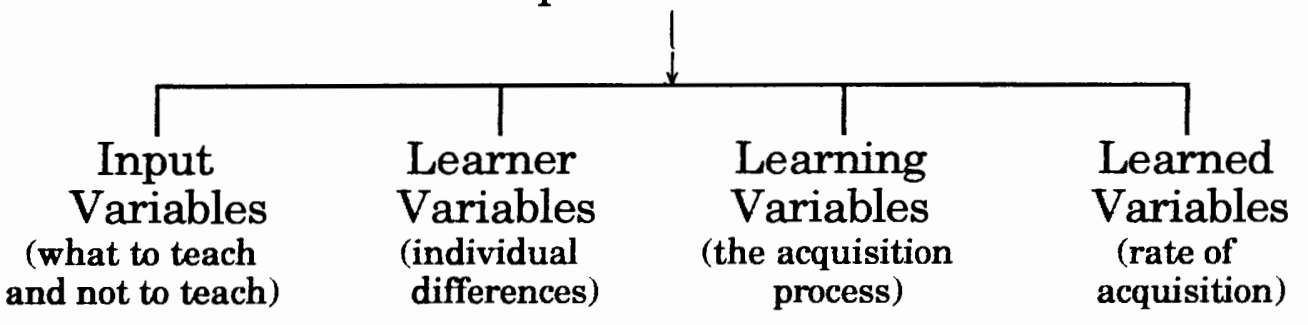

Figure 1. Representation of the role of language planning in SLA (Tollefson, 1981, p. 340) *Intermediate planned variables (Asterisks and explanation in parentheses added by the researcher)

\section{Intermediate Variables in the Language Planning Process}

Macro-policy goals and Macro-implementation decisions.

Macro-policy goals, "the aims of plans formulated by authorities with responsibility for the national community" (Tollefson, 1981,

p. 343), include three types: "(1) language maintenance or shift, (2) structural changes in a variety, and (3) changes in the functional distribution among varieties" (p. 343). Macro-policy goals have directly impacted language acquisition (i. e. standardization of Bahasa Indonesia in Indonesian schools, Papua New Guinea Pidgin as the national language, and a change in the distribution of function in Tanzania, Israel, Yugoslavia, and the USSR). 
Macro-implementation decisions may be made at the national level (i.e. teacher training programs, development of curriculum standards and requirements, and official language use). These decisions may affect "who learns which languages for which purposes" (Tollefson, 1981, p. 344) and vary depending on the language policies in different countries.

Micro-policy goals and micro-implementation decisions.

Macro-implementation decisions at the national level are specified for local communities and individuals. Tollefson (1981) calls these specifications micro-policy goals. Once micro-policy goals are established, particular implementation actions and microimplementation decisions must be conducted by those who have direct contact with learners, the targets of macro-policy goals.

Tollefson (1981) focuses on those intermediate planned variables that often affect the learner's level of unplanned variables: input, learner, learning, learned, and learner variables which are interrelated in SLA process.

\section{Cultural knowledge and communicative competence.}

Tollefson views language learning is from the teachinglearning aspect, but Kramsch examines it more from a perspective of language use in social and cultural contexts. According to Kramsch (1987), if students learn a language for language use in social context, they have a three-fold task: structuring social encounters, negotiating context and meaning, and learning spoken language. 
The first two are important strategies for learners' survival in natural settings in the L2. The last strategy has not been a focus in most textbooks that emphasize writing rather than speaking. Spoken language, which is more culturally determined, involves time and non-verbal communication, body language, turn-taking, turn yielding, intonation, etc.

Kramsch (1987) emphasizes the difference of social competence between the native language environment and the target language environment and between natural situations and school settings. Therefore, language learners must be taught the functional uses of the foreign language with its linguistic properties according to different social contexts.

Focusing on the importance of natural interaction, Kramsch (1983) clarifies three levels for creating and negotiating meaning:

1. identical level - ideas; 2 . interpersonal level - interpersonal behavior; and 3. textual level - language rules. She explains the nature of meanings -- they are not fixed by definitions in the dictionary or by the intentions of the speaker or writer. Brumfit (1980) concludes Kramsch's perspectives of language from negotiation of meaning: "Language is not a set of definable and prearranged tokens but a process of linguistic and cultural negotiation of meaning" (p. 1).

\section{Learner Variables}

Many researchers have examined learner variables in various 
SLA studies in psychology and linguistics. The variables have been classified or combined differently. The following have been frequently discussed: age, gender, aptitude, motivation, attitude, personality factors (anxiety, tolerance of ambiguity, risk-taking, selfesteem, empathy, etc.), cognitive and learning styles, linguistic and sociocultural backgrounds, and language learning strategies (Reiss, 1981; Brown, 1987; Crookes \& Schmidt, 1989; Ely, 1989; Oxford, Lavine, \& Crookall, 1989; Parry \& Stansfield, 1990; Skehan, 1991; Gardner \& McIntyre, 1992; Scarcella \& Oxford, 1992; Oxford \& Ehrman, 1993). Besides those learner variables, researchers include situational variables (Tollefson, 1981; Scarcella \& Oxford, 1992), social and cultural environment (Kramsch, 1986, 1987, 1993; Wenden, 1987), or learning environment (LoCastro, 1994) -- all factors that combine to affect language learning.

\section{Language Learning Strategies (LLSs)}

In the 1970s, some SLA researchers shifted their focus from a study of language teaching methods to research on individual variation in language learning (Brown, 1987, Magnan, 1990), because they recognized success of certain learners regardless of teaching methods. Such recognition guided them to focus on individual behaviors in an effort to help unsuccessful learners by identifying language learning strategies (LLSs) that good learners employed (Rubin, 1975; Reiss, 1981).

One of the earliest studies by Rubin (1975), which focused on 
"good language learners," is considered an important milestone in investigation of LLSs. She detailed characteristics of "good language learners" from the aspect of maximum intelligibility: (1) willing and accurate guesser, (2) strong desire to communicate, (3) less selfconscious, not afraid of making mistakes to communicate, (4) attention to form, constantly analyzing, categorizing, and synthesizing, (5) practice and pursuit of opportunities to use the language, (6) monitoring one's own speech and speech of others, and (7) attention to meaning, the context of the speech acts, and the rules of speaking.

Reiss (1981) compared self-report LLSs and techniques between successful "A" and unsuccessful "C/D" students. Using Rubin's seven LLSs, Reiss found that successful students reported more specific LLSs for their learning tasks than did unsuccessful students. For instance, the most helpful LLSs for memory for successful students are: remembering by rhyming, association (mental pictures), and mnemonic devices. Unsuccessful students, on the other hand, seem to prefer remembering by association and repetition, and making up lists and reading them aloud.

According to Reiss' study, successful students are more conscious of and active in their learning, for example, speaking to themselves when walking or jogging, getting more opportunities to speak their target language, and trying to answer questions mentally in class. Unsuccessful students, on the other hand, are less conscious of their learning because they are more likely to study 
with someone and translate everything into their native language. These findings suggest the importance of learner autonomy (Wenden, 1991). Wenden discusses how to help learners learn how to learn. Successful learners have a high level of awareness of learning and obtain certain LLSs and attitudes. They can use these skills and knowledge confidently, flexibly, and appropriately on their own.

Rubin and Reiss established the foundation for LLS research of the 1980s and 1990s. Other researchers have defined and classified LLSs in various ways.

The following sections will focus on language learning strategy definitions and classifications.

\section{Language learning strategy definitions.}

LLSs have been investigated in many ways from various aspects during the past two decades; however, the main purpose of the research has been how to make the learning process more successful. The following definitions illustrate perception changes in language learning strategy studies. Rubin refers to LLSs as "the techniques or devices which a learner may use to acquire knowledge" (1975, p. 43). Later, she defines LLSs more precisely as "strategies which contribute to the development of the language system which the learner constructs and affect learning directly" (1987, p. 23).

Bialystok (1978) explains that LLSs are "optional means for 
exploiting available information to improve competence in a second language" (p. 71). Brown (1987) explains that LLSs are "specific methods of approaching a problem or task, modes of operation for achieving a particular end, planned designs for controlling and manipulating certain information" (p. 79). Chamot and Küpper, from a more psychological view, say that LLSs are "techniques which students use to comprehend, store, and remember new information and skills" (1989, p. 13). Similarly, Vann and Abraham (1990) define LLSs as "behavior that learners engage in to learn a second/foreign language" (p. 177).

Oxford defines LLSs as " . . the often-conscious steps or behaviors used by language learners to enhance the acquisition, storage, retention, recall, and use of new information (1990b, p. 439). She most recently defines LLSs by expanding her previous definition in a much simpler way: "specific actions taken by the learner to make learning easier, faster, more enjoyable, more selfdirected, more effective, and more transferable to new situations" (1990a, p. 8). She emphasizes that LLSs play important roles in order to achieve the goal of communicative competence as a whole.

\section{Classifications of language learning strategies.}

As LLSs have been defined differently, so have their classifications. In her initial work, Rubin (1975) did not classify LLSs; however, later she identified six strategies for language learning: (1) clarification/verification (confirmation of understanding, validation 
of production), (2) guessing/inductive inferencing (use of previous knowledge for a specific meaning or rule), (3) deductive reasoning (a problem-solving strategy with general rules), (4) practice (repetition, rehearsal, imitation, attention to detail), (5) memorization (the storage and retrieval process), and (6) monitoring (identification of problems, error correction) (1987, pp. 23-25). Rubin's classification does not contain a group of communication strategies, yet each of her six strategies listed above contains them.

Tarone (1981) classifies LLSs from a communication focus into three groups: production strategy; learning strategy; and communication strategy. She emphasizes communication strategies that compensate for linguistic deficiency in attempts to communicate, which is not included in Rubin's classification. Communication strategies include paraphrase (approximation, word coinage, circumlocution); borrowing (literal translation, language switch); appeal for assistance; mime; and avoidance (topic avoidance, message abandonment).

In 1985, O'Malley, Chamot, Stewner-Manzanares, Russo, and Küpper categorized strategies into three major groups: metacognitive (planning, self monitoring, evaluation of self and others); cognitive (grouping, contextualization, inferencing, translation, note taking, etc.); and socioaffective (cooperation and questions for clarification). Although their classifications include only three strategy groups, they are much more refined and cover a greater number of 
strategies for language learning than do those included by Rubin and Tarone.

From both language learning and use aspects, Cohen (1995) classifies LLSs into two categorizations: language learning strategies and language use strategies. Language learning strategies help learners to improve their knowledge in a target language; whereas, language use strategies involve both language performance strategies and communication strategies in the target language.

\section{Oxford's Language Learning Strategy System}

In 1989, Oxford developed a strategy system based on previous researchers' efforts. She identified 62 strategies and classified them into six groups: memory; cognitive; comprehension; metacognitive; affective; and social strategies (see Appendix A). Each of the six is subcategorized and these six are further classified into two groups: direct (memory, cognitive, and compensation) and indirect (metacognitive, affective, and social) strategies as shown in Figure 2. Oxford also has a visual explanation of interrelationships between direct and indirect strategies and among the six strategy groups as shown in Figure 3:

Oxford's strategy system differs from the strategy classifications that have been done previously in that it is much more comprehensive and elaborated with more extensive details. Oxford (1990a) includes details that relate individual strategies and strategy groups with the four language skills (listening, reading, 


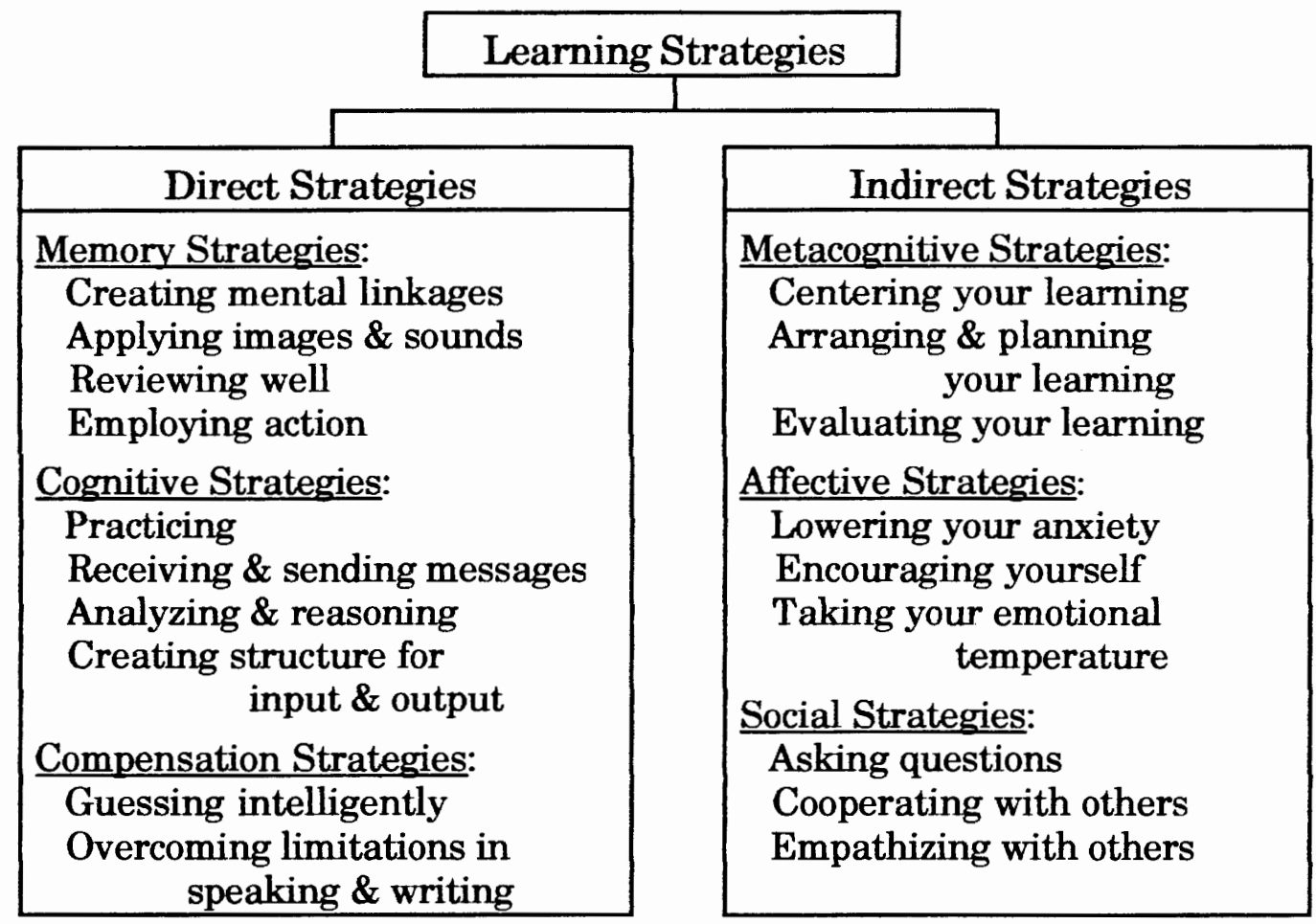

Figure 2. Diagram of the Strategy System: Overview (Oxford, 1990a, p. 16).

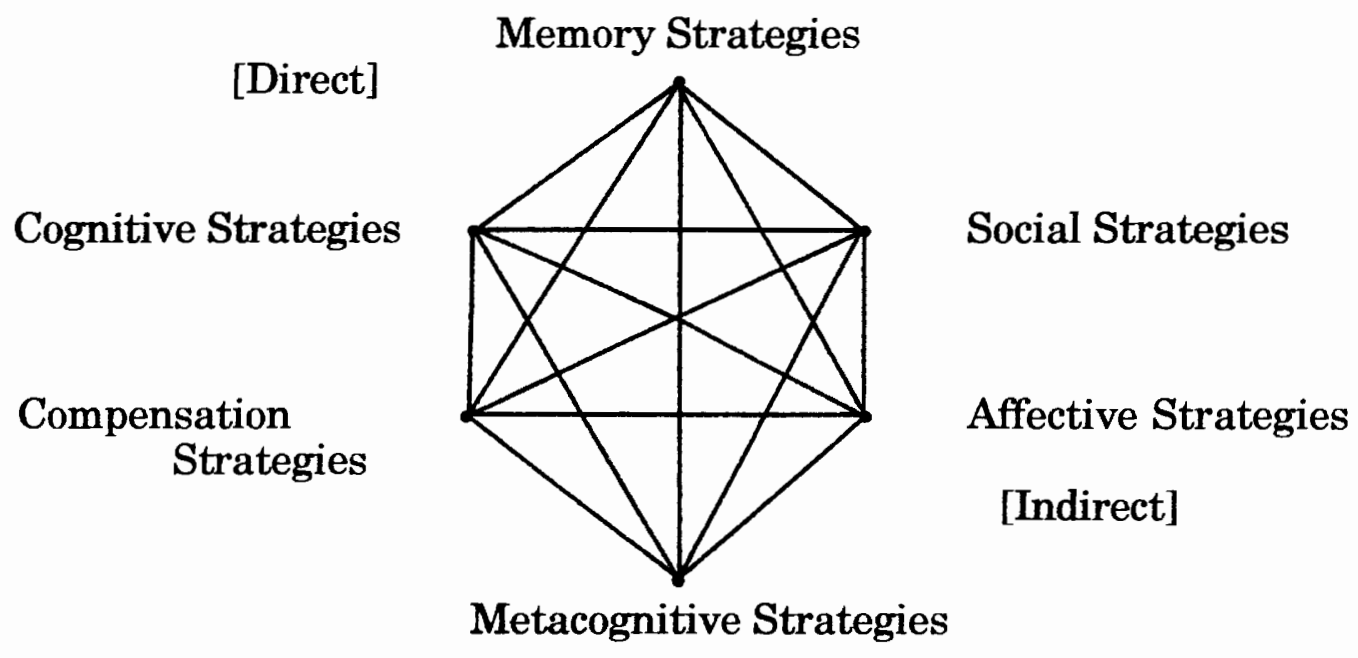

Figure 3. Interrelationships between direct and indirect strategies and among the six strategy groups (Oxford, 1990a, p. 15). 
speaking, and writing) in simple terms.

Oxford emphasizes the relationship between both language learning and teaching. She insists teachers must be aware of how learners learn and process what is taught, and learners need to know how they learn and what they know about learning. Both teachers and learners focus more easily on direct strategies than on indirect strategies; however, they also have to pay equal attention to indirect strategies.

\section{Oxford's Strategy Inventory for Language Learning.}

In 1989, Oxford designed the Strategy Inventory for Language Learning (SILL) to help learners understand how they learn another language (see Appendix B). Knowing what strategies learners employ is the key to becoming better language learners who are responsible for and autonomous in their own learning (Wenden, 1985). This relates to the affective, motivational, and social-cultural factors in learners' attitudes and motivation for second language acquisition (Ellis, 1985). Oxford (1990a) has since created two different versions of the SILL: Version 5.1 for English speakers learning a new language; and Version 7.0 for speakers of other languages learning English (ESL/EFL).

\section{SILL as a self-report survey.}

As an elicitation technique, surveys are most commonly and widely used in educational research (Nunan, 1992). However, Cohen (1995) warns about questionable validity of self-report data collection: 
"Questionnaire items are more likely to elicit learners' beliefs about what they do, rather than what they actually do" (p. 3). LoCastro (1994) also discusses the importance of qualitative data to accompany quantitative data like the SILL in order to reach certain conclusions of LLSs. Analysis of data should consist of various factors including learner characteristics and educational background.

\section{Japanese Learners' Characteristics}

A number of researchers and scholars both in Japan and in the Western countries have discussed characteristics of Japanese society, culture, and people (see Benedict, 1947; De Vos, 1985; Doi, 1974, 1981; Lebra \& Lebra, 1986; Nakane, 1970; Rohlen, 1974; Smith, 1983). For instance, Nakane (1970), introduces vertical personal relations from an anthropological view, and from a psychological aspect, Doi (1981) discusses Japanese attitudes and behavior.

There are several crucial features of Japanese people and culture that have been discussed. Wa, amae, honne, and tatemae are often talked about by scholars, and they are translated into the following English terms: "harmony within the group," "dependency needs," "inner feelings," and "overt or public behavior" respectively. Although these English specific words do not provide a full picture of Japanese reality (Ono, 1976), they are helpful in discussing Japanese university students' language learning strategies in this study. 
Wa (harmony within the group), amae (dependency needs), honne (inner feelings), and tetemae (overt or public behavior) are interrelated, and they describe Japanese people, society, and culture. Referring to foreign language education policy in Japan, Koike, Professor of Economics at Keio University, and Tanaka, Professor of English at Nanzan University point to seven factors that help to explain Japan and Japanese people: (1) an island country, isolated geographic situation with overpopulation, insufficient natural resources, and four seasons, (2) group consciousness, (3) communication discrepancies between honne and tatemae, (4) hierarchical social structure, (5) structure of the Japanese language, (6) high level of the educational system, and (7) the traditional translation method (1995).

Group consciousness of the Japanese social psychology and communication discrepancies as well as English education in Japan are the focus of the following section.

\section{Group consciousness of the Japanese social psychology.}

Existence as an island nation with dense population, limited natural resources, and Buddhist and Confucianist teaching is the significant factor for the Japanese social character. Japanese have practiced how to keep wa (harmony within the group) that is based on the ideology of Confucianism from China (Umehara, 1987). Honna and Hoffer (1989) point to the Japanese concept of wa as follows: 
Conformism fosters a great sense of oneness shared by all the members in the same group. ... A member who deviates from the group norms or disturbs the group consensus may have to take the risk of being excluded from the group. In fact, there is a Japanese saying which goes, "The nail that stands up will be pounded down." (p. 122) According to this concept, wa clearly implies "groupism" and "antiindividualism"

Smith's explanation of Japanese group consciousness is similar to that of Honna and Hoffer:

The individual cannot act out of self-interest that violates the consensus of the group. The usual alternatives are to suppress personal desires, to modify one's preferences in acceptable ways, or to leave the group altogether. . . But leaving the group, . . . is a step not easily taken in Japan, for the simple reason of the clear boundaries that surround the group and set it off from all the others. (1983, p. 90)

Smith (1983) also outlines when the personality of a Japanese individual in the group develops as follows: "The personality of the individual is essentially completely formed during the process of early childhood socialization within the family" (p. 70)

Murase (1983) supports the process of early childhood socialization by explaining "Japanese children are not encouraged from an early age to emphasize individual independence or autonomy. They are brought up in a more or less 'interdependent' 
or amae culture" (p. 319). According to Doi (1981), amae, "a key concept for understanding Japanese personality structure" (p. 21), represents "the true essence of Japanese psychology" (p. 26). Amae indicates "helplessness and the desire to be loved" (Doi, 1981, p. 22) and "dependency needs" (Doi, 1974, p. 309).

\section{Communication discrepancies.}

Shimazu (1984) explains discrepancies between honne (inner feelings) and tatemae (overt or public behavior) that often disguise the truth or confuse people from other cultures, especially those who are from Western cultures. She notes "Japanese cultural patterns" that form their value system and behaviors, and "Japanese students are not usually encouraged to analyze things, much less to think on their own" (p. 19). Rohlen (1983) similarly discusses Japanese high school classes:

... of children sitting still and listening to their teacher, of accumulating facts but having little opportunity to discuss them, of having views, but not needing to express them, of possibly resenting the authority of teachers, but of leaning not to challenge it. (p. 246).

What Rohlen points to is passivity of Japanese students who have received dependence training. Dependence training is defined as "child-rearing practices that foster compliance in the performance of assigned tasks and dependence on the family, rather than reliance 
on oneself" (Haviland, 1990, p. 130). It helps produces obedient and passive individuals (Haviland, 1990).

As long as Japanese students remain in Japan, they will not have problems. However, when they put themselves in a completely foreign environment in which independence training is favored, they will experience difficulty. Being less autonomous, Japanese learners feel uncomfortable to express their opinions, and it is especially difficult for them to say something opposite or different from others. Their prior school experience in Japan influences how they perceive their behavior which is appropriate in the classroom (Kramsch, 1985). An appropriate classroom behavior in the L1 would disagree with an appropriate classroom behavior in the L2. If there is a big difference between them, it can be problematic; not only teachers but also Japanese students experience difficulty, and they often do not understand why.

\section{English Education in Japan}

\section{Brief history of English teaching in Japan.}

English has been taught for more than 100 years in Japan. According to Ike (1995), in 1881 the Ministry of Education declared compulsory English classes for the middle school curriculum as a basic requirement for general education. English was essential for higher education. However, few students had opportunities to speak English, so students learned English by a reading method which prepared them to accept willingly the grammar-translation method. 
Although the aural-oral approach and the audio-lingual approach were introduced in the 1920s and in the 1950s and 1960s, the examination-oriented teaching of English did not allow the aural-oral and the audio-lingual approaches to replace the grammar translation method (Ike, 1995; Koike \& Tanaka, 1995). The traditional grammar-translation method still predominates in secondary English education in Japan even though the communicative approach is perceived favorably. Reischauer (1988) defines the English education in Japan as "Classes in English tended to become preparations for the passing of examinations, not the learning of a living tongue" (p. 389).

The English education policy and system.

The main purpose of English education in Japan is not for communication, but for the high school and college entrance examinations (Berns, 1990). Therefore, macro-policy goals, "the aims of plans formulated by authorities with responsibility for the national community" (Tollefson, 1981, p. 343) are part of the decision making hierarchy and planning levels in English education in Japan.

Macro-policy goals, which depend on the system in which the status of English changes, affect macro-implementation decisions on how the policies are carried out. Because of the educational competitiveness, schools and cram (preparatory) schools have to work together closely. Their main concern is how to prepare students for entrance examinations, so the status of English is 
almost totally exam-oriented. The purpose of English teaching is much narrower in Japan than in other countries, such as India, Singapore, and Indonesia, where English functions as the communication means at school and in business and political fields.

Because of such macro-policy goals, micro-policy goals, which involve "the nature of evaluation instruments and curriculum" (Tollefson, 1981, p. 344), control micro-implementation decisions. Input variables, what to teach and how to teach it, are limited under this system. English education is affected by outside classroom variables, and teachers seem to have no control over the system. If Japanese teachers of English try to control input variables, they may become "trouble makers" in a society that prefers the status quo to conflict or a transformational view. This explains the difficulty and slowness of English educational change in Japan and also reflects the group consciousness discussed above.

What and how teachers want to teach may differ from what and how the authorities want them to teach. This discourages not only teachers but also learners from exploring the language-culture connection and developing the ability to use English for communicative purposes (Berns, 1990). LoCastro (1994), who teaches at a university in Japan, discusses learning strategies that depend on the purpose for learning language, which is also influenced by the learning context. With a better understanding of Japanese students in the Japanese educational environment, she brings up crucial points which imply the grammar-translation 
method in Japan. Such a teaching method, firmly rooted in Japanese cultural patterns and the social system of values, reflects the educational context.

English classes in Japanese secondary schools are teachercentered, and cooperative or interactive learning is rarely observed in classes. The number of students in a class, about 40 at junior and senior high schools, is too many for teachers and learners to interact well. Furthermore, junior and senior high school teachers are occupied in preparing their students for entrance examinations, and they usually do not have the opportunity or time to recognize each learner's individual characteristics, learning style and strategies. They try to satisfy curricular goals or microimplementation goals set by the Ministry of Education. However, a nationwide study by the Committee for Research on English Language Teaching in the Japanese School System resulted in a negative recognition of current English education (Koike \& Tanaka, 1995).

This study was the largest and most valuable survey for understanding the revisions of TEFL (Teaching English as a Foreign Language) policies. A series of questionnaires was completed between 1983 and 1990 by TEFL administrators, English teachers at various levels from primary-school to college and university as well as college and university graduates. According to findings, more than half of those surveyed recognized the ineffectiveness of current English instruction in Japan (Koike \& Tanaka, 1995). 


\section{Japanese students' motivation.}

English is one of the required subjects in Japanese secondary schools, and learners need to do well in English classes in order to pass university entrance examinations. Academic success equips them for upward mobility in society. Additionally, they receive extrinsic pressures, such as expectations from families, schools, and society. The anticipation of reward and the learner's motivation can be strong (see Gardner \& MacIntyre, 1991, 1992).

Japanese students have more instrumental motivation for foreign language learning influenced by the social system of values and beliefs embedded in the Japanese educational context (LoCastro, 1994). Grammatical accuracy and formal training in instructional settings are more important than interaction. Traditional foreign language education excludes dynamics of human interactions, conceptual notional development, and discourse aptitude (Kramsch, 1986). 


\section{CHAPTER III}

\section{METHODS}

This study examines how differently Japanese learners of English think they employ their language learning strategies (LLSs) in different learning environments: Japan as an EFL (English as a Foreign Language) situation and the United States as an ESL (English as a Second Language) situation. This chapter discusses subjects, instruments, and collection of data.

\section{Description of Subjects}

A group of forty-three Japanese students from Otemae College in Japan participated in this study. They were in the Otemae program at Portland State University (PSU), a "tailor-made," more culture learning-oriented program. All of the students are females, 20 or 21 years of age, majoring in American and British Literature. Their English learning backgrounds are similar, eight years in a formal education system before coming to Portland. Some of them have had experience in foreign countries, yet their stay was for a very short period of time; therefore, this was their first time to live in the English environment for six to nine months. Their prior exposure to the English environment was limited, so their individual experience of studying English is considered equal to that of those who had never been abroad.

The students can be divided into two groups: 28 students in a 
6-month short-term program (ST Group), and 15 in a 9-month longterm program (LT Group). All of the 43 students were enrolled in the spring and summer terms, and $\mathbf{1 5}$ of them continued to stay in the fall term. During the spring term, they took Experiential Learning, American Culture, and Coastal Ecology classes for the Otemae program. During the summer, the Otemae program combined with the ESL program at PSU, and students were enrolled in two Beginning ESL classes (Reading, Writing, Speaking, or Listening), and American Short Stories, Children Literature, Drama, Film Study, or Film and Video Production. In the fall term, fifteen students in the 9-month program were enrolled in the Otemae program with ESL classes and an undergraduate class: Oregon's Environmental Resources, Introduction to American Education, First Aid, Journal Writing, or Introduction to Architecture.

They not only took classes together, but also they lived together. They lived in apartments off-campus; four students shared an apartment, so they spoke mainly Japanese with their roommates. The program offered students a host-family arrangement, and they visited their host families on weekends.

\section{Design of the Survey Instruments}

A combination of self-assessment questionnaires, dialogue journals, and card-ranking activities was employed in this study.

The self-assessment questionnaires (the SILL) were administered at different times during the learning period for 
identification of their language learning strategies (LLSs) in their native language environment (L1) and in their target language environment (L2).

Dialogue journals more insightfully indicate students' perceptions of themselves and language learning than do the questionnaires. Students wrote comments about their experiences and feelings in dialogue journals when they voluntarily attended a weekly tutoring session offered by the Otemae program and the researcher at PSU.

Dialogue journals as methods of self-report allow learners to record their positive and negative experiences related to language learning, feelings, concerns, problems, questions, etc. (Oxford, 1990a). Keeping journals is a useful learning strategy which leads learners to better awareness of language learning and varieties of LLSs.

The results of the card ranking activity exhibited students' perceptions of learning experience in the $\mathrm{L} 2$, which may explain the results of the questionnaires and relate to their comments in dialogue journals.

\section{Questionnaires: the SILL.}

The SILL, designed by Oxford (1990a), has been used for both research and classroom practice. The SILL, a type of self-report survey, has various versions, such as Version 5.1 for English speakers learning a new language, and Version 7.0 for students of 
English as a second or foreign language. Oxford considers the SILL as a structured survey with standardized categories that illustrate learning strategy tendencies, preferences, and difficulties of individual learners and/or a particular group of learners. Because of its nature as a structured instrument, the SILL, translated into many various languages, has been extensively used in the world. It is considered the best and most comprehensive instrument for a language learning strategy inventory (Brown, 1994) because it contains so many different LLSs. The earlier versions displayed high validity and reliability by being field-tested extensively: the internal consistency reliability is .96 by Cronbach's alpha, and the content validity is .95 (Nyikos \& Oxford, 1993).

\section{The SILL Version 7.0 ESL/EFL.}

Due to the subjects' English proficiency, the SILL (Version 7.0 ESL/EFL) was translated into Japanese by the researcher (see Appendix C). The Japanese translation was translated back into English by a fluently bilingual Japanese graduate student. Her English translation was compared with the original language in the SILL by a native speaker of English in order to eliminate misinterpretation with the Japanese version, and any necessary changes were made.

The SILL consists of 50 statements (questions), categorized into six parts that present the six strategy groups, discussed in Chapter II. As direct strategies, the SILL includes 29 statements: 
9 for memory strategies (Part A), 14 for cognitive strategies (Part B), and 6 for compensation strategies (Part C). As indirect strategies, the SILL contains 21 statements: 9 for metacognitive strategies (Part D), 6 for affective strategies (Part E), and 6 for social strategies (Part F). Here are some examples from each part (Oxford, 1990a, pp. 293-296):

Part A: "I physically act out new English words."

Part B: "I read for pleasure in English."

Part C: "I read English without looking up every new word." Part D: "I pay attention when someone is speaking English." Part E: "I try to relax whenever I feel afraid of using English."

Part F: "I ask English speakers to correct me when I talk."

Students are asked to choose one from the following Likertscale which indicates their attitude or behavior to each of the $\mathbf{5 0}$ statements and write it on the worksheet:

1. Never or almost never true of me (very rarely)

2. Generally not true of me (less than half the time)

3. Somewhat true of me (about half the time)

4. Generally true of me (more than half the time)

5. Always or almost always true of me (almost always)

Oxford (1990a) suggests how to interpret the mean score results of each part as follows (p. 300) : 
High Always or almost always used

4.5 to 5.0

Usually used

3.5 to 4.4

Medium

Sometimes used

2.5 to 3.4

Low

Generally not used

1.5 to 2.4

Never or almost never used

1.0 to 1.4

The averages for each part tell learners which groups of LLSs they use more frequently for learning English.

The 50 statements in the SILL with worksheet and profile of results are found in Appendix B.

\section{Collection of Data}

Elicitation techniques (self- assessment questionnaires and card ranking activity) and introspection (dialogue journals) were used to gather data. The self-assessment questionnaires are used for the quantitative analysis, dialogue journals are for the qualitative analysis, and card ranking activities are for both quantitative and qualitative analysis of this particular group of Japanese college students.

\section{Three administrations of the SILL.}

The SILL was administered three times at four-month intervals. Forty-one students in both ST and LT Groups participated in SILL \#1 as a part of the Otemae program at PSU; they were asked to look back at their learning strategies of English that they thought they had employed in the L1. On SILL \#2, 40 students in both groups thought about their LLSs that they were using in the 
L2. SILL \#3 was given to students in both ST and LT Groups eight months after SILL \#1, but at that time the ST Group students were in Japan, the L1; whereas the LT Group students were in Portland, the L2. The SILL was mailed to 27 ST Group students in Japan, and 17 students responded. Fourteen LT Group students also took the SILL in Portland. Table I shows three administrations of the SILL as well as two groups of subjects in the L1 and the L2.

\section{TABLE I}

THREE ADMINISTRATIONS OF THE SILL AND TWO GROUPS OF SUBJECTS

\begin{tabular}{|c|c|c|c|}
\hline & SILL \#1 & SILL \#2 & SILL \#3 \\
\hline $\begin{array}{c}\text { ST Group } \\
{[N=28]}\end{array}$ & LLSs in L1 & LLSs in L2 & $\begin{array}{c}\text { LLSs in L1 } \\
{[N=15]}\end{array}$ \\
\cline { 1 - 1 } \cline { 4 - 5 } $\begin{array}{c}\text { LT Group } \\
{[N=15]}\end{array}$ & {$[N=41]$} & {$[N=40]$} & $\begin{array}{c}\text { LLSs in L2 } \\
{[N=14]}\end{array}$ \\
\hline
\end{tabular}

\section{Dialogue journals.}

Weekly tutoring sessions were offered by the Otemae program and the researcher in order to support the students both academically and non-academically. Student participation was completely voluntary; therefore, student attendance varied weekly, as did the data collection of students' dialogue journals. The total number of students who came to the 21 sessions from the spring through the fall terms is 166 . Table II shows a breakdown of the three terms according to the number of 2-hour sessions, the number 
of students per session, and the pertinent detailed information for each respective term.

TABLE II

NUMBERS OF TUTORING SESSIONS AND

PARTICIPANTS PER SESSION

\begin{tabular}{ccccl}
\hline $\begin{array}{c}\text { Term } \\
\text { 1995 } \\
\text { [Number of } \\
\text { students] }\end{array}$ & $\begin{array}{c}\text { Number of } \\
\text { sessions }\end{array}$ & $\begin{array}{c}\text { Number of } \\
\text { participants } \\
\text { per session }\end{array}$ & $\begin{array}{c}\text { Total } \\
\text { number of } \\
\text { participants }\end{array}$ & Type of program \\
\hline $\begin{array}{c}\text { Spring } \\
{[43]}\end{array}$ & 6 & $2-23$ & 103 & $\begin{array}{l}\text { Only Otemae } \\
\text { program }\end{array}$ \\
\hline $\begin{array}{c}\text { Summer } \\
{[43]}\end{array}$ & 8 & $2-9$ & 40 & $\begin{array}{l}\text { Otemae program } \\
\text { with ESL program }\end{array}$ \\
\hline $\begin{array}{l}\text { Fall } \\
{[15]}\end{array}$ & 7 & $2-6$ & 23 & $\begin{array}{l}\text { Otemae program } \\
\text { with ESL and } \\
\text { undergraduate } \\
\text { program }\end{array}$ \\
\hline
\end{tabular}

Students who attended the sessions kept a dialogue journal of whatever they wanted to share anonymously with the tutor and the other students in the session. These dialogue journals consisted of their academic and non-academic concerns and questions, language learning experiences, experiences with their host families, and personal matters. Although the principle language used for the dialogue journals was Japanese, a few students wrote in English, and others made bilingual entries. Because students' identification (ID) numbers were used instead of names in the journals, the students felt more secure and comfortable to express their concerns and/or 
questions. The ID numbers were also served to track the journals of a given student.

Student comments were used as discussion topics for the following session. The tutor (researcher) introduced student feelings, concerns, and questions during the session, but no one, except those who actually wrote them, knew whose comments were shared. What students wrote in their dialogue journals was used by the researcher in order to prepare for the card ranking activity, which will be explained later.

As an extension to the dialogue journals, what was discussed in informal conferences, gatherings, and correspondence between the students and the tutor has become additional data for this study. The tutor and students had informal conferences and gatherings whenever necessary while students were studying at PSU. Some students wanted to discuss their personal problems in person with the tutor after the tutoring session. Other students telephoned the tutor to discuss their class assignments, to ask for advice and help, or to ask questions about grammar and LLSs. Others sent notes to the tutor, expressing their feelings. The tutor is currently corresponding with several students even after their return to Japan. They have expressed their positive and negative experiences in Japan after living and taking classes in the United States.

\section{Card ranking activity.}

The comments written by the students when the program was 
in progress were reviewed during weekly tutoring sessions, but at that time the students did not compare the negativity or positivity of their current or prior comments. After the program was completed, the students were asked to rank their comments in groups of negative and positive experiences.

The card ranking activity was designed for an insightful analysis of their comments in dialogue journals in addition to categorizing them into groups and calculating numbers of comments in different categories. The card ranking activity provided this study with the retrospective view of the students' experiences in the L2 with a measurement of negativity and positivity.

When SILL \#3 was administered, 14 LT Group students completed the card ranking activity related to their experiences in the L2. SILL \#3 was given to them just before their departure from the United States after nine months of participation in the program. The LT Group students used 40 cards which contained comments from the dialogue journals of the Otemae students. With SILL \#3, the researcher also sent the materials of the activity accompanied with detailed explanations of the procedures to the ST Group students in Japan (see Appendix D). Seventeen of the 28 ST Group students responded. These ST Group students had been in the L1 for four months after returning to Japan.

Forty items on the cards.

The cards contained student generated information in 
Japanese from the weekly tutoring sessions. The total number of dialogue journal cards for three terms was 148; they contained 444 comments. Table III is a breakdown of the three terms according to the number of dialogue journal cards and the number of comments.

TABLE III

THE NUMBER OF DIALOGUE JOURNALS AND COMMENTS

\begin{tabular}{ccc}
\hline $\begin{array}{c}\text { Term } \\
1995\end{array}$ & $\begin{array}{c}\text { Number of } \\
\text { dialoguejournals }\end{array}$ & $\begin{array}{c}\text { Number of } \\
\text { comments }\end{array}$ \\
\hline Spring & 83 & 235 \\
\hline Summer & 40 & 120 \\
\hline Fall & 23 & 89 \\
\hline
\end{tabular}

The researcher categorized these comments into the following groups: (1) self development; (2) culture related issues;

(3) communication and relationships; (4) expectation and realization;

(5) English learning; and (6) school related issues. These six were divided into 40 sub categorizations and numbered 1 through 40 at random, regardless of the six categories (see Appendix $\mathrm{E}$ for a list of the 40 subcategories).

Here are a few English translation excerpts: "\# 5 gap between expectation and reality of English improvement, "\# 20 communication and relationships with host family," and "\# 26 expressing feelings in English." 
Forty was determined to be the minimum functional number of cards for representation of student comments and manageability for the card ranking activity.

\section{Card ranking activity procedure.}

Given a set of $\mathbf{4 0}$ cards with numbers, each student was asked to choose ten cards out of the 40 which represented her negative experiences in the L2. Students ranked the ten cards from the most negative to the least. The student then wrote the card numbers on the worksheet, from 1 , the most negative, to 10 , the least negative. After putting the 10 chosen cards back with the other cards, the students chose 10 cards again, but this time they ranked them according to their positive experiences in the L2. The process was repeated for positive student experiences with an explanation that it was possible to choose the same card(s) again. The students then ranked the 10 cards and recorded the card numbers on the worksheet, from 1 , the most positive, to 10 , the least positive. 
CHAPTER IV

\section{THE STRATEGY INVENTORY OF LANGUAGE LEARNING (SILL) RESULTS AND DISCUSSION}

This chapter presents quantitative results from three administrations of the SILL. The next chapter will discuss these statistical results with qualitative data: the students' dialogue journals and the card ranking activity.

\section{Three Administrations of the SILL}

Otemae student perceptions of their language learning strategies (LLSs) were statistically analyzed by comparing the results of three SILLs taken at 4-month intervals. The first SILL presents the Otemae student perceptions of English LLSs in their native language environment (L1), Japan, and the second SILL demonstrates how the Otemae students characterize their English LLSs in their target language environment (L2), the United States. The third SILL consists of two groups: (1) LLSs of students in the short-term group (ST Group), and (2) LLSs of students in the longterm group (LT Group).

Two different statistical analyses of the data were completed as follows:

(1) Comparison of LLSs (LT and ST Groups) between the SILLs \# 1 (L1) and \# 2 (L2) 
(2) Comparison of LLSs (LT Group) between the SILLs \# 2 (L2) and \# 3 (L2)

(3) Comparison of LLSs (ST Group) between the SILLs \#2 (L2) and \#3 (L1)

With the results of these statistical analyses, the following hypotheses will be investigated:

(1) SILL \#2 (LLSs in the L2, ST and LT Groups) would show an increase in median scores from SILL \#1 (LLSs in the L1).

(2) SILL \#3 (LLSs in the L2, LT Group) would continue to show an increase in median scores from SILL \#2 (LLSs in the L2).

(3) SILL \#3 (LLSs in the L1, ST Group) would show a decrease in median scores from SILL \#2 (LLSs in the L2).

Figure 4 illustrates relationships between three administrations of the SILL in different language environments and three hypotheses.

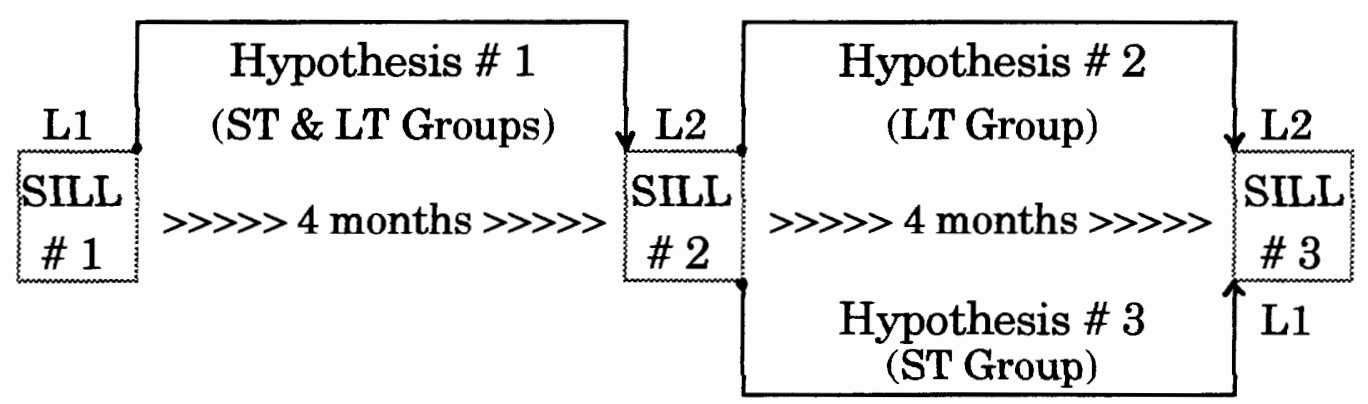

Figure 4. Relationships between the SILLs and the hypotheses

The Wilcoxon matched-pairs signed-ranks test.

Since the ordinal data presentation of the SILLs, the Likertscale ranks from 1 to 5 (from "Never or almost never true of me" 
to "Always or almost always true of me"), parametric procedures are inappropriate. Therefore, a nonparametric test, the Wilcoxon matched-pairs signed-ranks test was chosen for investigating significant differences between the paired median scores of the SILLs.

In addition, the Bonferroni test was applied in order to adjust the observed level of significance according to the number of comparisons. "The more comparisons you [researchers] make, the larger the difference between pairs of means must be for a multiple comparison procedure to find it significant" (Norusís, 1992, p. 241). There was a matched pair of median scores for each of the six strategies in SILLs \#1 and \#2, \#2 and \#3, and \#1 and \#3. Therefore, the initial assigned level of significance, .05 , was adjusted by dividing by 3 for these three pairs. Fifty individual questions in the SILLs were compared twice by pair-matching the median scores of SILLs $\# 1$ and \#2, and \#2 and \#3; therefore, .05 was divided by 2 . The total adjusted level of significance levels for the paired median scores of each strategies was .0167. The adjusted level of significance for questions in parts A through $\mathrm{F}$ was .0250 .

\section{Hypothesis \# 1}

The comparison between SILLs \#1 and \#2 examines whether or not LLSs in the L1 would change in the L2. In this comparison, ST Group and LT Group were combined as one group. They shared the same conditions (i.e. gender, age, length of time in the L2, 
enrollment in the Otemae program, and language and cultural background), so internal validity was not threatened.

Table IV shows comparisons of all median scores between SILLs \#1 (L1) and \#2 (L2). The median score of SILL \#2 increased from 3.0 to 4.0 in total. This was a significant difference, with a $P$ value less than .0001 . Therefore, the first hypothesis, "SILL \#2 (LLSs in the L2, ST and LT Groups) would show an increase in median scores from SILL \#1 (LLSs in the L1)" was supported.

\section{TABLE IV}

WILCOXON MATCHED-PAIRS SIGNED-RANKS TEST:

COMPARISONS OF ALL MEDIAN SCORES

BETWEEN SILLs \# 1 (L1) AND \# 2 (L2)

[ST \& LT GROUPS: $\mathrm{N}=40$ ]

\begin{tabular}{lccc}
\hline & $\begin{array}{c}\text { SHL \# 1 } \\
\text { Median }\end{array}$ & $\begin{array}{c}\text { SHL \# 2 } \\
\text { Median }\end{array}$ & $\begin{array}{c}\text { 2-tailed } \\
\text { P value }\end{array}$ \\
\hline \multicolumn{1}{c}{ TOTAL } & 3.0 & 4.0 & $<.0001^{*}$ \\
\hline [A] Memory & 3.0 & 3.0 & $.0115^{*}$ \\
[B] Cognitive & 3.0 & 4.0 & $<.0001^{*}$ \\
[C] Compensation & 3.5 & 4.5 & $<.0001^{*}$ \\
[D] Metacognitive & 3.0 & 4.0 & .0203 \\
[E] Affective & 2.5 & 3.5 & $.0008^{*}$ \\
[F] Social & 2.0 & 4.0 & $<.0001^{*}$ \\
\hline
\end{tabular}

* = Statistically Significant at $\mathrm{P}=<.0167$

1: Never or almost never true of me

2: Usually not true of me

3: Somewhat true of me

5: Always or almost always true of me

4: Usually true of me 
The students' LLSs in the L1 did change after four months of learning experiences in the L2. As shown in Table IV, median scores on five of the six strategies increased significantly; and they revealed a significant difference except Metacognitive Strategies $(P=.0203)$. Memory Strategies showed no difference in the median score, yet exhibited a significant difference overall $(\mathrm{P}=.0115)$.

Memory and Affective Strategies also exhibit statistical significance. Although Memory Strategies had no change in the median scores between SILLs \#1 and \#2, the numbers of positive differences and negative differences are 22 and 6 , respectively, including 12 with no differences. Conversely, Metacognitive Strategies showed a difference in the median scores, but it was not statistically significant. This is because of the number of ties, 18, with no differences even with 16 positive differences and 6 negative differences.

These six strategies $\mathrm{A}$ through $\mathrm{F}$ include 6 to 14 questions, and the following section will investigate which questions in the six strategies exhibited the significant difference.

\section{Part A: Memory Strategies.}

Memory Strategies, one of the direct strategies, help learners to arrange ". . things in order, make associations, and reviewing ..." (Oxford, 1990a, p. 39).

Although the median scores of Part A stayed the same at 3.0 for both SILLs, a statistically significant difference was revealed. 
Nine questions in Part A were examined individually, and the following five showed significant difference between the two administrations of SILL:

Q 2. "I use new English words in a sentence so I can remember them."

Q 4. "I remember a new English word by making a mental picture of a situation in which the word might be used."

Q 6 ."I use flashcards to remember new English words."

Q 7. "I physically act out new English words."

Q 9. "I remember new English words or phrases by remembering their location on the page, on the board, or on a street sign."

All of these questions relate to strategies of memorizing vocabulary. Table $\mathrm{V}$ exhibits that median scores on each of the questions changed by 1.0: four increased from 3.0 to 4.0 or from 2.0 to 3.0, but the remaining one, Q6, decreased from 3.0 to 2.0.

$\mathrm{Q} 2, \mathrm{Q} 4, \mathrm{Q} 7$, and $\mathrm{Q} 9$ relate to word memorization techniques that involve mental linkages and semantic mapping or physical responses. On the other hand, Q 6 deals with learning solely by rote memorization. The students used flashcards for remembering words in the L1, but in the L2 they found it ineffective. In order to understand vocabulary in a deeper and broader way, by the second administration of the SILL they had learned the importance of understanding the context in which vocabulary is used. This explains 
the increase of the median scores of Q2, Q4, Q7, and Q9. In addition, such an understanding may have contributed to the decrease of the Q6 median score. Q6 was one of the four of a total of fifty questions that displayed a decrease in median scores in the comparison between SILLs \#1 and \#2 (see Appendix F for more details).

\begin{tabular}{|c|c|c|c|}
\hline \multicolumn{4}{|c|}{$\begin{array}{c}\text { TABLE V } \\
\text { WILCOXON MATCHED-PAIRS SIGNED-RANKS TEST } \\
\text { MEDIAN SCORE COMPARISONS OF MEMORY STRATEG } \\
\text { BETWEEN SILLS \# } 1 \text { [L1] AND \# } 2 \text { [L2] } \\
\text { [ST \& LT GROUPS, N=40] }\end{array}$} \\
\hline & \multicolumn{2}{|c|}{ Median Score } & \multirow[b]{2}{*}{$P$ value } \\
\hline & SILL \#1 & SILL \#2 & \\
\hline Q 2 & 3.0 & 4.0 & $.0042^{*}$ \\
\hline Q 4 & 3.0 & 4.0 &. .004 $^{*}$ \\
\hline Q 6 & 3.0 & 2.0 & $.0163^{*}$ \\
\hline Q 7 & 2.0 & 3.0 & $.0006^{*}$ \\
\hline Q 9 & 3.0 & 4.0 & $.0190^{*}$ \\
\hline & & \multicolumn{2}{|c|}{$* \mathrm{P}$ value $=<.025$} \\
\hline $\begin{array}{l}\text { 1: Never or almos } \\
\text { 3: Somewhat true } \\
\text { 5: Always or almo }\end{array}$ & $\begin{array}{l}\text { true of } \\
\text { ays true }\end{array}$ & \multicolumn{2}{|c|}{$\begin{array}{l}\text { 2: Usually not true of me } \\
\text { 4: Usually true of me }\end{array}$} \\
\hline
\end{tabular}

Part B: Cognitive Strategies.

Cognitive Strategies are the most widely used LLSs. These include practicing, receiving and sending messages, analyzing and reasoning, and creating structure for input and output (Oxford, 1990a). 
As the following list shows, there were nine of the 14 questions in part B, except Q16, whose median scores increased, but all of these nine questions revealed a significant difference:

Q 11. "I try to talk like native English speakers."

Q 12. "I practice the sounds of English."

Q 13. "I use the English words I know in different ways."

Q 14. "I start conversations in English."

Q 15. "I watch English language TV shows spoken in English or go to movies spoken in English."

Q 16. "I read for pleasure in English."

Q 17. "I write notes, messages, letters, or reports in English."

Q 18. "I first skim an English passage (read over the passage quickly) then go back and read carefully."

Q 22. "I try not to translate word-for-word."

Table VI summarizes median score comparisons of Cognitive Strategies between SILLs \#1 and \#2. As shown in the table, all of these questions exhibited a significant difference between SILL \#1 and \#2, yet the $P$ values of $Q 14$ and Q17 were lower than the others. The students had to employ these strategies for succeeding in the $\mathrm{L} 2$ both academically and non-academically. Their median scores, 2.0 in SILL \#1, indicate that they had had few opportunities to use these strategies in the L1 because the Japanese language is 
dominant, and the methodology of English education has been grammar/translation.

TABLE VI

WILCOXON MATCHED-PAIRS SIGNED-RANKS TEST:

MEDIAN SCORE COMPARISONS OF COGNITIVE STRATEGIES

BETWEEN SILLs \# 1 [L1] AND \# 2 [L2]

[ST \& LT GROUPS, $\mathrm{N}=40$ ]

\begin{tabular}{cccc} 
& \multicolumn{2}{c}{ Median Score } & \\
& SILL \#1 & SILL \#2 & P value \\
\hline Q 11 & 3.0 & 4.0 & $.0003^{*}$ \\
Q 12 & 3.0 & 4.0 & $.0032^{*}$ \\
Q 13 & 2.0 & 3.0 & $.0025^{*}$ \\
Q 14 & 2.0 & 3.0 & $<.0001^{*}$ \\
Q 15 & 4.0 & 5.0 & $.0062^{*}$ \\
Q 16 & 3.0 & 3.0 & $.0224^{*}$ \\
Q 17 & 2.0 & 3.0 & $<.0001^{*}$ \\
Q 18 & 4.0 & 4.0 & $.0055^{*}$ \\
Q 22 & 3.0 & 4.0 & $.0002 *$ \\
\hline & & \multicolumn{2}{c}{$*$ P value $=<.025$}
\end{tabular}

1: Never or almost never true of me

3: Somewhat true of me

5: Always or almost always true of me

2: Usually not true of me

4: Usually true of me

The nature of Japanese English education may explain a change in the students' strategies for reading. As Table VI shows, the differences on $\mathrm{Q} 16, \mathrm{Q} 18$, and Q22 were all significant. They indicate that the students' reading strategies changed in the L2 even though the median scores of Q16 and Q18 were the same. Q22 
indicates the students' new practice of English reading without translating. After four months in the L2, the students seemed to understand that word-for-word translation is not a useful strategy.

Regarding strategies for speaking, Q11 indicates the students' inferior feelings as non-native speakers toward their English abilities, especially the pronunciation skills. They wanted to pronounce English like native speakers, even though ultimate attainment of second language (i.e. accent-free, native-like performance) is nearly impossible because of their age and linguistic background (Krashen, Long, \& Scarcella, 1979).

Q11 connects with Q12 (the practice of English sounds) and Q15 (TV shows and movies in English). The students obtained more opportunities for these strategies in the L2. They used these strategies in the $\mathrm{L} 1$ before coming to the $\mathrm{L} 2$, and can continue using them after returning to the L1 so as to retain their English abilities.

Q13 explains change in the students' views of English learning. The students broadened and deepened their understanding of language learning by experiencing English words and expressions in the L2. They discovered other meanings for vocabulary they had already learned. This indicates their focus on communication in English rather than solely on English learning in an academic environment in the L1.

Cognitive Strategies consist of strategies that learners can employ more easily and/or that they have to use in the L2 (i.e. Q14, Q17, and Q22). Others are strategies that learners can attempt in 
the $\mathrm{L} 1$ (i.e. Q12, 13, 15, 16, and 18). Strategies in the SILLs contain two types of strategies: strategies more useful in the L2 and those more likely to be used in the L1. Some of the strategies must be used more than others by learners, depending on where they learn English. This implies that there is a potential for a culturally biased factor in the SILL. This issue will be discussed in Chapter VI under Limitations of the Study.

\section{Part C: Compensation Strategies.}

Compensation Strategies are strategies for compensating for missing knowledge in communication. Part $\mathrm{C}$ was the highest in median scores in both SILLs \#1 and \#2 (3.5 and 4.5 respectively). The following four questions out of a total of six were significantly different:

Q 26. "I make up new words if I do not know the right ones in English."

Q 27. "I read English without looking up every new word."

Q 28. "I try to guess what the other person will say next in English."

Q 29. "If I can't think of an English word, I use a word or phrase that means the same thing."

Table VII summarizes median score comparisons of Compensation Strategies between SILLs \#1 and \#2. According to the results, the students' experiences in the $\mathrm{L} 2$ indicated the students were becoming more capable and autonomous in communication. 
TABLE VII

WILCOXON MATCHED-PAIRS SIGNED-RANKS TEST:

MEDIAN SCORE COMPARISONS OF COMPENSATION

STRATEGIES BETWEEN SILLs \# 1 [L1] AND \# 2 [L2]

[ST \& LT GROUPS, N=40]

\begin{tabular}{lccc} 
& \multicolumn{3}{c}{ Median Score } \\
& SHLL \#1 & SILL \#2 & P value \\
\hline Q 26 & 3.0 & 4.0 & $.0174^{*}$ \\
Q 27 & 3.0 & 4.0 & $.0085^{*}$ \\
Q 28 & 3.0 & 4.0 & $<.0001^{*}$ \\
Q 29 & 4.0 & 5.0 & $.0064^{*}$ \\
\hline & & \multicolumn{2}{c}{ *P value $=<.025$} \\
1: Never or almost never true of me & \multicolumn{2}{l}{ 2: Usually not true of me } \\
3: Somewhat true of me \\
5: Always or almost always true of me
\end{tabular}

Improvement in cultural, linguistic, and communicative competence allowed the students to fill missing knowledge more effectively by guessing better. As shown in Table VII, Q26, Q28, and Q29 illustrate such improvement, particularly Q28 at a P value less than .0001 . These three strategies are associated closely with verbal communication. The students had little time to look for vocabulary or expressions while conversing, so they had to apply available strategies immediately. Living and studying in the L2 motivated and encouraged the students to use English for communication more actively. Communication with their host families reinforced the students' communication skills, giving the students a strong impact through immediate feedback. 
The students' experiences also raised their level of tolerance of ambiguity since they had to rely on guessing. The students began to understand the necessity of guessing when they realized that translation was not always reliable in the L2. At the beginning of the spring term, the students believed that they had to understand everything they heard or read in order to comprehend. However, they were encouraged by their teachers and tutor to guess even though they did not know or understand each word.

Q 27 (reading English without looking up every new word) represents a change of reading strategy of the students. Forty per cent of the students selected 4 and 5 from the Likert-scale in SILL \#1, whereas approximately $70 \%$ did so in SILL \#2. This change also corresponds with the change with Q 22 in Part B (trying not to translate word-for-word). Dictionaries functioned as "crutches" to many of the students; they relied on them frequently. The tutor introduced the use of an English dictionary instead of an EnglishJapanese dictionary. She also explained vocabulary in cultural linguistic context of each language.

\section{Part D: Metacognitive Strategies.}

Metacognitive Strategies are " . . a actions which go beyond purely cognitive devices" (Oxford, 1990a, p. 136), and they provide learners with assistance to organize the learning process. The importance of metacognitive strategies is emphasized when learners 
come to understand their learning by analyzing their mistakes and their own progress in the language learning process.

Three of the nine questions in Part $\mathrm{D}$ displayed a significant difference as follows:

Q 30. "I try to find as many ways as I can to use my English."

Q 35. "I look for people I can talk to in English."

Q 38. "I think about my progress in learning English."

Table VIII exhibits median score comparisons of Metacognitive Strategies between SILLs \#1 and \#2. Although only three strategies in Part D revealed a significant difference, they are the strategies the students were able to employ more effectively in the L2 where there were more opportunities to use English than in the L1.

\section{TABLE VIII}

WILCOXON MATCHED-PAIRS SIGNED-RANKS TEST: MEDIAN SCORE COMPARISONS OF METACOGNITIVE STRATEGIES BETWEEN SILLs \# 1 [L1] AND \# 2 [L2] [ST \& LT GROUPS, $\mathrm{N}=40$ ]

\begin{tabular}{cccc} 
& \multicolumn{3}{c}{ Median Score } \\
& SILL \#1 & SILL \#2 & P value \\
\hline Q 30 & 3.0 & 4.0 & $.0002^{*}$ \\
Q 35 & 2.0 & 4.0 & $.0001^{*}$ \\
Q 38 & 4.0 & 4.5 & $.0012^{*}$ \\
\hline
\end{tabular}

$* \mathrm{P}$ value $=<.025$

1: Never or almost never true of me

3: Somewhat true of me

2: Usually not true of me

4: Usually true of me

5: Always or almost always true of me 
As shown in Table VIII, Q30 (trying to find as many ways as possible to use English) and Q35 (looking for people to talk to in English) display a significant difference. Increases in the total percentage of students who chose a response from 3 through 5 (Likert-scale) in the SILLs can be explained by the increased opportunity for English use in the L2 (i.e. Q 30: 51.3\% $\rightarrow 97.4 \%$, and $Q 35: 30.8 \% \rightarrow 84.6 \%$ ). These increases indicate that the students' behavior altered when they changed their language environment from the L1 to the L2.

Regarding the progress in learning English, Q 38 was one of the students' major concerns. The students were curious about how much their English would improve during their stay between six and nine months, and they seemed to have unrealistic expectations at the beginning. The total percentage of responses of 3,4 , and 5 (Likert-scale) increased from $71.8 \%$ on SILL \#1 to $94.9 \%$ on SILL \#2 . The students became increasingly aware of the gap between their expectations and reality. However, this does not explain whether the students interpreted this awareness positively or negatively. In the next chapter, dialogue journals will provide their insights relating to their realization of a gap between their expectations and reality.

\section{Part E: Affective Strategies.}

Controlling learners' emotions and attitudes are important keys to success in language learning. 
Table IX shows median score comparisons of Affective Strategies between SILLs \#1 and \#2. The following three questions exhibited a significant difference at a $P$ value of less than .025 :

Q 39. "I try to relax whenever I feel afraid of using English."

Q 40. "I encourage myself to speak English even when I am afraid of making a mistake."

$\mathrm{Q}$ 41. "I give myself a reward or treat when I do well in English."

TABLE IX

WILCOXON MATCHED-PAIRS SIGNED-RANKS TEST: MEDIAN SCORE COMPARISONS OF AFFECTIVE STRATEGIES BETWEEN SILLs \# 1 [L1] AND \# 2 [L2] [ST \& LT GROUPS, $\mathrm{N}=40$ ]

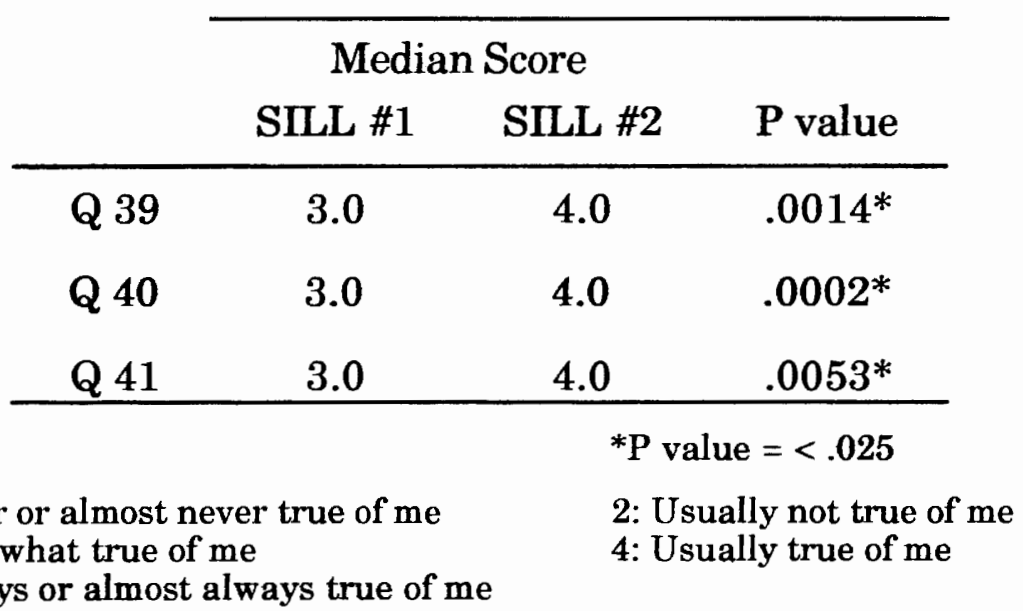

The increased use of these three strategies: Q39, Q40, and Q41 suggests that the students encouraged themselves and managed their emotions. They realized their own negative feelings toward language learning and accepted them. The students considered 
these negative feelings as a part of the challenge of the language learning process (i.e. Metacognitive Strategies). Journal entries indicate that their perceptions of mistakes and errors changed from negative to positive in that they began to monitor their mistakes and learn from them.

Emotions became a mode of experience during the learning process. The students laughed and cried during their stay in the L2. They ran the emotional gamut: happiness, inspiration, frustration, and nervousness.

Those who participated in the weekly tutoring sessions shared their feelings with other classmates and their tutor. Although Q 43 (writing a language learning diary) did not change in the median score of 2.0, the students who attended the tutoring sessions actually recorded their feelings in their dialogue journals. Similarly, Q44 (discussing feelings with someone else) did not exhibit a significant difference $(\mathrm{P}=.0333)$, but the students came to the tutoring sessions to share their feelings together with their classmates and tutor. The above are examples that the students' actual behavior did not always reflect their perceptions of LLSs.

Their emotional learning experiences deepened their understanding of language learning and allowed them to think about themselves as well. Related to self observation, "self-improvement" emerged as one of the most important issues to the students and will be discussed in the next chapter. 


\section{Part F: Social Strategies.}

Oxford (1990a) claims that language, a form of social behavior, is communication between and among people. It is important to recognize and employ social strategies that allow learners to communicate well and get along well with other people, not only those who are from the same culture, but also from different cultures. Learners must cultivate cultural understanding with empathy.

Part $\mathrm{F}$ is the only part resulting in a significant difference for all of the questions. Table $\mathrm{X}$ exhibits median score comparisons of Social Strategies between SILLs \#1 and \#2. As shown in the table, the observed significant levels range from less than .0001 to .0136 . Here are all six of the questions:

Q 45. "If I do not understand something in English, I ask the other person to slow down or say it again."

Q 46. "I ask English speakers to correct me when I talk."

Q 47. "I practice English with other students."

Q 48. "I ask for help from English speakers."

Q 49. "I ask questions in English."

Q 50. "I try to learn about the culture of English speakers."

As Table X shows, the median scores of $Q 48$ (asking for help from English speakers) and Q 49 (asking questions in English) increased from 2.0 to 4.0. They are the only two in which there were no negative differences of median scores from SILL \#1 to SILL \#2. 
TABLE $X$

WILCOXON MATCHED-PAIRS SIGNED-RANKS TEST

MEDIAN SCORE COMPARISONS OF SOCIAL STRATEGIES

BETWEEN SILLs \# 1 [L1] AND \# 2 [L2]

[ST \& LT GROUPS, $\mathrm{N}=40$ ]

\begin{tabular}{cccc}
\multicolumn{4}{c}{ Median Score } \\
\cline { 2 - 4 } & SILL \#1 & SILL \#2 & P value \\
\hline Q 45 & 4.0 & 4.0 & $.0013^{*}$ \\
Q 46 & 2.0 & 3.0 & $.0001^{*}$ \\
Q 47 & 2.0 & 3.0 & $.0058^{*}$ \\
Q 48 & 2.0 & 4.0 & $<.0001^{*}$ \\
Q 49 & 2.0 & 4.0 & $<.0001^{*}$ \\
Q 50 & 4.0 & 4.0 & $.0136^{*}$ \\
\hline \multicolumn{4}{c}{ *P value $=<.025$} \\
2: Usually not true of me \\
r or almost never true of me
\end{tabular}

Although these six questions displayed a significant difference, there is not necessarily an explanation of the LLS change. A positive significant difference indicates a change in students' perceptions of LLSs even though the change may not be a conscious one. Q48 and Q49 were essential strategies for success in the L2. The students sought help from people by asking questions in English.

People in this context include English speakers as well as those who speak other languages. Q 47 (practicing English with other students) is a good example of this. The students practiced English with other students who came from Korea, Thailand, and other Asian countries. Although the students had difficulties 
communicating in English as a common language, their interest and desire to communicate overcame their difficulties. The students also practiced English with their friends and classmates from Otemae College and cultivated their friendships and relationships. All of their experiences helped them grow by understanding who they were with a better cultural awareness of "self" and "others."

Q46 (asking English speakers for corrections of one's mistakes) demonstrates the students' motivation for improvement of not only linguistic skills but also communication and social skills. These skills led the students to become better English users who understand cultural differences in a positive way and relate to Q50 (learning about the target culture).

Related to Compensation Strategies, these social strategies helped the students improve their communicative skills and knowledge of the target culture as well as their own culture. Q50, deals with cultural learning. It also explains an improved understanding and a broader perspective of language learning with implication of self-improvement. Although the median score for Q50 was the same in SILL \#1 and \#2, a significant difference was observed

Hypothesis \#1 investigated a comparison of SILL \#1 (L1) and SILL \#2 (L2), and a significant difference was displayed. This indicates an increase of perceived use of LLS use during the fourmonth English learning experiences in the L2. 
Hypothesis \# 2

Hypothesis \#2 examined whether or not there would be any increase between the median scores in SILLs \#2 and \#3 of LT Group. This was accomplished by the administration of the third SILL four months later in the L2.

Table XI exhibits comparisons of all median scores between SILLs \#2 and \#3 (LT Group).

TABLE XI

WILCOXON MATCHED-PAIRS SIGNED-RANKS TEST: COMPARISONS OF ALL MEDIAN SCORES BETWEEN SILLs \# 2 (L2) AND \# 3 (L2) [LT GROUP: $\mathrm{N}=14$ ]

\begin{tabular}{lccc}
\hline & $\begin{array}{c}\text { SILL \# 2 } \\
\text { [L2] } \\
\text { Median }\end{array}$ & $\begin{array}{c}\text { SHL \# 3 } \\
\text { [L2] } \\
\text { Median }\end{array}$ & $\begin{array}{c}\text { 2-tailed } \\
\text { P value }\end{array}$ \\
\hline \multicolumn{1}{c}{ TOTAL } & 4.0 & 4.0 & .4631 \\
\hline [A] Memory & 3.0 & 3.0 & .4631 \\
[B] Cognitive & 4.0 & 4.0 & .2026 \\
[C] Compensation & 4.5 & 5.0 & .1536 \\
[D] Metacognitive & 3.5 & 4.0 & .7353 \\
[E] Affective & 4.0 & 4.0 & .1536 \\
[F] Social & 4.0 & 4.0 & .4990 \\
\hline \multicolumn{4}{c}{ * Statistically Significant at $\mathrm{P}=<.0167$}
\end{tabular}

1: Never or almost never true of me

2: Usually not true of me

3: Somewhat true of me

4: Usually true of me

5: Always or almost always true of me 
As shown in Table XI, there was no increase in the total median scores between SILLs \#2 and \#3. However, there were two increases in median scores of Compensation and Metacognitive Strategies, yet they were not significantly different. The other median scores stayed the same. The LT Group students continued to keep their LLSs that had been attained during the first term in the L2, and they showed more frequency of LLS use in Compensation and Metacognitive Strategies. From all of these, hypothesis \#2 was not fully supported.

In the fall term, LT Group students took one undergraduate class in addition to the Otemae program and ESL classes. The increases in median scores of Compensation and Metacognitive Strategies can be explained in the students' ability to make more accurate guesses and overcome limitations in their English skills by planning, monitoring, and analyzing their learning. The students seemed to become more autonomous in their learning.

Figure 5 illustrates comparisons among three administrations of the SILL (LT Group).

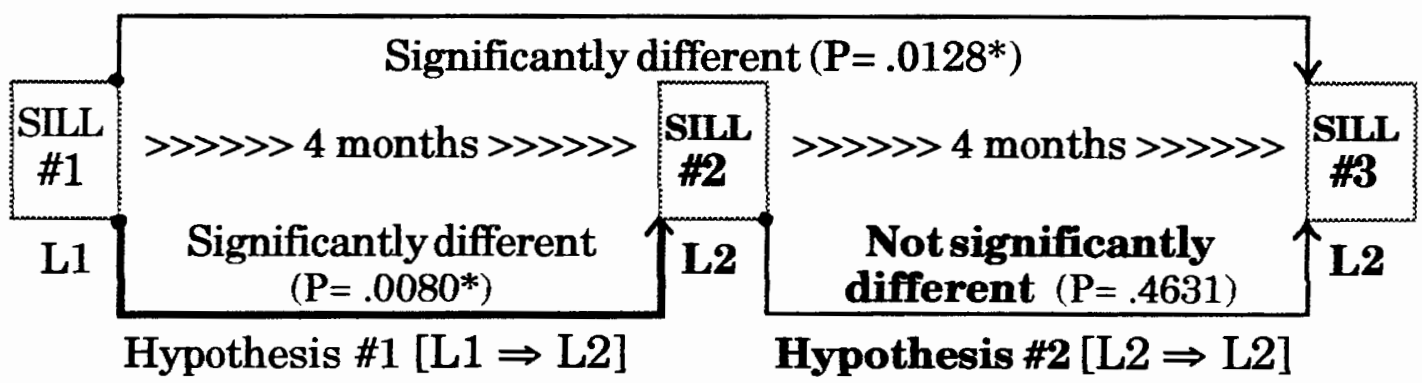

Figure 5. Diagram of hypotheses and three administration of the SILLs (LT Group, n=14) 
All of the comparisons suggest that both changes in context and length of time in the L2 affected the students' LLSs, yet it is unclear which of these influenced the change in their LLSs most.

\section{Hypothesis \# 3}

Hypothesis \#3 investigated a comparison of SILLs \#2 (L2) and \#3 (L1) of 15 ST Group students. The overall median scores of both LT and ST Groups of SILL \#2 $(n=40)$ increased from SILL \#1 significantly when the language learning environment changed from the L1 to the L2 (see Table IV). Therefore, a decrease of median scores was expected when ST Group students took part in SILL \#3 in the L1 four months after they returned to Japan. (In Table XII, only 15 students out of 28 in ST Group who took both SILLs \#2 and \#3 were included.)

Table XII summarizes comparisons of all median scores between SILLs \#2 and \#3 (ST Group). As shown in the table, hypothesis \#3 was supported; there was a decrease in the total median score from SILL \#2 to SILL \#3. Even though half of the six groups showed a decrease in median scores from 4.0 to 3.0, comparisons of median scores between SILLs \#2 and \#3 demonstrated no significant difference. Figure 6 summarizes comparisons among three administrations of the SILLs (ST Group).

Two direct strategies (Cognitive and Compensation) and one indirect strategy (Social) were reported with less frequency of LLS use four months after 15 ST group students returned to the L1. 
TABLE XII

WILCOXON MATCHED-PAIRS SIGNED-RANKS TEST:

COMPARISONS OF ALL MEDIAN SCORES

BETWEEN SILLs \# 2 (L2) AND \# 3 (L1)

[ST GROUP: $\mathrm{N}=15$ ]

\begin{tabular}{|c|c|c|c|}
\hline & $\begin{array}{c}\text { SHL \# } 2 \\
\text { [L2] } \\
\text { Median }\end{array}$ & $\begin{array}{c}\text { SHL \# } 3 \\
\text { [L1] } \\
\text { Median }\end{array}$ & $\begin{array}{l}2 \text {-tailed } \\
P \text { value }\end{array}$ \\
\hline TOTAL & 4.0 & $\mathbf{3 . 0}$ & .3139 \\
\hline [A] Memory & 3.0 & 3.0 & .9528 \\
\hline [B] Cognitive & 4.0 & 3.0 & .7989 \\
\hline [C] Compensation & 4.0 & 3.0 & .0499 \\
\hline [D] Metacognitive & 3.0 & 3.0 & .7671 \\
\hline [E] Affective & 3.0 & 3.0 & .2094 \\
\hline [F] Social & 4.0 & 3.0 & .0231 \\
\hline
\end{tabular}

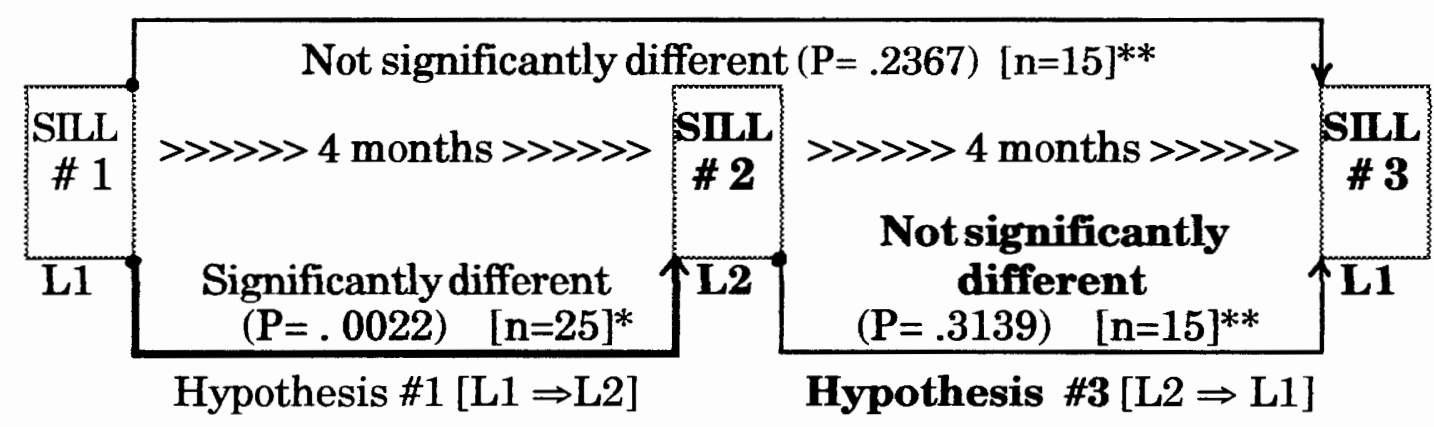

* The comparison between SILLs \#1 and \#2 was done on the basis of 25 students out of 28 in the ST Group rather than 15.

** Seventeen of the 28 students in the ST group responded to SILL \#3 completed in the L1. Two students were excluded due to no response to SILL \#2.

Figure 6. Diagram of hypotheses and three administrations of the SILL (ST Group) 
However, these results failed to explain which influenced the change of their LLSs most, the different contexts or length of time in the L2.

In conclusion, the students in both ST and LT Groups changed their perceptions of their LLSs after four months of English learning in the L2. The LT Group students, who continued their enrollment in the fall term, retained their LLSs during an additional four months. On the other hand, the LLSs of the ST Group students seemed to regress to their initial LLSs during a four-month period in the L1 after leaving the L2. Although the population size was inadequate to represent the LLSs of the ST Group students, the median scores of SILL \#3 appeared similar to those of SILL \#1. The median scores of Affective and Social Strategies increased from 2.0 (SILL \#1) to 3.0 (SILL \#3) even though only Social Strategies disclosed a significant difference with a $P$ value of .0120 .

The researcher may find clues about which different contexts or lengths of time would influence LLSs of the students more if the following were possible:

1. The administration of a SILL \#4 to the LT Group of students four months after their return to the $\mathrm{L} 1$

2. A comparison of the results of SILL \#4 with the data from the ST Group in SILL \#3. 


\section{CHAPTER V}

\section{DIALOGUE JOURNALS AND CARD RANKING ACTIVITY RESULTS AND DISCUSSION}

Three hypotheses were examined by using the results of the SILL presented in the previous chapter. The SILL results directly identify which strategies Otemae students thought they employed in the different language environments. Conversely, their dialogue journals indirectly reflect their perceptions of LLSs and language learning in their native language and target language environments (L1 and L2, respectively). The results of the card ranking activity also explain their perceptions and understanding of their positive and negative learning experiences in the $\mathrm{L} 2$.

This chapter will discuss the results of the SILLs with Otemae students' comments in the dialogue journals and the results of the card ranking activity. The dialogue journals, which were introspective, and the card ranking activity, which was retrospective, will show another aspect of the SILL results.

Dialogue journal comments of the students in both ST and LT Groups were combined for the spring and summer terms just as the SILL results were treated. During the fall term, students in LT Group who continued enrollment kept dialogue journals.

Figure 7 illustrates relationships among three administrations of the SILL, dialogue journals, and the card ranking activity. 

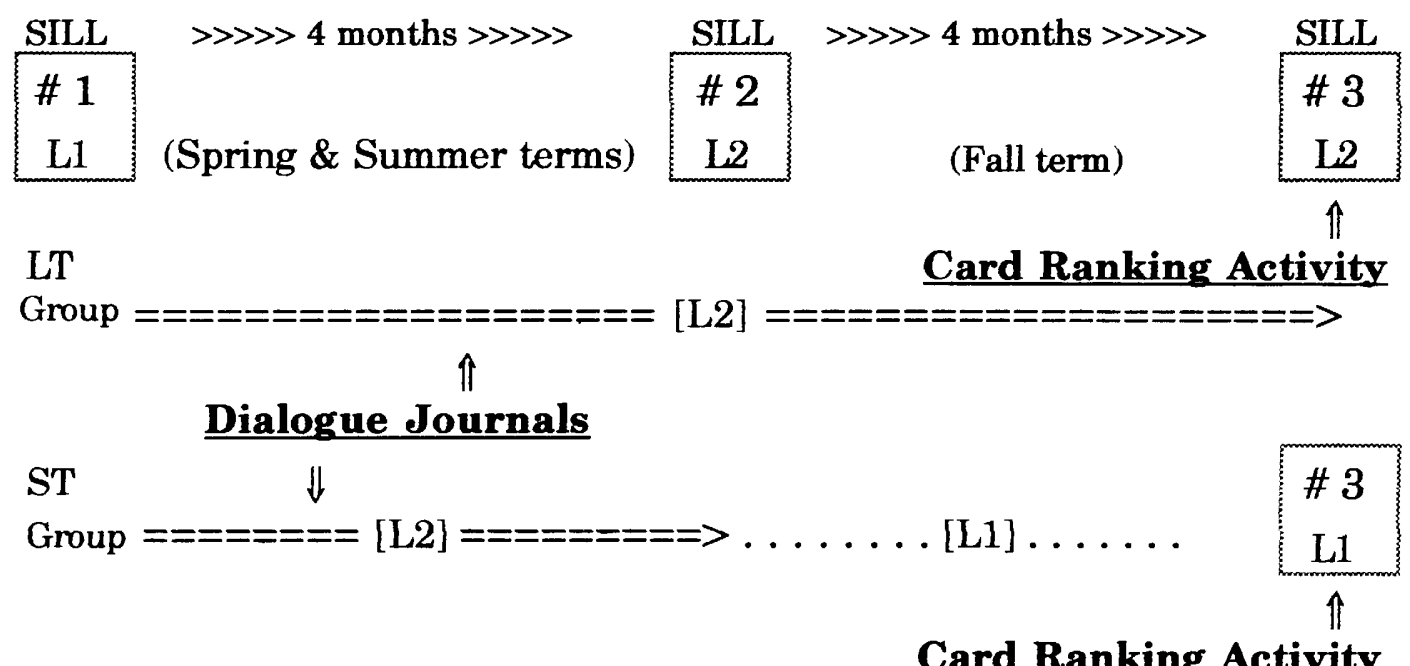

Figure 7. Diagram of the SILLs, Dialogue Journals, and Card Ranking Activity

\section{The Dialogue Journals (Spring and Summer Terms)}

Twenty students out of 43 attended weekly tutoring sessions in the spring term, as did 15 in the summer term. The total numbers of students who came to the sessions were 104 in six sessions in the spring, and 40 in six sessions in the summer. During the spring term, 83 dialogue journals included 235 comments, and in the summer term 40 dialogue journals consisted of 120 comments. These comments were classified into six categories: (1) English learning, (2) communication and relationships, (3) self improvement, (4) school related issues, (5) culture related issues, and (6) expectation and reality. These six categories were broken down into forty subcategories (see Table XIII; Appendices E \& G).

The total numbers of comments and participants can be compared between the two terms. In the summer, the total number 
of times the students came was 40 and their comments added up to 120. Three comments per participant in the summer is not significantly different from 2.2 comments per participant in the spring term. However, this increase can be attributed to their broadened views of learning experiences and/or higher level of awareness of language learning. Such an increase in number of their comments may be associated with the increase in all of the median scores in SILL \#2. The total comparison between the SILLs \#1 and \#2 exhibited a significant difference with a $P$ value of less than .0001 (see Table IV).

The SILL \#1 and \#2 comparison revealed the students' increased use of LLSs in various ways, and it is meaningful to examine the students' comments in their dialogue journals about their language learning experiences. The following table displays a breakdown of the students' comments during the spring and summer terms.

\section{The Students' major issues.}

Table XIII is a breakdown of the spring and summer terms according to the number of comments in six categories. According to the table, the three most frequently mentioned issues were "English learning": 29.3\%; "communication and relationships": 26.8\%; and "self development": 19.2\%. "English learning" was the students' main concern during the spring and summer terms, and it is reflected in other categories, particularly "communication and 
TABLE XIII

COMMENTS IN SIX CATEGORIES

(SPRING SUMMER)

[ST \& LT GROUPS, $\mathrm{N}=40$ ]

\begin{tabular}{lccc}
\hline & $\begin{array}{r}\text { Total } \\
(355)\end{array}$ & $\begin{array}{c}\text { Spring } \\
(235)\end{array}$ & $\begin{array}{c}\text { Summer } \\
(120)\end{array}$ \\
\hline English learning & $\begin{array}{r}\mathbf{2 9 . 3} \% \\
(104)\end{array}$ & $\begin{array}{c}32.4 \% \\
(76)\end{array}$ & $\begin{array}{c}23.3 \% \\
(28)\end{array}$ \\
\hline $\begin{array}{l}\text { Communication and } \\
\text { relationships }\end{array}$ & $\begin{array}{c}26.8 \% \\
(95)\end{array}$ & $\begin{array}{c}\mathbf{3 4 . 5} \\
(81)\end{array}$ & $\begin{array}{c}11.7 \% \\
(14)\end{array}$ \\
\hline Self improvement & $\begin{array}{c}19.2 \% \\
(68)\end{array}$ & $\begin{array}{c}15.7 \% \\
(37)\end{array}$ & $\begin{array}{c}25.8 \% \\
(31)\end{array}$ \\
\hline Culture related issues & $\begin{array}{c}10.1 \% \\
(36)\end{array}$ & $\begin{array}{c}9.4 \% \\
(22)\end{array}$ & $\begin{array}{c}11.7 \% \\
(14)\end{array}$ \\
\hline School related issues & $\begin{array}{c}9.3 \% \\
(33)\end{array}$ & $\begin{array}{c}5.1 \% \\
(12)\end{array}$ & $\begin{array}{c}17.5 \% \\
(21)\end{array}$ \\
\hline Expectation and reality & $\begin{array}{c}5.4 \% \\
(19)\end{array}$ & $\begin{array}{c}3.0 \% \\
(7)\end{array}$ & $\begin{array}{c}10.0 \% \\
(12)\end{array}$ \\
\hline \multicolumn{3}{c}{$(\mathrm{Number}$ of comments $)$}
\end{tabular}

TABLE IV

WILCOXON MATCHED-PAIRED SIGNED-

RANKS TEST: COMPARISON OF ALL MEDIAN SCORES

BETWEEN SILLs \#1 (L1) AND \#2 (L2)

[ST \& LT GROUPS, $\mathrm{N}=40$ ]

\begin{tabular}{lccc}
\hline & $\begin{array}{c}\text { SILL \# 1 } \\
\text { [L1] } \\
\text { Median }\end{array}$ & $\begin{array}{c}\text { SILL \# 2 } \\
\text { [L2] } \\
\text { Median }\end{array}$ & P value \\
\hline \multicolumn{1}{c}{ Total } & 3.0 & 4.0 & $<.0001^{*}$ \\
\hline [A] Memory & 3.0 & 3.0 & $.0115^{*}$ \\
[B] Cognitive & 3.0 & 4.0 & $<.0001^{*}$ \\
[C] Compensation & 3.5 & 4.5 & $<.0001^{*}$ \\
[D] Metacognitive & 3.0 & 4.0 & .0203 \\
[E] Affective & 2.5 & 3.5 & $.0008^{*}$ \\
[F] Social & 2.0 & 4.0 & $<.0001^{*}$ \\
\end{tabular}

* Statistically Significant at $\mathrm{P}=<.0167$

1: Never or almost never true of me

2: Usually not true of me

3: Somewhat true of me

4: Usually true of me

5: Always or almost always true of me 
relationships," "self improvement," and "expectation and reality" (see Appendix G for more details).

"English learning" overlaps these other categories. This agrees with the increase in SILL \#2 in which all of the median scores increased. This provides evidence that the students' concept of English learning in the L1 did change through their four-month experience in the L2; it seemed broadened and deepened. In the following section, the top four subcategories of English learning will be discussed in relation to the results of the SILLs.

\section{Comments on English learning.}

English learning experiences in the L2 influenced the students' understanding of their learning. The students paid more attention to indirect strategies than to direct strategies in the L2. They became more aware of how they were learning, monitoring, evaluating, and analyzing the process of learning rather than what they were learning. This awareness relates to Metacognitive Strategies of the SILL. Even though its $P$ value was nonsignificant statistically, the median score of SILL \#2 increased.

Table XIV shows four leading subcategories of the "English learning" category.

\section{Comments on "grammar skills."}

The students' greatest concern was insufficient grammar skills. As shown in Table XIV, their comments on it form almost a quarter 
TABLE XIV

FOUR LEADING SUBCATEGORIES IN "ENGLISH LEARNING"

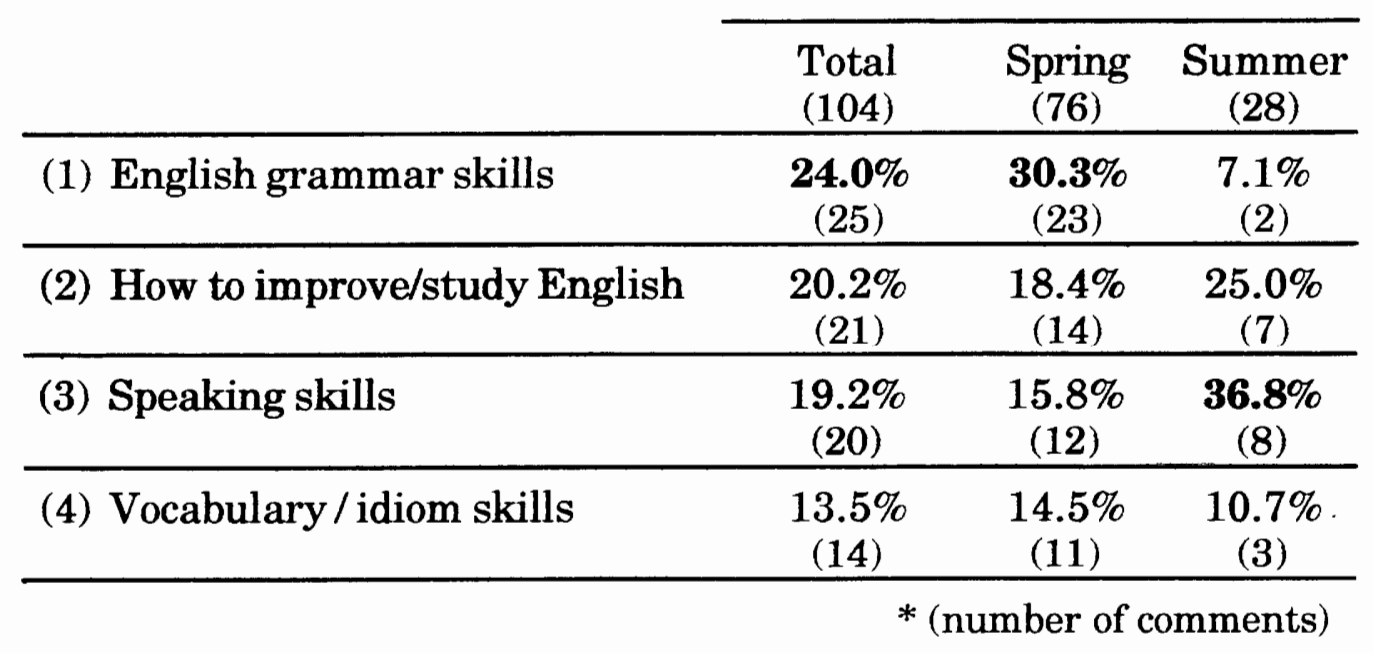

of the total even though they decreased in percentage from $30.3 \%$ in the spring to $7.1 \%$ in the summer. This may mean that the students had a grammar-oriented mindset during the first term in the L2 but changed their view to more communication-oriented English learning in the second term.

Their grammar-oriented focus on English studying is not surprising, given the English education in Japan which focuses more on tests, translation, and grammar. The following comments illustrate this:

Student (S): When I work on listening and reading, I cannot translate English into Japanese from the beginning. When I try to translate from the beginning, I forget what have heard or read in the beginning. Do you think that I will be able to get used to it? In Japan, I was taught to translate backward. (Spring) 
S: Although I know it is better for me not to translate English into Japanese, I can't understand English without translation. (Spring)

S: My grammar has become worse since I came to the U.S. because of the communication-focused instruction here. (Summer)

The last comment is interesting to note because this student's limited view of English learning shows no recognition of a connection between grammar and communication. However, it may be rooted in the English education in the L1, Japan.

Comments on "how to improve/study English."

"How to improve/study English" held a consistent position, around 20\%, in both terms as shown in Table XIV. This implies students' persistent desire for English improvement, which reflects their dissatisfaction and frustration with their English learning and improvement. The following comments illustrate this:

S: Is it all right with listening by just listening? (Spring)

S: Although I want to improve my English, I haven't tried

to work on it. ... I can't be satisfied with this kind of situation. (Summer)

Compensation [C], Metacognitive [D], and Affective [E] Strategies are observed in these two comments: guessing [C: Q24], thinking about the progress in learning English [D: Q28], writing 
down their feelings in their dialogue journals [E: Q43], and talking to someone about their feelings of learning English [E: Q44].

The students' frustration also relates to students' comments in the subcategory, "gap between expectation and reality of English improvement" in the category of "expectation and reality." Although it forms only $3 \%$ of the total, it is interesting to see how the students ranked this subcategory in the card ranking activity which will be discussed later in this chapter.

\section{Comments on "speaking skills."}

As shown in Table XIV, comments on "speaking skills," $15.8 \%$ in the spring term, doubled in the summer, $36.8 \%$. In addition to "grammar skills," the students seemed to pay more attention to "speaking skills" than other skills: "vocabulary/idiom skills" (13.5\% of the total, "listening skills" (10.6\%), "pronunciation" (6.7\%), "reading skills" (4.8\%), and writing skills" (1.0\%). Here are students' comments on speaking skills:

S: I feel frustrated when I cannot easily say what I want to say, so I just keep silent. (Spring)

S: A new class has started. I felt uncomfortable to speak at the beginning, but eventually I have felt comfortable to speak. (Summer)

S: I enjoy speaking English more now, especially when I am with my host family. At the same time I often feel nervous when I speak English. (Summer) 
S: I have recently realized that other classmates in my ESL classes can say what they want to say more smoothly even though their level and mine seem the same. I wish I could do like they do. (Summer)

\section{"Speaking skills" and communication.}

According to the students' comments, "speaking skills" are closely related to communication and relationships, particularly to "communication and relationships with their host families." The subcategory in the "communication and relationships" category forms $37.9 \%$ of the total and is the highest in both spring and summer terms (38.2\% and $35.7 \%$ respectively). The students received a strong impact from interacting with their host families. Communication and relationships with their host families allowed them to broaden their views of language learning with a better cultural understanding and perception of themselves. In order to become aware of other's thoughts and feelings, the students first had to recognize their own thoughts and feelings. This may be one of the important factors for the increase of the median score of Social Strategies in SILL \#2, from 2.0 (usually not true of me) to 4.0 (usually true of me). This also explains the students' comments on "self-improvement," which is associated with Affective Strategies: self-esteem, positive attitudes, motivation, risk-taking, and tolerance of ambiguity. It increased from 2.5 to 3.5. By living and studying in the L2, the students thought about themselves in ways they had 
not thought previously in the L1.

\section{"Speaking skills" and "expressing feelings in English."}

With respect to speaking skills, the students felt frustrated and impatient with their English abilities in expressing their feelings. Although "expressing feelings in English" was fourth in frequency (12.6\%) in the category of the "gap between expectations and reality," this subcategory formed approximately 12 to $14 \%$ consistently over the two terms, which illustrates the students' constant struggles to express what they really meant and wanted to say in English. The following comments on communications and relationships with their host families illustrate the students' feelings:

S: I feel impatient when I cannot express my feelings to my host family. (Spring)

S: My host family says grace and sings a song at the dinner table. I don't know the song, so I just keep silent. Do you [the tutor] think it is all right? (Spring)

S: My host family asked me to go swimming with them, but I did not want to, so I told them that I could not swim on that day. It seemed that I offended them. This shows I cannot express what I really want to communicate or understand what I hear. (Summer)

These comments suggest their confusion and frustration with their English and communication abilities associated with cultural and sociolinguistic differences between Americans and Japanese. 
However, these comments also illustrate the students' strong desire and motivation to communicate and understand their host families as well as to be understood by them. The students, of course, expressed their happy experiences with their host families, which encouraged the students. The following comments were those written in the spring:

S: I felt close to my host family when they understood my jokes.

S: I feel happy that my host family is willing to repeat the same thing over and over again without showing any frustration.

S: When I gave a call to my host family for the first time, my host mother said, "Thank you for your call." This made my day!

Confusion and frustration discouraged the students, and at the same time, they were encouraged by the positive experiences with their host families. They were vulnerable particularly when they started the spring term. Simple incidents made them happy and sad simultaneously. As the terms went by, the students became more relaxed and comfortable in using English by controlling their emotions in a more positive way. This is reflected in the increase of the median score of Affective Strategies from 2.5 (SILL \#1) to 3.5 (SILL \#2). 
There is another factor for the median increase of Affective Strategies. Encouragement and advice from teachers, host families, and other people cannot be ignored. Their support functioned as water and fertilizer for students' healthy growth in different soil. They helped the students reduce their anxiety level and raise their motivation, which led them to success in the language learning process in the L2. The students became more autonomous and responsible for their own learning.

\section{Comments on "vocabulary / idiom skills."}

Closely related to "speaking skills," comments on "vocabulary/idiom skills" placed fourth in the "English learning" category as shown in Table XIV (13.5\% of the total, $14.5 \%$ in the spring, and $10.7 \%$ in the summer). The students' comments on their frustration with speaking skills listed above are associated with their vocabulary and idiom skills. Even when the students recognized vocabulary, that did not mean they could use it in the L2. The following comments illustrate their frustration:

S: My lack of vocabulary frustrates me. I would like to learn idioms. (Spring)

S: I realized my lack of vocabulary when I was reading. I tried to guess the meaning of the vocabulary I don't know from the context, but I couldn't. (Spring)

S: Because of my lack of vocabulary, I often have a hard time to express myself. I have been told to paraphrase what I want 
to say, but it is not easy. How can I deal with my lack of vocabulary when I communicate with people? (Summer)

Related to these comments on vocabulary/idiom skills, median scores of Memory Strategies in the SILLs illustrated the students' effort to remember vocabulary more effectively. Five of the nine questions in Memory Strategies showed change in the median scores between the SILL \#1 and \#2 with a statistically significant difference. Although all of the five are associated with memorizing vocabulary, four median scores of the five increased (i.e. Q2, Q4, Q7, and Q9), and the other decreased (Q6).

Q6 (use of flashcards for word memorization) was the only one whose median score decreased among these five questions $(3.0 \rightarrow 2.0)$. This decrease indicates that the students' realized that rote memorization without considering the contexts in which words were used was not effective. Their realization is indicated in their use of strategies of guessing, mental linkages, and semantic mapping that relate to Part C: Compensation Strategies.

\section{Dialogue Journals of Seven Student (Spring through Fall)}

In the fall term, 15 students continued enrollment at PSU. Seven of these students attended seven weekly tutoring sessions with varying frequency. Their dialogue journal comments totaled 89 in the fall, and a breakdown is shown in Table XV. The purpose of this observation is to demonstrate how these students' perceptions 
and understanding of their language learning experiences in the L2 changed or developed over the three terms.

Comments from their dialogue journals.

Table XV shows a breakdown of the students' comments in six categories from spring to fall terms. The table also exhibits change in the students' perception of LLSs over the three terms.

TABLE XV

DIALOGUE JOURNALS: SLX CATEGORIES OF SEVEN STUDENTS' COMMENTS (SPRING THROUGH FALL)

\begin{tabular}{|c|c|c|c|c|}
\hline Category & $\begin{array}{c}\text { Spring } \\
(76)\end{array}$ & $\begin{array}{c}\text { Summer } \\
(53)\end{array}$ & $\begin{array}{l}\text { Fall } \\
(89) \\
\end{array}$ & $\begin{array}{l}\text { Total } \\
(218)\end{array}$ \\
\hline Self improvement & $\begin{array}{c}18.4 \% \\
(14)\end{array}$ & $\begin{array}{c}37.7 \% \\
(20) \\
\end{array}$ & $\begin{array}{c}31.5 \% \\
(28)\end{array}$ & $\begin{array}{c}28.4 \% \\
(62) \\
\end{array}$ \\
\hline Culture related issues & $\begin{array}{c}11.8 \% \\
(9)\end{array}$ & $\begin{array}{c}13.2 \% \\
(7)\end{array}$ & $\begin{array}{c}22.5 \% \\
(20)\end{array}$ & $\begin{array}{c}16.5 \% \\
(36) \\
\end{array}$ \\
\hline $\begin{array}{l}\text { Expectation and } \\
\text { reality }\end{array}$ & $\begin{array}{c}3.9 \% \\
(3)\end{array}$ & $\begin{array}{c}1.9 \% \\
(1)\end{array}$ & $\begin{array}{c}21.3 \% \\
(19)\end{array}$ & $\begin{array}{c}10.6 \% \\
(23) \\
\end{array}$ \\
\hline $\begin{array}{l}\text { Communication and } \\
\text { relationships }\end{array}$ & $\begin{array}{c}34.2 \% \\
(26)\end{array}$ & $\begin{array}{c}9.4 \% \\
(5)\end{array}$ & $\begin{array}{c}12.4 \% \\
(11)\end{array}$ & $\begin{array}{c}19.3 \% \\
(42) \\
\end{array}$ \\
\hline School related issues & $\begin{array}{c}2.6 \% \\
(2) \\
\end{array}$ & $\begin{array}{c}18.9 \% \\
(10)\end{array}$ & $\begin{array}{c}7.9 \% \\
(7)\end{array}$ & $\begin{array}{l}8.7 \% \\
(19) \\
\end{array}$ \\
\hline English learning & $\begin{array}{l}28.9 \% \\
(22)\end{array}$ & $\begin{array}{l}18.9 \% \\
(10)\end{array}$ & $\begin{array}{l}4.5 \% \\
(4)\end{array}$ & $\begin{array}{c}16.5 \% \\
(36)\end{array}$ \\
\hline
\end{tabular}

Toward the end of the program in the fall, the students' perception of LLSs became more indirect strategy oriented (i.e. Metacognitive, Affective, and Social Strategies) rather than direct strategy oriented (i.e. Memory, Cognitive, and Compensation Strategies). Change in 
the "English learning" category illustrates this. It is the only category whose percentage continuously dropped each term (28.9\% in the spring $\rightarrow 18.9 \%$ in the summer $\rightarrow 4.5 \%$ in the fall). In the fall, it ranked at the bottom of the six categories. The students' concept of language learning broadened over the three terms through learning experiences of different views of the world including their own country, culture, and themselves. The following comments of two students illustrate the development of their realization over the three terms:

\section{[Student \#1]}

Spring: I paid attention only to English learning at the beginning when I came to Portland, but recently I have realized that I need to look at some other things and learn whatever I can. My realization has allowed me to think about my strength, which makes me feel "Wow!" in many ways.

Summer: I can communicate with my host mother much better than before. This relates not only to the improvement of my English ability, but also to a better relationship with her by keeping suitable distance between us.

Fall: I have recognized that my efforts were not enough to improve my English and have been actually unsatisfied with my English improvement. However, I'm happy with my experiences in the United States; I have thought about many things, struggling with them and convincing myself. ... Now I 
look forward to what I will think about when I go back to Japan.

\section{[Student \#2]}

Spring: . I I was excited when the bus driver understood my question in English. Until then I didn't have enough confidence to ask people questions, but my experience with the driver improved my confidence.

Summer: Two months have already passed since the ESL program started. At the beginning, I felt very frustrated with myself because I knew I didn't participate in class. Now I feel better in class and enjoy my classes.

Fall: My experiences in Portland are very important and precious; I thought about many things very hard and recognized some changes within myself. My experiences here will be treasured in my life.

The students' comments in their dialogue journals from the spring through fall provide meaningful data. By recording their concerns, questions, and excitement in the dialogue journals and by sharing them with their classmates in the weekly tutoring sessions, the students maintained a psychological balance. They learned there were other classmates with the same concerns and problems. They empathized with their friends and classmates, crying and laughing together. These are strategies included in Affective and Social Strategies in the SILL, and this increase relates to the changes of 
the median scores in the SILLs. Table XVI summarizes median score comparisons of Affective and Social Strategies.

TABLE XVI

WILCOXON MATCHED-PAIRED SIGNED-RANKS TEST: MEDIAN SCORE COMPARISONS OF AFFECTIVE AND SOCIAL STRATEGIES

(SILLs \#1, \#2, \& \#3)

[LT GROUP, $\mathrm{N}=14$ ]

\begin{tabular}{lccc||ccc}
\cline { 2 - 7 } & \multicolumn{3}{c||}{ Median } & \multicolumn{3}{c}{ P value } \\
\cline { 2 - 7 } & $\begin{array}{c}\text { SILL \#1 } \\
\text { [L1] }\end{array}$ & $\begin{array}{c}\text { SILL \#2 } \\
\text { [L2] }\end{array}$ & $\begin{array}{c}\text { SILL \#3 } \\
\text { [L2] }\end{array}$ & \begin{tabular}{|l|lll} 
SILL \#1 \\
with \#2
\end{tabular} & $\begin{array}{c}\text { SILL \#2 } \\
\text { with \#3 }\end{array}$ & $\begin{array}{c}\text { SILL \#1 } \\
\text { with \#3 }\end{array}$ \\
\hline [E] Affective & 3.0 & 4.0 & 4.0 & $.0076^{*}$ & .1536 & $.0119^{*}$ \\
\hline [F] Social & 2.0 & 4.0 & 4.0 & $.0033^{*}$ & .4990 & $.0060^{*}$ \\
\hline
\end{tabular}

* Statistically significant at $\mathrm{P}=<.0167$

1: Never or almost never true of me

3: Somewhat true of me

2: Usually not true of me

5: Always or almost always true of me

4: Usually true of me

The following comments written by three different students explain their use of indirect strategies:

S: Last session our tutor told us that we, as 20-year old students, were trying to get something impossible--trying to use 20 years of English. I agree with this. My stress has gone. . . We sometimes need someone who can comprehend the Japanese language and who listens to us and understands what we really mean. (Spring)

S: Today I feel relieved to hear other students' problems and concerns. (Summer) 
S: I am very happy with this tutoring session where we can discuss our concerns and feelings with our tutor and classmates. I appreciate it. (Fall)

\section{Card Ranking Activity}

The results of the card ranking activity were divided into two groups: the ST Group ( $\mathrm{N}=28)$ and the LT Group ( $\mathrm{N}=15)$. Four months after the ST Group returned to the L1, 17 students took part in a card ranking activity. Fourteen students out of the LT Group who stayed in the L2 for three terms participated in the activity just before their departure from the L2.

In this section, the top five subcategories both in positive and negative emotions and experiences will be discussed with other related subcategories. In addition, subcategories in the "English learning" category will be explained.

\section{Card ranking system.}

In order to rank subcategories, the researcher took two steps: looking at the number of students, first, and then, median scores. Median scores, instead of mean scores, were used here due to the ordinal data of the card ranking activity. The Likert-scale ranges from 1 , the smallest, to 10 , the largest; the smallest figure indicates the most positive or negative learning experience of the students who chose a given subcategory. In other words, a subcategory with a bigger number of students and a smaller median score was placed higher in the overall ranking system (see Appendix $\mathrm{H}$ ). 
Tables XVII and XVIII show the top five, both positive and negative emotions and experiences, of subcategories that the students of the LT and ST Groups ranked. There are three characteristics found in these two tables. First, more than half of the subcategories are the same in both groups, which indicates the students' similar perception of their experiences regardless of their different lengths of time in the L2. Second, most of the subcategories are associated with communication and human relationships between the students and others. Third, indirect strategies in the SILL are acknowledged (i.e. Metacognitive, Affective and Social Strategies). In the following section, positive and negative emotions and experiences will be discussed individually.

\section{Positive Emotions and Experiences}

As shown in Tables XVII and XVIII, even though there are differences in ranks, the following four subcategories are found in both the LT and ST Groups: "encouragement and advice from teachers and others," "personal growth," "thinking about what I never thought about before," and "challenging various new things." More than $70 \%$ of the students of both groups evaluated these subcategories as positive experiences regardless of their different lengths of time in the L2.

There are also other subcategories chosen as positive experiences by more than half of the students in both groups: "everyday communication" (ST: $64.7 \%$, median $(\mathrm{m})=6.0$; LT: 50.0\%, 
TABLE XVII

THE LT GROUP STUDENTS [N=14]

\section{POSITIVE EMOTIONS AND EXPERIENCES}

\begin{tabular}{cccl}
\hline Rank & $\%$ & Median & \multicolumn{1}{c}{ Subcategory } \\
\hline 1 & $78.6 \%(11)$ & 3.0 & $\begin{array}{l}\text { Encouragement \& advice } \\
\text { from teachers \& others }\end{array}$ \\
\hline 2 & $"$ & 5.0 & Personal growth \\
\hline 3 & $71.4 \%(10)$ & 3.5 & $\begin{array}{l}\text { Thinking about what I never } \\
\text { thought about before }\end{array}$ \\
\hline 4 & $"$ & 4.0 & Relationships with friends \\
\hline 5 & $"$ & 5.0 & $\begin{array}{l}\text { Challenging various new } \\
\text { things }\end{array}$ \\
\hline
\end{tabular}

(Number of students)

\section{NEGATIVE EMOTIONS AND EXPERIENCES}

\begin{tabular}{cccl}
\hline Rank & $\%$ & Median & \multicolumn{1}{c}{ Subcategory } \\
\hline 1 & $71.4 \%(10)$ & 3.5 & $\begin{array}{l}\text { Gap between expect. \& } \\
\text { reality of Eng. improvement }\end{array}$ \\
\hline 2 & $64.3 \%(9)$ & 7.0 & Knowledge of Japan \\
\hline 3 & $57.1 \%(8)$ & 5.0 & Expressing feelings in Eng. \\
\hline 4 & $50.0 \%(7)$ & 3.0 & Returning to Japan \\
\hline 5 & 1 & 5.0 & $\begin{array}{l}\text { Future plans after } \\
\text { graduating from school }\end{array}$ \\
\cline { 2 - 4 } & " & Speaking skills \\
\hline
\end{tabular}

(Number of students)
TABLE XVIII THE ST GROUP STUDENTS [N=17]

\section{POSITIVE EMOTIONS AND EXPERIENCES}

\begin{tabular}{cccl}
\hline Rank & $\%$ & Median & \multicolumn{1}{c}{ Subcategory } \\
\hline 1 & $82.4 \%$ (14) & 2.0 & $\begin{array}{l}\text { Communication \& relation- } \\
\text { ships with host family }\end{array}$ \\
\hline 2 & $76.5 \%$ (13) & 3.0 & $\begin{array}{l}\text { Thinking about what I never } \\
\text { thought about before }\end{array}$ \\
\cline { 2 - 4 } & & " & Personal growth \\
\hline 4 & " & 4.0 & $\begin{array}{l}\text { Challenging various new } \\
\text { things }\end{array}$ \\
\hline 5 & $70.6 \%(12)$ & 4.5 & $\begin{array}{l}\text { Encouragement \& advice } \\
\text { from teachers and others }\end{array}$ \\
\hline
\end{tabular}

(Number of students)

\section{NEGATIVE EMOTIONS AND EXPERIENCES}

\begin{tabular}{cccc}
\hline Rank & $\%$ & Median & \multicolumn{1}{c}{ Subcategory } \\
\hline 1 & $82.4 \%(14)$ & 3.0 & Returning to Japan \\
\hline 2 & $58.8 \%(10)$ & 3.5 & Relationships w/ roommates \\
\hline 3 & 1 & 4.0 & Speaking skills \\
\hline 4 & $52.9 \%(9)$ & 4.0 & Vocabulary/idiom skills \\
\hline 5 & 1 & 5.0 & Expressing feelings in Eng. \\
\hline
\end{tabular}

(Number of students) 
$\mathrm{m}=7.0$ ), and "communication and relationships with host family" (ST: 82.4\%, $\mathrm{m}=2.0 ; \mathrm{LT}: 64.3 \%, \mathrm{~m}=3.0$ )" (see Appendix H).

In the L2, the students thought about what they had never thought about before in the L1 (LT Group: 71.4\%, $\mathrm{m}=3.5$; ST Group: $76.5 \%, \mathrm{~m}=4.0$ ) by encountering and challenging various new things (LT Group: 71.4\%, $\mathrm{m}=5.0$; ST Group: 76.5\%, $\mathrm{m}=4.0$ ). Their experiences gave them opportunities to pay attention to who they were and what they did. This assisted the process of their personal growth (LT Group: 78.6\%, $\mathrm{m}=5.0$; ST Group: $76.5 \%, \mathrm{~m}=3.0$ ), and the students evaluated it highly. According to the tables, encouragement and advice were essential to the success of language learning (LT Group: 78.6\%, $\mathrm{m}=3.0$; ST Group: 70.6\%, $\mathrm{m}=4.5$ ). Their teachers, host families, and other people around them supported the students in many ways.

As for additional characteristics, the "listening skills" subcategory is taken more positively by the ST Group $(58.8 \%, \mathrm{~m}=6.0)$ than by the LT Group (21.4\%, $\mathrm{m}=3.0$ ). This indicates the ST Group students, in the L1, valued the improvement of their listening skills by thinking retrospectively about their experiences in the L2 ; whereas, the LT Group students, still in the L2 when they participated in the card ranking activity, did not look back at their experiences as the ST Group did.

\section{Negative Emotions and Experiences}

The following three subcategories are included in negative 
emotions and experiences in both groups: "expressing feelings in English," "speaking skills," and "returning to Japan." The first two subcategories indicate the opposite perspective of the subcategories in the positive emotions and experiences related to communication and relationships.

Their limited English abilities, particularly speaking skills, frustrated the students (LT Group: 50.0\%, $\mathrm{m}=5.0$; ST Group: 58.8\%, $\mathrm{m}=4.0$ ). The students could not explicitly communicate their feelings and thoughts in English due to their insufficient vocabulary/idiom skills. In particular the ST Group students perceived their vocabulary skills more negatively than did the LT Group students (ST Group: 52.9\%, $\mathrm{m}=4.0$; LT Group: $21.4 \%, \mathrm{~m}=7.0$ ). This also illustrates why the percentage of student comments on "expectation and reality" increased over the terms, evidencing a larger gap between student expectations and reality. (see Tables XVII and XVIII).

The LT Group students stayed in the L2 four months longer than did the ST Group students. This may be why the category of "gap between expectation and reality of English improvement" was chosen by more students in the LT Group $(71.4 \%, \mathrm{~m}=3.5)$ than in the ST Group (41.2\%, $\mathrm{m}=3.0$ ). The LT Group students had more experiences that made them realize their unrealistic expectation, yet they eventually interpreted it in a positive way as a learning experience with a broader view of English learning.

The subcategory of "knowledge of Japan" was negatively 
interpreted by more students in the LT Group than by the ST students (LT Group: $64.3 \%, \mathrm{~m}=7.0$; ST Group: $23.5 \%, \mathrm{~m}=5.5$ ). These results directly connect to the length of time and number of experiences of the LT Group students in the L2. Although the students had more opportunities to explain about Japanese culture and traditions, they were not satisfied with their explanations. This dissatisfaction corresponds to the negative perception of their speaking skills.

Because of the different lengths of stay in the L2, the students' relationships with friends and roommates from Otemae resulted in significantly different experiences. The LT Group students spent a long enough time to maintain their relationships with their friends and roommates. The category of "relationships with friends," one of the top five subcategories of positive feelings and experiences illustrates this (LT Group: 71.4\%, 4.0; ST Group: 29.4\%, $\mathrm{m}=5.0$ ). The ST Group students remembered their relationships with roommates more negatively than did the LT Group students (ST Group: 58.8\%, $\mathrm{m}=3.5$; LT Group: $35.7 \%, \mathrm{~m}=6.0$ ).

The subcategory of "returning to Japan" indicates their desire to stay longer in the L2; the ST Group students demonstrated it more negatively than the LT Group students (ST Group: $82.4 \%$, $\mathrm{m}=3.0$; LT Group: $50.0 \%, \mathrm{~m}=3.0$ ). The subcategory of "future plans after graduating from school" corresponds to the "returning to Japan" subcategory of the LT Group students. They felt content with their longer stay in the L2, but at the same time they felt 
behind in the L1 because of their longer stay; other Otemae students in Japan had already started searching for jobs.

\section{Ranking of Subcategories of "English Learning"}

As explained previously, the students' comments on "English learning" were the major concern during the spring and the summer terms, but the number of comments on this decreased each term. The students cultivated their understanding of English learning in the L2 and eventually focused more on indirect strategies than on direct strategies. This was evidenced in the increase of the median scores of Affective and Social Strategies in the comparison between SILLs \#1 and \#3. (see Table XVI)

Due to the students' insufficient skills of the English language in the $\mathbf{L} 2$, the students interpreted "English learning" negatively in the card ranking activity. Table XIX summarizes positive and negative ranking of subcategories on "English Learning." According to the table, the ST Group students paid more attention to "English learning" than did the LT Group students. Although there are some differences in the ranks between the LT and ST groups, the four subcategories: "speaking," "pronunciation," "listening," and "vocabulary/idiom" are those with which the students were more concerned than other skills (i.e. grammar, writing, and reading). These four are closely associated with verbal communication, and they illustrate the students' weaknesses in communicating in English. This reflects the fact that English education in Japan 
focuses less on communicative skills.

TABLE XIX

SUBCATEGORY RANKING OF "ENGLISH LEARNING"

\begin{tabular}{|c|c|c|c|c|}
\hline \multirow{2}{*}{$\begin{array}{l}\text { LT GROUP }[\mathbf{N}=14] \\
\text { Skills }\end{array}$} & \multicolumn{2}{|c|}{ Positive } & \multicolumn{2}{|c|}{ Negative } \\
\hline & $\%$ & Median & $\%$ & Median \\
\hline Speaking & $7.1 \%(1)$ & 7.0 & $\mathbf{5 0 . 0 \%}(7)$ & 5.0 \\
\hline Pronunciation & $21.4 \%(3)$ & 10.0 & $21.4 \%(3)$ & 6.0 \\
\hline Listening & $7.1 \%(1)$ & 6.0 & $28.5 \%(4)$ & 3.0 \\
\hline Vocabulary/idiom & $--(0)$ & -- & $21.4 \%(3)$ & 3.0 \\
\hline How to study English & $7.1 \%(1)$ & 6.0 & $14.3 \%(2)$ & 7.5 \\
\hline Grammar & $--(0)$ & -- & $7.1 \%(1)$ & 3.0 \\
\hline Reading & $-(0)$ & - & $7.1 \%(1)$ & 5.0 \\
\hline Writing-- (0) & $--(0)$ & -- & $\ldots(0)$ & -- \\
\hline Total & $5.4 \%(6)$ & - & $18.8 \%(21)$ & -- \\
\hline
\end{tabular}

\begin{tabular}{|c|c|c|c|c|}
\hline \multirow{2}{*}{$\begin{array}{c}\text { ST GROUP }[\mathrm{N}=17] \\
\text { Skills } \\
\end{array}$} & \multicolumn{2}{|c|}{ Positive } & \multicolumn{2}{|c|}{ Negative } \\
\hline & $\%$ & Median & $\%$ & Median \\
\hline Listening & $\mathbf{5 8 . 8 \%}(10)$ & 6.0 & $17.6 \%(3)$ & 4.0 \\
\hline Speaking & $11.8 \%(2)$ & 2.0 & $\mathbf{5 8 . 8 \%}(10)$ & 4.0 \\
\hline Vocabulary/idiom & $-(0)$ & -- & $52.9 \%(9)$ & 4.0 \\
\hline Pronunciation & $5.9 \%(1)$ & 8.0 & $23.5 \%(4)$ & 5.5 \\
\hline Grammar & $-(0)$ & - & $23.5 \%(4)$ & 5.5 \\
\hline How to study English & $11.8 \%(2)$ & 7.0 & $5.9 \%(1)$ & 4.0 \\
\hline Writing & $11.8 \%(2)$ & 6.5 & $5.9 \%(1)$ & 10.0 \\
\hline Reading & $5.9 \%(1)$ & 10.0 & $11.8 \%(2)$ & 6.5 \\
\hline Total & $11.8 \%(18)$ & - & $25.0 \%(34)$ & -- \\
\hline
\end{tabular}

Due to the insufficient communicative skills of the students, they experienced frustration in communicating their thoughts and 
feelings with people in English, particularly with their host families. Their encounters with the English language in the L2 provided them with opportunities to review the process of their English learning as well as themselves as language learners. The students perceived English learning from cognitive, psychological, social, and cultural perspectives; their language learning experiences became the process of human development rather than a simply academic learning at school. The following comments were written by the same student at different tutoring sessions in the fall term. They illustrate her experiences in the L2:

S: I could not let myself leave Japan psychologically even though I have been in America for six months. Within my thoughts and everyday life, I recognize Japan, which has made me curious about myself who now views Japan objectively. This is the difference that I have realized within me recently.

S: America interests me in many ways: ethnic and cultural diversity ... Japanese people seem to try to assimilate themselves in different cultures. When I first came to America, I recalled I was trying to assimilate myself here. ... but now I behave as who I am as Japanese.

The final chapter will discuss implications of this study, limits of the study, suggestions for the Otemae program, and suggestions for further research. 


\section{CHAPTER VI}

\section{CONCLUSION}

This final section will discuss how the results of this study may make the Otemae program more beneficial for future students as well as implications for teaching, the limitation of the study and recommendations for further research.

Language learning is a complex mental and social process which involves multi-folded difficulties (i.e. linguistic grammatical competence, social acceptability, aptitude, and flexibility) (Kramsch, 1988). Otemae students in the 1995 program came to the United States to learn English, but this involves more than a physical transition from one environment to another, a concept which the students had not anticipated. Their greatest achievement in the L2 was the conceptual development of metalinguistic awareness of the language and culture.

Coming into the program with a concept of language learning based on a grammar translation model, the students had to adjust their LLSs to a more communicative-oriented methodology in the L2. There was a shift of view of English from being only on academic requirement to being a practical means of communication.

The students' LLSs increased in frequency and variety of use when the language environment changed from the L1 to the L2. 
However, this study did not clearly show which was more influential on their LLSs -- the different context or the length of time in the L2. The students perceived their LLSs in the L2 from a more practical communicative aspect rather than from a more traditional academic aspect. The LLSs of the students in the LT Group continued to improve during an additional term in the L2. In contrast, LLSs of the ST Group students regressed to their LLS level after only four months back in the L1 (except Affective and Social Strategies).

These results indicate the following:

- Direct strategies were adjusted according to English learning experience in a different language learning situation.

- Indirect strategies were retained regardless of the L1 or the L2.

As Oxford (1990a) emphasized, indirect strategies are as important as direct strategies even though direct strategies are more easily focused on by teachers and learners. Dialogue journals and the card ranking activity in this study exhibited the importance of indirect strategies in the language learning process.

Another important achievement was realization of interpersonal interaction in English in social and cultural contexts. Faced with different social and cultural contexts, the students began to comprehend the complexities of communication. They were frustrated with their insufficient vocabulary and speaking skills that often led to misunderstanding. A lack of these skills, however, may 
not have been the only factor. Misunderstanding could also occur due to the differences between Japanese and English. Nishiyama (1995) comments on: " . . the differences between Japanese and English in the usual sequence of presenting information, semantic differences between Japanese and English words and phrases, and differences in social assumptions and values" (p. 27).

The results indicate that over time students became more interested and motivated to learn about the target language as well as their native language. Teachers and/or tutor(s) in the Otemae program should emphasize the above differences during the first term at PSU. This type of instruction will help students to broaden their view of the language learning process.

The Otemae program is a short-term intensive course at PSU. The focus of the course is on communicative language learning through intercultural and interactional competence. However, the initial expectations of the Otemae students were different from the focus of the course. This was supported by the results of the card ranking activity which showed a gap between their expectations and reality of English improvement in the L2. It took one or two terms for the students to realize this gap. This should be presented to the participants during the pre-departure orientation, and reintroduced throughout the program in the L2. This expectational gap will be addressed later under "Suggestions for the Otemae program at PSU in the future." 
Limitations of the study, suggestions for the Otemae program at PSU, and suggestions for further research will be addressed in the following section.

\section{Limitations of the Study}

- Number of participants

Brown (1988) considers at least 60 as the minimum size of population for studies like the SILL; however, there were 43 students in the 1995 Otemae program. Forty of them participated in SILLs \#1 and \#2, and 15 out of 28 ST Group students and 14 out of 15 LT Group students took part in SILL \#3. The results of the SILL adequately represent the LLSs of the students in the 1995 Otemae program even though larger population of participants might have produced a more comprehensive explanation of the LLSs

- Questions in the SILL

The SILL (Version 7.0) was designed for ESL /EFL students from the perspective of ESL based strategies; therefore, not all of the questions are appropriate. The SILL suggests more Westernbased strategies rather than Eastern-based (Leong, 1993) and does not address the cultural preference for LLSs (Mills, 1995). Some strategies of the SILL are simply not applicable in the EFL situation (i.e. Japan, Korea, etc.). The SILL can be a good means to observe individual LLSs trends, yet researchers or teachers must monitor carefully regarding this cultural preference of the LLSs. 
- Classifications of comments from the dialogue journals In spite of an attempt to classify the comments from students' dialogue journals objectively, there is a possibility of a subjectively biased classification. The level of subjectivity would have been decreased by having participants classify their own comments.

\section{Recommendations for Future Otemae Programs at PSU}

- Administration of the SILL in the L1

In order to raise student level of awareness of LLSs, the initial SILL can be administered in the L1 before departure. The second one can be administered to students after the summer term in the L2. Observable difference from a comparison of the SILLs will enhance the concept of the language learning process for the participants.

- Pre-departure orientation at Otemae College

The pre-departure orientation is an important stage for those who will participate in the Otemae program at PSU. It can improve the program overall specifically by providing the students with cultural insights combined with input from experiences of previous students (i.e. useful LLSs in the L2, a gap between expectations and reality of English improvement, concepts of English learning and communication).

- Japanese mentor(s) or tutor(s)

A Japanese graduate student (the researcher) coordinated 
weekly tutoring sessions for the students in the 1995 Otemae program. The students visited these sessions on a voluntary basis, discussed, and shared their experiences in the L2. The tutor satisfied one of the requirements for the TESOL Methods class in the spring term by tutoring Otemae students. She also attended the teachers' weekly meetings during the spring term, consulting on behaviors of Japanese students. She played the role of a moderator/facilitator for the students and acted as a liaison between the teachers and the students. The tutoring sessions lowered the students' anxiety and stress levels. The tutor provided an avenue of communication for the students in Japanese. The students indicated appreciation for "encouragement and advice from teachers and others (C29)" (see Appendix $\mathrm{H}$ ) and evaluated this subcategory positively as shown in the results of the card ranking activity.

- The Otemae program with the TESOL Methods classes The researcher proposes a reciprocal relationship of mutual benefit between the Otemae program and the TESOL Methods classes. Japanese students in the TESOL program can provide potential candidates for mentors for Otemae students. The TESOL students can fulfill their class requirements and practice teaching and tutoring; at the same time Otemae students can receive individualized attention academically and personally. The TESOL students would support Otemae students as their "big brothers or sisters." 


\section{Suggestions for Further Research}

Due to time limitations, further investigation of LLSs was not possible for the 1995 Otemae program. The study was based on the data from the SILL, dialogue journals, and the card ranking activity, yet the following suggestions would be helpful for future research:

- Administration of SILL \#4 to the LT Group students The fourth administration of the SILL to the LT Group students after they return to the $\mathrm{L} 1$ would produce additional data helpful for future investigation of influence on LLSs.

- Administration of SILL at Otemae College

The SILL can be administered to all of the Otemae students who major in American/English Literature in order to have more general ideas of the students' perceptions and attitudes of language learning and LLSs. Additionally, LLSs between students who participated in the program at PSU and those who did not can be compared. This comparison may exhibit more clearly how students' experiences in the L2 would affect their views of English learning and LLSs.

- Card sorting activity (by using the 40 cards used in the card ranking activity) to explain and understand the interrelationships among subcategories (favoritism, problems, questions, and concerns)

This allows teachers and coordinators of Otemae College and of PSU and American Heritage Association to predict potential 
factors that may hinder student progress of the learning process in the L2. Consideration of these factors will benefit future programs and participants.

- Correlation of LLSs by using the SILL at different times during the duration of the program

LLSs are interrelated with one another. If particular strategies that influence other strategies are found, teachers can focus more on those particular strategies. Further instruction in use of particular strategies may accelerate the process of SLA.

- Investigation of validity of the 50 questions in the SILL As explained in the limitations of the study, the LLSs in the SILL could be culturally biased. Therefore, modification of the SILL would be preferable, depending on where the SILL is administered.

- Comparisons of students' performance between the SILL and proficiency tests

Comparisons of students' performance on beginning and ending English proficiency tests and three administrations of the SILL would provide information about relationships between LLSs of successful and less successful learners and the test results.

There was a significant perceptual shift in language learning by the Otemae students from a simplistic grammatical focus to a more complex communicative one. Student concept of language learning was amplified through personal experiences in the L2. The students 
realized just how complex communication is, involving spoken language, non-verbal communication, body language, turn-taking, turn yielding, and intonation that are culturally determined (Kramsch, 1987).

By observing the perceptual changes in the Otemae students, the researcher expanded her understanding of communication as " . . a socialization process that involves the whole personal and social development of the learner ... " (Kramsch, 1983, p. 177). It was predicted that the LLSs of the students would change according to different language learning environments. Therefore, the attitudinal changes in the Otemae students were unexpected.

The students' experience let them perceive not only their country, but also themselves objectively. This is what the Otemae students could not experience in Japan. The language learning experience involved self improvement and raised self and cultural awareness.

As a Japanese user of English, the researcher also recognized the importance of her role as a model for the Otemae students. The English language functioned as a tool for communication in the L2. They raised their confidence level through negotiating and interacting with many individuals in Portland who were not "native speakers" of English.

The following translated student comments serve as an appropriate conclusion:

S: I have learned a new way of thinking. Being egocentric, 
I paid attention only to myself, so when I felt depressed, I psychologically isolated myself from others by persuading myself that I was different from them. I didn't try to put myself in others' shoes; I didn't consider their ways of thinking and behaving.

S: I didn't have much confidence in my English because of my previous learning experience in Japan. However, I feel like being able to have more confidence now.

S: I have recognized some changes in myself and my motivation toward English learning. ... I can feel that my motivation has become much stronger. It was not so strong when I was in Japan. 


\section{REFERENCES}

Benedict, R. (1947). The chrysanthemum and the sword. London: Secker and Warburg.

Berns, M. (1990). 'Second' and 'foreign' in second language acquisition/foreign language learning: A sociolinguistic perspective. In B. VanPatten, \& J. F. Lee, (Eds.), Second language acquisition/foreign language learning, 3-11. Clevedon: Multilingual Matters, Ltd.

Bialystok, E. (1978). A theoretical model of second language learning. Language Learning, $\underline{28}, 69-83$.

Brown, H. D. (1987). Principles of language learning and teaching. (2nd ed.). Englewood Cliffs, NJ: Prentice Hall Regents.

Brown, H. D. (1994). Teaching by principles: An interactive approach to language pedagogy. Englewood Cliffs, NJ: Prentice Hall Regents.

Brown, J. D. (1988). Understanding research in second language learning: A teacher's guide to statistics and research design. New York: Cambridge University Press.

Brumfit, C. J. (1980). From defining to designing: Communicative specifications vs. communicative methodology in foreign language teaching. In K. Müller (Ed.), Studies in second language acquisition, $\underline{3}$ (1). Bloomington, IN: Indiana University Publications.

Chamot, A. U., \& Küpper, L. (1989). Learning strategies in foreign language instruction. Foreign Language Annals, 22 (1), 13-24.

Chamot, A. U., O'Malley, Küpper, \& Impink-Hernandez. (1987). A study of learning strategies in foreign language instruction: first year report. Rosslyn, VA: InterAmerica Research Associates. 
Cohen, A. D. (1995), March. Verbal reports as a source of insights on learner strategies. Paper presented at the colloquium on issues in the assessment of L2 learner strategies, AAAL annual conference, Long Beach, CA.

Crookes, G., \& Schmidt, R. (1989). Motivation: Reopening the research agenda. University of Haw aii Working Papers in ESL, $\underline{8}$, 217-256.

De Vos, G. A. (1985). Dimensions of the self in Japanese culture. In A. Marsella, G. De Vos, \& F. Hsu (Eds.), Cultural conceptions of mental health and therapy, 141-184. Dordrecht: Reidel.

Doi, T. (1974). Amae: A key concept for understanding Japanese personality structure. In T. S. Lebra \& W. P. Lebra (Eds.), Japanese culture and behavior, 145-154. Honolulu: The University Press of Hawaii. Kodansha.

Doi, T. (1981). The anatomy of dependence. Tokyo:

Ellis, R. (1985). Understanding second language acquisition. Oxford: Oxford University Press.

Ely, C. M. (1989). Tolerance of ambiguity and use of second language strategies. Foreign Language Annals, $\underline{22}$ (5), 437-445.

Gardner, R. C., \& MacIntyre, P. D. (1991). An instrumental motivation in language study: Who says it isn't effective? Studies in Second Language Acquisition, $13,57-72$.

Gardner, R. C., \& MacIntyre, P. D. (1992). A student's contributions to second-language learning. Part II: Affective variables. Language Teaching, $\underline{26}, 1-11$.

Haviland, W. A. (1990). Cultural anthropology. (6th ed.). Fort Worth, TX: Holt, Rinehart and Winston, Inc.

Honna, N., \& Hoffer, B. (1989). An English dictionary of Japanese ways of thinking. Tokyo: Yuhikaku. 
Ike, M. (1995). A historical review of English in Japan. World Englishes, 14 (1), 3-11.

Koike, I., \& Tanaka, H. (1995). English in foreign language education policy in Japan: Toward the twenty-first century. World Englishes, 14 (1), 13-25.

Kramsch, C. L. (1983). Culture and constructs: Communicating attitudes and values in the foreign language classroom. Foreign Language Annals, $\underline{16}$ (6), 437-448.

Kramsch, C. L. (1983). Interaction in the classroom: Learning to negotiate roles and meanings. Die Unterrichts - Praxis: For the . teaching of German, 16 (2), 175-190.

Kramsch, C. L. (1985). Classroom interaction and discourse options. Studies in Second Language Acquisition, 7 (2), 169-183.

Kramsch, C. L. (1986). From language proficiency to interactional competence. The Modern Language Journal, 70 (4), 366-372.

Kramsch, C. L. (1987). Socialization and literacy in a foreign language: Learning through interaction. Theory into Practice, $\underline{24}(4), 243-250$.

Kramsch, C. L. (1988). What is FLL (foreign language learning) research? Issues and Development in English and Applied Linguistics, $\underline{3}, 75-81$.

Kramsch, C. L. (1993). Context and culture in language teaching. Oxford: Oxford University Press.

Krashen, S., Long, M., \& Scarcella, R. (1979). Age, rate, and eventual attainment in second language acquisition. TESOL Quarterly, 13 (13), 573-582.

Lebra, T. S., \& Lebra, W. P. (1986). Japanese culture and behavior. Revised ed. Honolulu: University of Hawaii Press.

Leong, P. C. (1993). The study of Malaysian learners' strategies while studying a second language. Unpublished masters thesis, Portland State University. 
LoCastro, V. (1994). Learning strategies and learning environments. TESOL Quarterly, $\underline{28}$ (2), 409-414.

Magnan, S. S. (1990). Shifting the instructional focus to the learner. Middlebury, VT: Northeast Conference on the Teaching Foreign Languages.

Mills, C. F. (1995). Use of language learning strategies by proficient and less proficient learners. Unpublished masters thesis, Portland State University.

Nakane, C. (1970). Japanese society. Berkeley: University of California Press.

Nishiyama, S. (1995). Speaking English with a Japanese mind. World Englishes, 14 (1), 27-36.

Norusís, M. J. (1992). SPSS/PC+: Base system user's guide, version 5.0. Chicago, IL: SPSS, Inc.

Nunan, D. (1992). Research methods in language learning. Cambridge: Cambridge University Press.

Nyikos, M., \& Oxford, R. (1993). A factor analytic study of language-learning strategy use: Interpretation from information processing theory and social psychology. The Modern Language Journal, $\underline{74}, 273-287$.

O'Malley, J. M., Chamot, A. U., Stewner-Manzanares, G., Russo, R. P., \& Küpper, L. (1985). Learning strategy application with students of English as a second language. TESOL Quarterly, $\underline{19}$ (3), 557-584.

Ono, S. (1976). Fragile blossom, fragile superpower: A new interpretation? Japanese Quarterly, 23, 12-27.

Oxford, R. L. (1990a). Language learning strategies: What every teacher should know. Boston, MA: Heinle \& Heinle Publishers.

Oxford, R. L. (1990b). Missing link: Evidence from research on language learning styles and strategies. Georgetown University Round Table on Language and Linguistics. 438-458. 
Oxford, R. L., \& Crookall, D. (1989). Research on language learning strategies: Methods, findings, and instructional issues. The Modern Language Journal, $\underline{73}$, 404-419.

Oxford, R. L., \& Ehrman, M. (1993). Second language research on individual differences. Annual Review of Applied Linguistic, 13, 188-205.

Oxford, R. L., Lavine, R. Z., \& Crookall, D. (1989). Language learning strategies, the communicative approach, and their classroom implications. Foreign Language Annals, 22 (1), 29-39.

Parry, T. S., \& Stansfield, C. (1990). Language aptitude reconsidered. Englewood, NJ: Prentice Hall.

Pressley, M., \& Levin, J. R. (1983). Cognitive strategy research: Educational applications. New York: Springer-Verlag.

Reischauer, E. O. (1988). The Japanese today: Change and continuity. Cambridge, MA: Harvard University Press.

Reiss, M. (1981). Helping the unsuccessful language learner. The Modern Language Journal, $\underline{65}, 121-128$.

Rohlen, T. P. (1974). For harmony and strength: Japanese white-collar organization in anthropological perspective. Berkeley: University of California Press.

Rubin, J. (1975). What the "good language learner" can teach us. TESOL Quarterly, 9 (1), 41-51.

Rubin J. (1987). Learner strategies: Theoretical assumption, research history and typology. In A. Wenden \& J. Rubin (Eds.), Learner strategies in language learning, 15-30. Englewood Cliffs, NJ: Prentice/Hall International (UK) Ltd.

Scarcella, R. C., \& Oxford, R. L. (1992). The tapestry of language learning: The individual in the communicative classroom. Boston, MA: Heinle and Heinle.

Shimazu, M. (1984). Japanese students in EFL/ESL classrooms. TESOL Newsletter, $\underline{18}(2), 19$. 
Skehan, P. (1991). Individual differences in second language acquisition. Studies in Second Language Acquisition, 13 (2), 275-298.

Smith, R. J. (1983). Japanese society: Tradition, self, and the social order. Cambridge: Cambridge University Press.

Swain, M. (1979). Future directions in second language research. Manuscript discussed at TESOL Institute, Los Angeles.

Tarone, E. (1981). Some thoughts on the notion of communication strategy. TESOL Quarterly, 15 (3), 285-294.

Tollefson, J. W. (1981). The role of language planning in second language acquisition. Language Learning, $\underline{31}$ (2), 337-348.

Umehara, T. (1987). The constitution of seventeen articles and the spirit of wa. The Japanese mind: Essays on Japan from Japan. Tokyo: Maruzen Co. Ltd. 17-23.

Vann, R. J., \& Abraham, R. G. (1990). Strategies of unsuccessful language learners. TESOL Quarterly, $\underline{24}$ (2), 177-198.

Wenden, A. L. (1985). Learner strategies. TESOL Newsletter, $\underline{14}(5), 1-7$.

Wenden, A. L. (1987). Conceptual background and utility. In A. Wenden \& J. Rubin (Eds.), Learner strategies in language learning, 3-13. Englewood Cliffs, NJ: Prentice/Hall International (UK) Ltd.

Wenden, A. L. (1991). Learner Strategies for learner autonomy: Planning and implementing learner training for language learners. Englewood, NJ: Prentice-Hall. 


\section{APPENDIX A \\ OXFORD'S STRATEGY SYSTEM AND \\ DEFINITIONS OF LEARNING STRATEGIES \\ USED IN THE SILL}


Oxford's Strategy System

Direct Strategies: Memory, Cognitive, and Compensation Strategies (Oxford, 1990a, pp. 18-19)

\author{
MEMORY STRATEGIES \\ \begin{tabular}{|l} 
Creating mental linkages - \\
1. Grouping \\
2. Associating/elaborating \\
3 . Placing new words into a context
\end{tabular} \\ -Applying images and sounds $\rightarrow 1$. Using imagery \\ 2. Semantic mapping \\ 3. Using keywords \\ 4. Representing sounds in memory \\ Reviewing well 1 . Structured reviewing \\ Employing action $ـ 1$. Using physical response/sensation \\ 2. Using mechanical techniques
}

\title{
COGNITIVE STRATEGIES
}

\begin{tabular}{|c|c|}
\hline Practicing & $\begin{array}{l}\text { 1. Repeating systems } \\
\text { 2. Formally practicing with sounds \& writing } \\
\text { 3. Recognizing and using formulas \& patterns } \\
\text { 4. Recombining } \\
\text { 5. Practicing naturalistically }\end{array}$ \\
\hline $\begin{array}{l}\text { Receiving and sending - } \\
\text { messages }\end{array}$ & $\begin{array}{l}\text { 1. Getting the idea quickly } \\
\text { 2. Using resources for receiving and sending } \\
\text { messages }\end{array}$ \\
\hline Analyzing and reasoning & $\begin{array}{l}\text { 1. Reasoning deductively } \\
\text { 2. Analyzing expressions } \\
\text { 3. Analyzing contrastively (across languages) } \\
\text { 4. Translating } \\
\text { 5. Transferring }\end{array}$ \\
\hline $\begin{array}{l}\text { Creating structure for- } \\
\text { input and output }\end{array}$ & $\begin{array}{l}\text { 1. Taking notes } \\
\text { 2. Summarizing } \\
\text { 3. Highlighting }\end{array}$ \\
\hline
\end{tabular}

\section{COMPENSATIONSTRATEGIES}

Guessing intelligently $\longrightarrow 1$. Using linguistic clues

2. Using other clues

Overcoming limitations

1. Switching to the mother tongue

in speaking and writing

2. Getting help

3 . Using mime or gesture

4. Avoiding communication partially/totally

5. Selecting the topic

6. Adjusting or approximating the message

7. Coining words

8. Using a circumlocution or synonym 
Indirect Strategies: Metacognitive, Affective, and Social Strategies

(Oxford, 1990a, pp. 20-21)

\section{METACOGNITIVE STRATEGIES}

Centering your learning $\longrightarrow 1$. Overviewing and linking with already known

-2. Paying attention

3. Delaying speech production to focus on listening

Arranging and planning $\longrightarrow 1$. Finding out about language learning

your learning

2. Organizing

3. Setting goals and objectives

4. Identifying the purpose of a language task

(purposeful listening/reading/speaking/writing)

5. Planning for a language task

6. Seeking practice opportunities

Evaluating your learning__ 1 . Self-monitoring

2. Self-evaluating

\section{AFFECTIVE STRATEGIES}

Lowering your anxiety $\longrightarrow 1$. Using progressive relaxation, deep breathing, or meditation

2. Using music

3. Using laughter

Encouraging yourself

1. Making positive statements

2. Taking risks wisely

3. Rewarding yourself

Taking your emotional

1. Listening to your body temperature

2. Using a checklist

3. Writing a language learning diary

4. Discussing your feelings with someone else

\section{SOCIAL STRATEGIES}

Asking questions $\longrightarrow 1$ Asking for clarification or verification

2. Asking for correction

-Cooperating with others $\longrightarrow 1$. Cooperating with peers

2. Cooperating with proficient users of the new language

Empathizing with others $\longrightarrow 1$. Developing cultural understanding

2. Becoming aware of other's thought and feelings 


\section{DEFINITIONS OF STRATEGIES IN THE}

\section{STRATEGY INVENTORY FOR LANGUAGE LEARNING (SILL)}

(Source: Oxford, 1990a)

The following definition of the six strategy categories used in the study and the strategies that make up each category are taken verbatim from Oxford's book: Language Learning Strategies: What Every Teacher Should Know.

\section{Memory Strategies}

Memory strategies reflect very simple principles, such as arranging things in order, making associations, and reviewing. These principles all involve 'meaning'. For the purpose of learning a new language, the arrangement and associations must be personally meaningful to the learner, and the material to be reviewed must have significance.

\section{Creating Mental Linkages}

In this set are three strategies that form the cornerstone for the rest of memory strategies: grouping, associating/elaborating, and using context.

\section{Grouping.}

Classifying or reclassifying language material into meaningful units, either mentally or in writing, to make the material easier to remember by reducing the number of discrete elements. Groups can be based on type or word (e.g., all nouns or verbs), topic (e.g., words about weather), practical function (e.g., terms for things that make a car work), linguistic function (e.g., apology, request, demand), similarity (e.g., warm, hot, tepid, tropical), dissimilarity or opposition (e.g., friendly/unfriendly), the way one feels about something (e.g., like, dislike), and so on. The power of this strategy may be enhanced by labeling the groups, using acronyms to remember the groups, or using different colors to represent deferent groups. 


\section{Associating/Elaborating.}

Relating new language information to concepts already in memory, or relating one piece of information to another, to create associations in memory. These associations can be simple or complex, mundane or strange, but they must be meaningful to the learner. Associations can be between two things, such as bread and butter, or they can be in the form of a multipart "development," such as school-book-paper-tree-country-earth. They can also be part of a network, such as a semantic map (see below)

\section{Applying Images and Sounds}

Four strategies are included here: using imagery, using keywords, semantic mapping, and representing sounds in memory. These all involve remembering by means of visual images or sounds.

\section{Using imagery.}

Relating new language information to concepts in memory by means of meaningful visual imagery, either in the mind or in an actual drawing. The image can be a picture of an object, a set of locations for remembering a sequenced of words or expressions, or a mental representation of the letters of a word. This strategy can be used to remember abstract words by associating such words with a visual symbol or a picture of a concrete object.

\section{Semantic mapping.}

Making an arrangement of words into a picture, which has a key concept at the center or at the top, and related words and concepts linked with the key concept by means of lines or arrows. This strategy involves meaningful imagery, grouping, and associations; it visually shows how certain groups of words relate to each other.

\section{Using keywords.}

Remembering a new word by using auditory and visual links. The first step is to identify a familiar word in one's own language that sounds like the new word--this is the "auditory link." The second step is to generate an 
image of some relationship between the new word and a familiar one--this is the "visual link." Both links must be meaningful to the learner. For example, to learn the new French word potage (soup), the English speaker associates it with a pot and then pictures a pot full of potage. To use a keyword to remember something abstract, such as a name, associate it with a picture of something concrete that sounds like the new word. For example, Minnesota can be remembered by the image of a mini soda.

\section{Representing sounds in memory.}

Remembering new language information according to its sound. This is a broad strategy that can se any number of techniques, all of which create a meaningful sound-based association between the new material and already known material. for instance, you can (a) link a target language word with any other word (in any language) that sounds like the target language word, such as Russian brat (brother) and English brat (annoying person), (b) use phonetic spelling and/or accent marks, or (c) use rhymes to remember a word.

\section{Reviewing Well}

This category contains just one strategy, structured reviewing. Looking at new target language information once is not enough; it must be reviewed in order to be remembered.

\section{Structured reviewing.}

Reviewing in carefully spaced intervals, at first close together and then more widely spaced apart. This strategy might start, for example, with a review 10 minutes after the initial learning, then 20 minutes later, an hour or two later, a day later, 2 days later, a week later, and so on. This is sometimes called "spiraling," because the learner keeps spiraling back to what has already been learned at the same time that he or she is learning new information. The goal is "overlearning"--that is, being so familiar with the information that it becomes natural and automatic. 
Employing Action

The two strategies in this set, using physical response or sensation and using mechanical tricks, both involve some kind of meaningful movement or action. These strategies will appeal to learners who enjoy the kinesthetic or tactile modes of learning.

\section{Using physical response or sensation.}

Physically acting out a new expression (e.g., going to the door), or meaningfully relating a new expression to a physical feeling or sensation (e.g., warmth).

\section{Using mechanical techniques.}

Using creative but tangible techniques, especially involving moving or changing something which is concrete, in order to remember new target language information. Examples are writing words on cards and moving cards from one stack to another when a word is learned, and putting different types of material in separate sections of a language learning notebook.

\section{Cognitive Strategies}

Cognitive strategies are essential in learning a new language. Such strategies are a varied lot, ranging from repeating to analyzing expressions to summarizing. With all their variety, cognitive strategies are unified by a common function: manipulation or transformation of the target language by the learner. Cognitive strategies are typically found to be the most popular strategies with language learners.

\section{Practicing}

Of the five practicing strategies, probably the most significant one is practicing naturalistically.

\section{Repeating.}

saying or doing something over and over: listening to something several times; rehearsing; imitating a native speaker. 
2. Formally practicing with sounds and writing systems.

Practicing sounds (pronunciation, intonation, register, etc.) in a variety of ways, but not yet in naturalistic communicative practice; or practicing the new writing system of the target language.

3. Recognizing and using formulas and patterns.

Being aware of and/or using routine formulas (single, unanalyzed units), such as "hello, how are you?"; and unanalyzed patterns (which have at least one slot to be filled), such as, "It's time to

\section{Recombining.}

Combining known elements in new ways to produce a longer sequence, as in linking one phrase with another in a whole sentence.

\section{Practicing naturalistically.}

Practicing the new language in natural, realistic settings, as in participating in a conversation, reading a book or article, listening to a lecture, or writing a letter in the new language.

\section{Receiving and Sending Messages}

Two strategies for receiving and sending messages are (a) getting the idea quickly and (b) using resources for receiving and sending messages. The former uses two specific techniques for extracting ideas, while the latter involves using a variety of resources for understanding or producing meaning.

\section{Getting the idea quickly.}

Using skimming to determine the main ideas or scanning to find specific details of interest. This strategy helps learners understand rapidly what they hear or read in the new language. Preview questions often assist.

2. Using resources for receiving and sending messages.

Using print or nonprint resources to understand incoming messages or produce outgoing messages. 


\section{Analyzing and Reasoning}

This set of five strategies concerns logical analysis and reasoning as applied to various target language skills. Often learners can use these strategies to understand the meaning of a new expression or to create a new expression.

1. Reasoning deductively.

Using general rules and applying them to new target language situations. This is a top-down strategy leading from general to specific.

2. Analyzing expressions.

Determining the meaning of a new expression by breaking it down into parts; using the meanings of various parts to understand the meaning of the whole expression.

\section{Analyzing contrastively.}

Comparing elements (sounds, vocabulary, grammar) of the new language with elements of one's own language to determine similarities and differences.

\section{Translating.}

Converting a target language expression into the native language (at various levels, from words and phrases all the way up to whole texts); or converting the native language into the target language; using one language as the basis for understanding or producing another.

\section{Transferring.}

Directly applying knowledge of words, concepts, or structures from one language to another in order to understand or produce an expression in the new language.

\section{Creating Structure for Input and Output}

The following three strategies are ways to create structure, which is necessary for both comprehension and production an expression in the new language. 


\section{Taking notes.}

Writing down the main idea or specific points. This strategy can involve raw notes, or it can comprise a more systematic form of note-taking such as the shopping-list format, the T-formation, the semantic map, or the standard outline form.

\section{Summarizing.}

Making a summary or abstract of a longer passage.

\section{Highlighting.}

Using a variety of emphasis techniques (such as underlining, starring, or color-coding) to focus on important information in a passage.

\section{Compensation Strategies}

Compensation strategies enable learners to use the new language for either comprehension or production despite limitations in knowledge. Compensation strategies are intended to make up for an inadequate repertoire of grammar and, especially, of vocabulary. Ten compensation strategies exist, clustered into two sets: Guessing Intelligently in Listening and Reading, and Overcoming Limitations in Speaking and Writing. These two sets can be remembered by the acronym GO, since "Language learners can GO far with compensation strategies.”

\section{Guessing Intelligently in Listening and Reading}

The two strategies which contribute to guessing intelligently refer to two different kinds of clues: linguistic and nonlinguistic.

\section{Using linguistic clues.}

Seeking and using language-based clues in order to guess the meaning of what is heard or read in the target language, in the absence of complete knowledge of vocabulary, grammar, or other target language elements. Language-based clues may come from aspects of the target language that the learner already knows, from the learners' own language, or from another language. For instance, if the learner does not know the 
expression association sans but lucratif ("nonprofit association," in French), and French (sans = without) would give clues to the meaning of the unknown words, but (aim, goal), and of the whole expression.

\section{Using other clues.}

Seeking and using clues that are not language-based in order to guess the meaning of what is heard or read in the target language, in the absence of complete knowledge of vocabulary, grammar, or the target language elements. Nonlanguage clues may come from a wide variety of sources; knowledge of context, situation, text structure, personal relationships, topics, or "general world knowledge." For example, if the learner does not know what is meant by the words vends or à vendre in the French newspaper, noticing that these words are used in the context of classified ads, and that they are followed by a list of items and prices, provides clues suggesting that these terms probably refer to selling.

\section{Overcoming Limitations in Speaking and Writing}

Eight strategies are used for overcoming limitations in speaking and writing. Some of these are dedicated solely to speaking, but some can be used for writing, as well.

\section{Switching to the mother tongue.}

Using the mother tongue for an expression without translating it, as in Ich bin eine girl. This strategy may also include adding word endings from the new language onto words from the mother tongue.

\section{Getting help.}

Asking someone for help by hesitating or explicitly asking for the person to provide the missing expression in the target language.

\section{Using mime or gesture.}

Using physical motion, such as mime or gesture, in place of an expression to indicate the meaning. 


\section{Avoiding communication partially or totally.}

Partially or totally avoiding communication when difficulties are anticipated. This strategy may involve avoiding communication in general, avoiding certain topics, avoiding specific expressions, or abandoning communication in mid-utterance.

5. Selecting the topic.

Choosing the topic of conversation in order to direct the communication to one's own interests and make sure the topic is one in which the learner has sufficient vocabulary and grammar to converse.

\section{Adjusting or approximating the message.}

Altering the message by omitting some items of information, making ideas simpler or less precise, or saying something slightly different that means almost the same thing, such as saying pencil for pen.

\section{Coining words.}

Making up new words to communicate the desired idea, such as paperholder for notebook.

\section{Using a circumlocution or synonym.}

Getting the meaning across by describing the concept (circumlocution) or using a word that means the same thing (synonym); for example, "What you use to wash dishes with" as a description for dishrag.

\section{Metacognitive Strategies}

"Metacognitive" means beyond, beside, or with the cognitive. Therefore, metacognitive strategies are actions which go beyond purely cognitive devices, and which provide a way for learners to coordinate their own learning process.

\section{Centering Your Learning}

This set of three strategies helps learners to converge their attention 
and energies on certain language tasks, activities, skills or materials. Use of these strategies provides a focus for language learning.

\section{Overviewing and linking with already known material.}

Overviewing comprehensively a key concept, principle, or set of materials in an upcoming language activity and associating it with what is already known. This strategy can be accomplished in many different ways, but it is often helpful to follow three steps: learning why the activity is being done, building the needed vocabulary, and making the associations.

\section{Paying attention.}

Deciding in advance to pay attention in general to a language learning task and to ignore distracters (by directed attention), and/or to pay attention to specific aspects of the language or to situational details (by selective attention).

\section{Delaying speech production to focus on listening.}

Deciding in advance to delay speech production in the new language either totally or partially, until listening comprehension skills are better developed. Some language theorists encourage a "silent period" of delayed speech as part of the curriculum, but there is debate as to whether all students require this.

\section{Arranging and Planning Your Learning}

This set contains six strategies, all of which help learners to organize and plan so as to get the most out of language learning. These strategies touch many areas: finding out about language learning, organizing the schedule and the environment, setting goals and objectives, considering task purposes, planning for tasks, and seeking chances to practice the language.

\section{Finding out about language learning.}

Making efforts to find out how language learning works by reading books and talking with other people, and then suing this information to help improve one's own language learning. 
2. Organizing.

Understanding and using conditions related to optimal learning of the new language; organizing one's schedule, physical environment (e.g., space, temperature, sound, lighting), and language learning notebook.

\section{Setting goals and objectives.}

Setting aims for language learning, including long-term goals (such as being able to use the language for informal conversation by the end of the year) or short-term objectives (such as finishing reading a short story by Friday).

\section{Identifying the purpose of a language task.}

Deciding the purpose of a particular language task involving listening, reading, speaking, or writing. For example, listening to the radio to get the latest news on the stock exchange, reading a play for enjoyment, speaking to the cashier to buy a train ticket, writing a letter to persuade a friend not to do something rash. (This is sometimes known as Purposeful Listening/Speaking/Reading/Writing.)

\section{Planning for a language task.}

Planning for the language elements and functions necessary for an anticipated language task or situation. This strategy includes four steps: describing the task or situation, determining its requirements, checking one's own linguistic resources, and determining additional language elements or functions necessary for the task or situation.

6. Seeking practice opportunities.

Seeking out or creating opportunities to practice the new language in naturalistic situations, such as going to a second/foreign language cinema, attending a party where the language will be spoken, or joining an international social club. Consciously thinking in the new language also provides practice opportunities.

\section{Evaluating Your Learning}

In this set are two related strategies, both aiding learners in checking 
their language performance. One strategy involves noticing and learning from errors, and the other concerns evaluating overall progress.

\section{Self-monitoring.}

Identifying errors in understanding or producing the new language, determining which ones are important (those that cause serious confusion or offense), tracking the source of important errors, and trying to eliminate such errors.

\section{Self-evaluating.}

Evaluating one's own progress in the new language, for instance, by checking to see whether one is reading faster and understanding more than 1 month or 6 months ago, or whether one is understanding a greater percentage of each conversation.

\section{Affective Strategies}

The term affective refers to emotions, attitudes, motivations, and values. Language learners can gain control over these factors through affective strategies.

\section{Lowering Your Anxiety}

Three anxiety-reducing strategies are listed here. Each has a physical component and a mental component.

\section{Using progressive relaxation, deep breathing, or meditation.}

Using the technique of alternately tensing and relaxing all of the major muscle groups in the body, as well as the muscles in the neck and face, in order to relax; or the technique of breathing deeply from the diaphragm; or the technique of meditating by focusing on a mental image or sound.

\section{Using music.}

Listening to soothing music, such as a classical concert, as a way to relax. 


\section{Using laughter.}

Using laughter to relax by watching a funny movie, reading a humorous book, listening to jokes, and so on.

\section{Encouraging Yourself}

This set of three strategies if often forgotten by language learners, especially those who expect encouragement mainly from other people and do not realize they can provide their own. However, the most potent encouragement -- and the only available cncouragement in many independent language learning situations -- may come form inside the learner. Self-encouragement includes saying supportive things, prodding oneself to take risks wisely, and providing rewards.

\section{Making positive statements.}

Saying or writing positive statements to oneself in order to feel more confident in learning the new language.

\section{Taking risks wisely.}

Pushing oneself to take risks in a language learning situation, even though there is a chance of making a mistake or looking foolish. Risks must be tempered with good judgment.

\section{Rewarding yourself.}

Giving oneself a valuable reward for a particularly good performance in the new language.

\section{Taking Your Emotional Temperature}

The four strategies in this set help learners to assess their feelings, motivations, and attitudes and, in many cases, to relate them to language tasks. Unless learners know how they are feeling and why they are feeling that way, they are less able to control their affective side. The strategies in this set are particularly helpful for discerning negative attitudes and emotions that impede language learning progress. 
1. Listening to your body.

Paying attention to signals given by the body. These signals may be negative, reflecting stress, tension, worry, fear, and anger; or they may be positive, indicating happiness, interest, calmness, and pleasure.

2. Using a checklist.

Using a checklist to discover feelings, attitudes, and motivations concerning language learning in general, as well as concerning specific language tasks.

3. Writing a language learning diary.

Writing a diary or journal to keep track of events and feelings in the process of learning a new language.

4. Discussing your feelings with someone else.

Talking with another person (teacher, friend, relative) to discover and express feelings about language learning.

\section{Social Strategies}

Language is a form of social behavior, it is communication, and communication occurs between and among people. Learning a language thus involves other people, and appropriate social strategies are very important in this process.

\section{Asking Questions}

This set of strategies involves asking someone, possibly a teacher of native speaker or even a more proficient fellow learner, for clarification, verification, or correction.

\section{Asking for clarification or verification.}

Asking the speaker to repeat, paraphrase, explain, slow down, or give examples; asking if a specific utterance is correct or if a rule fits a particular case; paraphrasing or repeating to get feedback on whether something is correct. 


\section{Asking for correction}

Asking someone for correction in a conversation. This strategy most often occurs in conversation but may also be applied to writing.

\section{Cooperating with Others}

This set of two strategies involves interacting with one or more people to improve language skills. These strategies are the basis of cooperative language learning, which not only increases learners' language performance but also enhances self-worth and social acceptance.

\section{Cooperating with peers.}

Working with other language learners to improve language skills. This strategy can involve a regular learning partner or a temporary pair or small group. This strategy frequently involves controlling impulses toward competitiveness and rivalry.

2. Cooperating with proficient users of the new language.

Working with native speakers or other proficient users of the new language, usually outside of the language classroom. This strategy involves particular attention to the conversational roles each person takes.

\section{Empathizing with Others}

Empathy can be developed more easily when language learners use these two strategies.

\section{Developing cultural understanding.}

Trying to empathize with another person through learning about the culture, and trying to understand the other person's relation to that culture.

\section{Becoming aware of others' thoughts and feelings.}

Observing the behaviors of others as a possible expression of their thoughts and feelings; and when appropriate, asking about thoughts and feelings of others. 
APPENDIX B SILL SURVEY 


\title{
STRATEGY INVENTORY FOR LANGUAGE LEARNING (SILL)
}

\author{
Version for Speakers of Other Languages Learning English
}

\section{Version 7.0 (ESL/EFL)}

(c) R. Oxford 1989 (Oxford, 1990a, pp. 293-296)

\section{Directions}

This form of the STRATEGY INVENTORY FOR LANGUAGE LEARNING (SILL) is for students of English as a second or foreign language. You will find statements about learning English. Please read each statement. On the separate Worksheet, write the response $(1,2,3,4$, or 5 ) that tells HOW TRUE OF YOU THE STATEMENT IS.

1. Never or almost never true of me

2. Usually not true of me

3. Somewhat true of me

4. Usually true of me

5. Always or almost always true of me

NEVER OR ALMOST NEVER TRUE OF ME means that the statement is very rarely true of you.

USUALLY NOT TRUE OF ME means that the statement is true less than half the time.

SOMEWHAT TRUE OF ME means that the statement is true of you about half the time.

USUALLY TRUE OF ME means that the statement is true more than half the time.

ALWAYS OR ALMOST ALWAYS TRUE OF ME means that the statement is true of you almost always.

Answer in terms of how well the statement describes you. Do not answer how you think you should be, or what other people do. There are no right or wrong answers to these statements. Put your answers on the separate Worksheet. Please make no marks on the items. Work as quickly as you can without being careless. This usually takes about $20-30$ minutes to complete. If you have any questions, let the teacher know immediately. 


\section{EXAMPLE}

Read the item, and choose a response ( 1 through 5 above), and write it in the space after the item.

I actively seek out opportunities to talk with native speakers of English.

You have just completed the example item. Answer the rest of the items on the Worksheet.

\section{$\underline{\text { Part A }}$}

1. I think of relationships between what I already know and new things I learn in English.

2. I use new English words in a sentence so I can remember them.

3. I connect the sound of a new English word and an image or picture of the word to help me remember the word.

4. I remember a new English word by making a mental picture of a situation in which the word might be used.

5. I use rhymes to remember new English words.

6. I use flashcards to remember new English words.

7. I physically act out new English words.

8. I review English lessons often.

9. I remember new English words or phrases by remembering their location on the page, on the board, or on a street sign.

\section{$\underline{\text { Part B }}$}

10. I say or write new English words several times.

11. I try to talk like native English speakers.

12. I practice the sounds of English.

13. I use the English words I know in different ways.

14. I start conversations in English. 
15. I watch English language TV shows spoken in English or go to movies spoken in English.

16. I read for pleasure in English.

17. I write notes, messages, letters, or reports in English.

18. I first skim an English passage (read over the passage quickly) then go back and read carefully.

19. I look for words in my own language that are similar to new words in English.

20. I try to find patterns in English.

21. I find the meaning of an English word by dividing it into parts that I understand.

22. I try not to translate word-for-word.

23. I make summaries of information that I hear or read in English.

\section{$\underline{\text { Part C }}$}

24. To understand unfamiliar English words, I make guesses.

25. When I can't think of a word during a conversation in English, I use gestures.

26. I make up new words if I do not know the right ones in English.

27. I read English without looking up every new word.

28. I try to guess what the other person will say next in English.

29. If I can't think of an English word, I use a word or phrase that means the same thing.

\section{$\underline{\text { Part } D}$}

30. I try to find as many ways as I can to use my English.

31. I notice my English mistakes and use that information to help me do better. 
32. I pay attention when someone is speaking English.

33. I try to find out how to be a better learner of English.

34. I plan my schedule so I will have enough time to study English.

35. I look for people I can talk to in English.

36. I look for opportunities to read as much as possible in English.

37. I have clear goals for improving my English skills.

38. I think about my progress in learning English.

\section{$\underline{\text { Part E }}$}

39. I try to relax whenever I feel afraid of using English.

40. I encourage myself to speak English even when I am afraid of making a mistake.

41. I give myself a reward or treat when I do well in English.

42. I notice if I am tense or nervous when I am studying or using English.

43. I write down my feelings in a language learning diary.

44. I talk to someone else about how I feel when I am learning English.

\section{$\underline{\text { Part F }}$}

45. If I do not understand something in English, I ask the other person to slow down or say it again.

46. I ask English speakers to correct me when I talk.

47. I practice English with other students.

48. I ask for help from English speakers.

49. I ask questions in English.

50. I try to learn about the culture of English speakers. 
Date

Worksheet for Answering and Scoring

the Strategy Inventory for Language Learning (SILL)

Version 7.0 (ESL/EFL)

(c) R. Oxford, 1989 (Oxford, 1990a, pp. 297-298)

1. The blanks (__ ) are numbered for each item on the SILL.

2. Write your response to each item (that is, write $1,2,3,4$, or 5 ) in each of the blanks.

3. Add up each column. Put the result on the line makes SUM.

4. Divide by the number under SUM to get the average for each column. Round this average off to the nearest tenth, as in 3.4.

5. Figure out your overall average. To do this, add up all the SUMS for the different the different parts of the SILL. Then divide by 50 .

6. When you have finished, your teacher will give you the Profile of Results. Copy your averages (for each part and for the whole SILL) from the Worksheet to the Profile. 


\section{SLL Worksheet}

\section{Version 7.0 (ESL/EFL)}

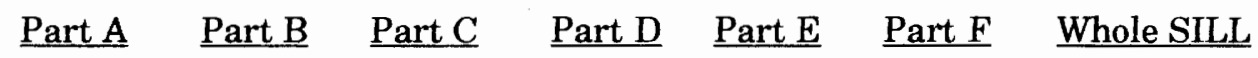

$$
1 .
$$

10.

24.

30.

39.

45.

SUM Part A

2.

25.

31.

40.

46.

SUM Part B

3.

12.

26.

32.

41.

47.

SUM Part C

4.

13.

27.

33.

42.

48.

SUM Part D

5.

14.

28.

34.

43.

49.

SUM Part E

$6 . \quad 15$

29.

35.

44.

50.

SUM Part F

7. 16.

36.

8.

17.

37.

9.

18.

38.

19.

20.

21.

22.

23.

\begin{tabular}{|c|c|c|c|c|c|c|}
\hline SUM & SUM & SUM & SUM & SUM & SUM & SUM \\
\hline$\div 9=$ & $\div 14=$ & $\div 6=$ & $\div 9=$ & $\div 6=$ & $\div 6=$ & $\div 50=$ \\
\hline
\end{tabular}


Your Name

Date

Profile of Results on the Strategy Inventory for Language Learning (SILL)

Version 7.0

(c) R. Oxford, 1989 (Oxford, 1990a, p. 299)

You will receive this Profile after you have completed the Worksheet. This Profile will show your SILL results. These results will tell you the kinds of strategies you use in learning English. There are no right or wrong answers.

To complete this profile, transfer your averages for each part of the SHL, and your overall average for the whole SILL. These averages are found on the Worksheet.

\section{Part What Strategies Are Covered Your Average on This Part}
A. Remembering more effectively
B. Using all your mental processes
C. Compensating for missing knowledge
D. Organizing and evaluating your learning
E. Managing your emotions
F. Learning with others

YOUR OVERALL AVERAGE 
Name

Date

Version 7.0

(c) R. Oxford, 1989 (Oxford, 1990a, p. 300)

\section{Key to Understanding Your Averages}

High

Always or almost always used $\quad 4.5$ to 5.0

Usually used

3.5 to 4.4

Medium Sometimes used

2.5 to 3.4

Generally not used

1.5 to 2.4

Low

Never or almost never used $\quad 1.0$ to 1.4

\section{Graph Your Averages Here}

If you want, you can make a graph of your SILL average. What does this graph tell you? Are you very high or very low on any part?

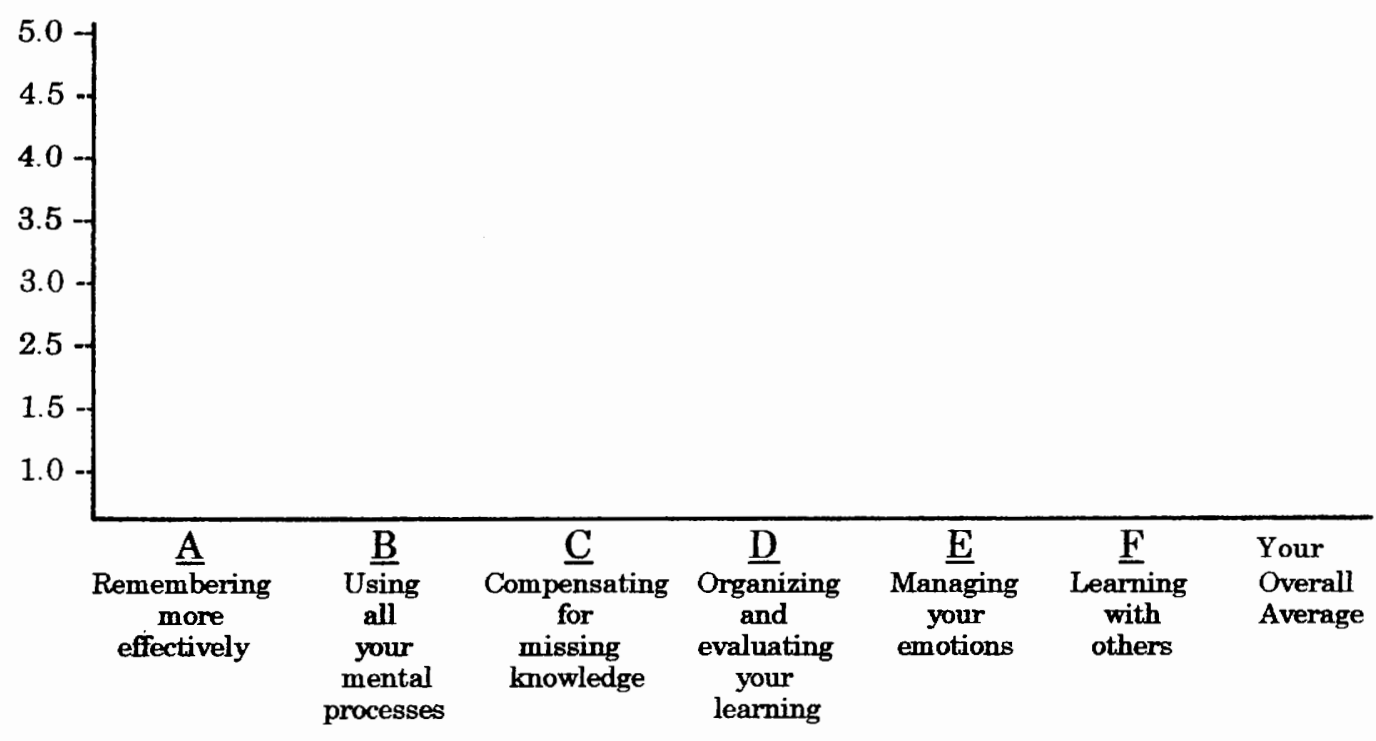

\section{What These Averages Mean to You}

The overall average tells how often you use strategies for learning English. Each part of the SILL represents a group of learning strategies. The averages for each part of the SILL show which groups of strategies you use the most for learning English.

The best use of strategies depends on your age, personality, and purpose for learning. If you have a very low average on one or more parts of the SILL, there may be some new strategies in these groups that you might want to use. Ask your teacher about these. 


\section{APPENDIX C SILL SURVEY (JAPANESE VERSION)}


Strategy Inventory for Language Learning (SILL)

Version7.0(ESL/EFL) (Oxford, 1990)

英語学習について該当する答え $(1 \sim 5)$ をワークシートに書いてくたさい。

1 全くまたはほとんど全く自分には該当しない。

2 通常自分には該当しない。（50\%以下）

3 いくぶかは自分に該当するといえる。（約 $50 \%$ ）

4 通常自分に該当する。（50\%以上）

$5100 \%$ \%たはほとど $100 \%$ 自分に該当するといえる。

Part A

1 英語を学ふ場合、既に知っている内容と新しく学んだこととの関係を考える。

2 新しい英単語を文章のなかで使い覚えようとする。

3 新しい英単語の音とイメージを結び付けて単語を覚えやすくする。

4 英単語を覚えるとき、頭のなかでその単語が使われる状況を思い浮かべる。

5 新しい英単語を覚えるために音䫓を使う。

6 新しい単語を覚えるためにカードを使う。

7 実際に体を使って新しい単語を覚えようとする。

8 度々英語の授業の復習をする。

9 単語やフレーズを覚えるとき、それらが使われているページや道路標識、 看板上のどこにあったかを思い浮かべたりする。

\section{Part B}

10 新しい単語を何度か畫いたりロに出したりしたりする。

11 英語を母国語としている人のように話そうと試す。

12 英語の音を練習する。

13 知っている単語をいろいろちがった使い方をする。

14 会話を英語で始める。

15 テレビの英語放送を見たり洋画を見に行ったりする。

16 楽しみのため英語で書かれたものを読む。 
17 伝言、手紙またはしボートなどを英語で書く。

18 英語で読むとき、まず全文にざっと目をとうし、その後注意しながら 再度読む。

19 新しく学ぶ英単語に似ている日本語の言枼を探す。

20 英語が持っているバターンを見つけようとする。

21 英単語の意味を自分の知っている部分に分けて考える。 （たとえば接頭語や接尾語など）

22 逐語訳しないようにする。

23 英語を聞いたり読んだりするとき、内容の要約を考える。

Part C

24 見慣れない単語を理解するのにいろいろ推測する。

25 英語で話していて言葉が思いつかない場合、ジェスチャーを使う。

26 適切な単語を思いつかないとき、自分で新しい単語を作り上げる。

27 英語を読んでいるとき、新しい単語ひとつひとつを辞書で調べずに読す。

28 英語で話しているとき、話し相手が次に何を言うか推測しようとする。

29 適当な単語を思いつかなとき、その同意語やつレーズを代りに使う。

Part D

30 英語を使えそうな機会をできるだけ多く得ようとする。

31 自分の英語の間違いに注意を向け、その間違いを英語力の向上に活用する。

32 他の人が英語を話しているのに注意を向ける。

33 どのようにしたらより良い英語学習者になれるか調べたりする。

34 計画を立て、英語学習に十分な時間をとれるようにする。

35 英語で会話できる相手を探す。

36 できるだけたくさんの英語を読めるような機会を得ようとする。

37 自分の英語力向上のための明確な目標を持っている。

38 自分の英語学習の進歩状況を考えたりする。 


\section{Part E}

39 英語を使うことが恐く感じるときはいつもリラックスしようと心がける。

40 間違うことが恐いと思っても自分を吨咤激励して英語を使うようにする。

41 英語が上手に使えたとき、自分自身に襄美を与えたりする。

42 英語を勉強したり話ししたりしている時、自分が緊張したり神経質になって いるかどうか気に留める。

43 語学学習日誌に自分の気持ちや感情を書き留める。

44 語学を学んでいるときの自分の気持ちや感情を他の人に話したりする。

\section{Part F}

45 分からない時、話し相手にゆっくり話してほしいとかもう一度言ってほしい と頼む。

46 英語を母国語としている人に自分の間違いを訂正してくれるよう頼む。

47 他の学習者と一緒に英語の練習をする。

48 英語を母国語としている人に助けを求める。

49 英語で質問する。

50 英語が話されている国々や人々の文化を学ぼうと心がける。 
氏名

日付

SILL (Version 7.0, (c) R. Oxford, 1989)

結果プロフィール

このプロフィールはワークシートを記入された後でお返しします。このプ ロフィールでS I L Lの結果が分かります。この結果であなたが英語をどう いう風に学んでいるかが分かります。回答にはいずれも正解や不正解はあり ません。

このプロフィールを記入されるにあたって、まずS I L Lの各パートの平 均点を記入して下さい。その後で） I L L 全体の平均点を計算してください。 各パートの平均点はワークシートにすでに記入されていますので、それを下 記に記入してください。

Part 英語の学び方 各パートの平均点
A . より効果的な記憶の仕方をしているか。
B. すべての知能的プロセスを働かせているか。
C. 欠けている知識を補っているか。
D. 自分の学習方法を評価しながら組み立てているか
E． 感情をうまくコントロールしているか。
F.ほかの人と一緒に学んでいるか。

総合平均点 
氏名 日付

SILL (Version 7.0, (c) R. Oxford, 1989)

結果フロフィール（前ページより続く）

平均点の読み方

高

常に、苦しくはほとんど常に使っている。

$4.5 \sim 5.0$

通常使っている。

$3.5 \sim 4.4$

中

時々使っている。

$2.5 \sim 3.4$

低

普通使っていない。

$1.5 \sim 2.4$

使っていない、若しくはほとんど使っていない。

$1.0 \sim 1.4$

平均点グラフ

下記にあなたのS I Lしの平均点のグラフを作ってみてください。このグラフから何が わかりますか? あるハーードずば抜けて高かったり、あるいは低かったりしていますか?

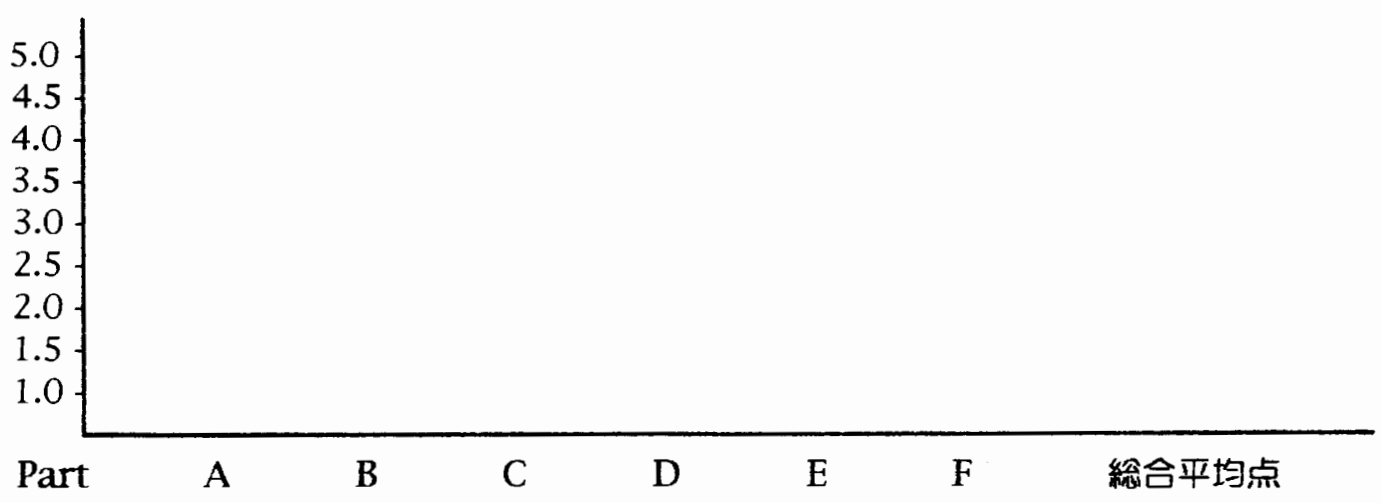

平均点をどう読むか

全体の平均点からどれぐらいの頻度であなたが英語を学習している时に何らかの学び方手法を用い ているかがわかります。ＩＬしの各バートはあるタイブの学び方を用いているかを調べています。 S 1 Lしの各パートの平均点を比べることでどのタイプの学び方をあなたが最も活角しているかがわ かります。

どのタイブの学び方があなたに最も適しているかは、あなたの年柃、性格、および英語を学ら泪的 によって異なります。もしS1 L Lの中で平均点が他に比べて非常に低いバートがあれは、そのハー 上の中にあがっている学ひ方を活用されてみてもいいでしょう。先生にも学び方について意見を同っ てください。 
APPENDIX D

CARD RANKING ACTIVITY

(JAPANESE VERSION) 
CARD RANKING ACTIVITY: INSTRUCTION IN JAPANESE

皆さんのアメリカでの経験に関するアクテ代ティです。皆さんは、アメ リカでどんな経験をされたでしょうか？ 素晴しい経験だったり、また はその反刘にいやな経験だったり、いろいろな経験をされたと思います が、皆さんのアメリカでの毎日の生活也学校での経験について思い出し てください。

（1）まず、40のカードから「一番いやだった、心配だった、または 残念だった」"negative"な経験として10のカードを選んでください。 次に、選ばれた 10 のカードの経験の中で、その度合に応じて、一番強 く"negative"に感じた順に100カードをランキングしてください。順位 が決まりましたら、"Most negative" 1 から "Least negative" 10 まで順 位どおりに番号を回答シートに記入してください。記入が終わりました ら、選んだ 10 のカードをほかのカードと一緒にしてください。

（2）今回は、（1）とは反刘で、「一番うれしかった、良かった、ま たは感激した」"positive"な経験として10のカードを40のカードから 選んでいただきます。（1）で選ばれた番号がここで再度選ばれること も考えられます。これは、同じような経験で、両極端のの経験をされて いることを意味します。10のカードが選ばれましたら、その度合に応 じて、一番強く"positive"に感じた順に100カードをランキングしてく ださい。順位が決まりましたら、"Most positive" 1 から"Least positive" 10 まで順位どおりに番号を回答シートに記入してください。 
Card Ranking Activity: Forty Subcategories

(Japanese translation)

\begin{tabular}{|c|c|c|}
\hline $\begin{array}{c}1 \\
\text { 成 績 結 果 }\end{array}$ & $\begin{array}{c}2 \\
\text { 日本人としての } \\
\text { 認 } \\
\text { 識 }\end{array}$ & $\begin{array}{c}3 \\
\text { ホームシック }\end{array}$ \\
\hline $\begin{array}{l}\text { 自己 }{ }^{4} \text { 啓 発 } \\
\text { (日本人学生やアメリカ人 } \\
\text { との交流をとおして) } \\
\end{array}$ & $\begin{array}{c}5 \\
\text { 英語力の上達 } \\
\text { 期待と現実との } \\
\text { ギャップ }\end{array}$ & $\begin{array}{c}6 \\
\text { 自己再発見 }\end{array}$ \\
\hline $\begin{array}{c}7 \\
\text { 英 文 法 力 }\end{array}$ & $\begin{array}{c}8 \\
\text { 異なった考え方／ } \\
\text { 物の見方 }\end{array}$ & $\begin{array}{c}\quad 9 \\
\text { PSU undergraduate } \\
\text { のプログラム }\end{array}$ \\
\hline $\begin{array}{c}10 \\
\text { いろいろなことに } \\
\text { 初挑 戦 } \\
\text { (自分の款を破る) }\end{array}$ & $\begin{array}{l}11 \\
\text { 自分と他の同級生 } \\
\text { との比較 }\end{array}$ & $\begin{array}{c}12 \\
\text { 英語の発音 } \\
\text { (声の大きさなども含む) }\end{array}$ \\
\hline $\begin{array}{c}13 \\
\text { 英語力の維持 } \\
\text { (日本帰国後) }\end{array}$ & $\begin{array}{c}14 \\
\text { 英語による } \\
\text { コミュニーション } \\
\text { 買い物/バス/街/電話 }\end{array}$ & $\begin{array}{l}15 \\
\text { 自分の人間として } \\
\text { の成長 }\end{array}$ \\
\hline $\begin{array}{c}16 \\
\text { アメリカでの残り滞在 } \\
\text { 期間の時間の使い方 }\end{array}$ & $\begin{array}{c}17 \\
\text { 英語読解力 }\end{array}$ & 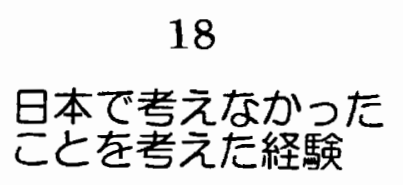 \\
\hline $\begin{array}{c}\text { クラスのプロジェクト } \\
\text { presentation/speech } \\
\text { interview/discussion } \\
\text { homework }\end{array}$ & $\begin{array}{l}20 \\
\text { ホストファミリーとの } \\
\text { コミュニケーションや } \\
\text { 人間関係 }\end{array}$ & $\begin{array}{c}21 \\
\text { PSU ESL } \\
\text { プログラム }\end{array}$ \\
\hline
\end{tabular}




\begin{tabular}{|c|c|c|}
\hline $\begin{array}{c}22 \\
\text { 日本へ帰ること }\end{array}$ & $\begin{array}{c}23 \\
\text { 単語力／熟語力 }\end{array}$ & 友人関係 \\
\hline 25 & 26 & 27 \\
\hline $\begin{array}{l}\text { 授業の進め方 } \\
\text { (日本vs.アメリカ) }\end{array}$ & 英語による感情表現 & スピーキング能力 \\
\hline 28 & 29 & 30 \\
\hline 自分 の 性 格 & $\begin{array}{l}\text { 教師や他の人達からの } \\
\text { アドバイスや励まし }\end{array}$ & $\begin{array}{c}\text { Conversation partner } \\
\text { との交流 }\end{array}$ \\
\hline $\begin{array}{c}31 \\
\text { 英語学習の仕方 }\end{array}$ & $\begin{array}{c}32 \\
\text { ルームメイトとの } \\
\text { 人間闋係/分パート } \\
\text { での共同生活 }\end{array}$ & $\begin{array}{c}33 \\
\text { ライティング能力 }\end{array}$ \\
\hline $\begin{array}{c}34 \\
\text { 文化/習慣のちがい } \\
\text { (日本vs.アメリカ) }\end{array}$ & $\begin{array}{l}\text { 35 } \\
\text { 自分の㸹来 } \\
\text { (就職活動等卒業後 } \\
\text { の方針) }\end{array}$ & $\begin{array}{c}36 \\
\text { アメリカでの人種差別 } \\
\text { や偏見 }\end{array}$ \\
\hline 37 & 38 & 39 \\
\hline ヒアリング能力 & $\begin{array}{l}\text { 大手前プログラム } \\
\text { の内容 (PSUでの) }\end{array}$ & 日本 /日本文化の知識 \\
\hline $\begin{array}{l}40 \\
\text { 留学への期待と現実 } \\
\text { とのギャップ }\end{array}$ & & \\
\hline
\end{tabular}


APPENDLX E SUBCATEGORY LIST: DIALOGUE JOURNALS 


\section{Subcategory List: Dialogue Journals}

Card\#
\begin{tabular}{|l|l|}
\hline C1 & Grades \\
\hline C2 & Self recognition as Japanese \\
\hline C3 & Homesickness \\
\hline C4 & Self improvement through communication in the US \\
\hline C5 & Gap between expectation and reality of English improvement \\
\hline C6 & Discover "self' \\
\hline C7 & English grammar skills \\
\hline C8 & Different ways of thinking and perceiving \\
\hline C9 & PSU undergraduate program \\
\hline C10 & Challenging various new things \\
\hline C11 & Comparing myself with other classmates and feeling inferior/jealous \\
\hline C12 & English pronunciation, including voice projection \\
\hline C13 & Keeping up English abilities after returning to Japan \\
\hline C14 & Everyday communication (shopping, bus, street, telephone, etc.) \\
\hline C15 & Personal growth \\
\hline C16 & How to spend time in the US until leaving \\
\hline C17 & Reading skills \\
\hline C18 & Thinking about what I never thought about before \\
\hline C19 & Class projects (presentation, speech, interview, discussion, homework) \\
\hline C20 & Communication and relationships with host family \\
\hline C21 & PSU ESL program \\
\hline C22 & Returning to Japan \\
\hline C23 & Vocabulary / idiom skills \\
\hline C24 & Relationships with friends \\
\hline C25 & Lesson/classroom procedure (in Japan vs. in US) \\
\hline C26 & Expressing feelings in English \\
\hline C27 & Speaking skills \\
\hline C28 & My personality / character \\
\hline C29 & Encouragement and/or advice from teachers and others \\
\hline C30 & Communication and relationships with conversation partners \\
\hline C31 & How to improve/study English \\
\hline C32 & Relationships with roommates; living together in an apartment \\
\hline C33 & Writing skills \\
\hline C34 & Culture and tradition difference \\
\hline C35 & Future plans after graduating from school (job hunting in Japan, etc. \\
\hline C36 & Racial discrimination / prejudice \\
\hline C37 & Listening skills \\
\hline C38 & Otemae program at PSU \\
\hline C39 & Knowledge of Japan and its culture \\
\hline C40 & Gap between the reality and expectation of studying in US \\
\hline
\end{tabular}




\section{APPENDIX F \\ SILL RESULTS: \\ COMPARISON OF ALL MEDIAN SCORES \\ BETWEEN SILLs \#1 AND \#2}


Wilcoxon Matched-Pairs Signed-Ranks Test:

Median Score Comparison between SILLs \#1 (L1) and \#2 (L2)

[ST \& LT Groups, n=40]

\begin{tabular}{|c|c|c|c|}
\hline Part A & $\# 1$ & $\# 2$ & P value \\
\hline Total & $\mathbf{3 . 0}$ & $\mathbf{3 . 0}$ & $.0115^{* *}$ \\
\hline Q 1 & 3.0 & 3.0 & .0425 \\
\hline Q 2 & $\mathbf{3 . 0}$ & $\mathbf{4 . 0}$ &. $\mathbf{0 0 4 2}^{*}$ \\
\hline Q 3 & 3.0 & 3.0 & .5857 \\
\hline Q 4 & $\mathbf{3 . 0}$ & $\mathbf{4 . 0}$ & $.0004^{*}$ \\
\hline Q 5 & 2.0 & 2.0 & .8022 \\
\hline Q 6 & $\mathbf{3 . 0}$ & $\mathbf{2 . 0}$ & $.0163^{*}$ \\
\hline Q 7 & $\mathbf{2 . 0}$ & $\mathbf{3 . 0}$ & $.0006^{*}$ \\
\hline Q 8 & 3.0 & 3.0 & .7317 \\
\hline Q 9 & $\mathbf{3 . 0}$ & $\mathbf{4 . 0}$ & $.0190^{*}$ \\
\hline
\end{tabular}

\begin{tabular}{|c|c|c|c|}
\hline Part D & $\# 1$ & $\# 2$ & P value \\
\hline Total & 3.0 & 4.0 & .0203 \\
\hline Q 30 & $\mathbf{3 . 0}$ & $\mathbf{4 . 0}$ &. $\mathbf{0 0 0 2}$ \\
\hline Q 31 & 3.0 & 4.0 & .1924 \\
\hline Q 32 & 5.0 & 4.5 & .6051 \\
\hline Q 33 & 2.0 & 3.0 & .0754 \\
\hline Q 34 & 2.0 & 2.0 & .7064 \\
\hline Q 35 & $\mathbf{2 . 0}$ & $\mathbf{4 . 0}$ &. $\mathbf{0 0 0 1}$ \\
\hline Q 36 & 3.0 & 3.0 & .1529 \\
\hline Q 37 & 4.0 & 3.0 & .4781 \\
\hline Q 38 & $\mathbf{4 . 0}$ & $\mathbf{4 . 5}$ & $.0012 *$ \\
\hline
\end{tabular}

\begin{tabular}{|c|c|c|c|}
\hline Part B & $\# 1$ & $\# 2$ & P value \\
\hline Total & $\mathbf{3 . 0}$ & 4.0 & C.0001 $^{* *}$ \\
\hline Q 10 & 4.0 & 4.0 & .9544 \\
\hline Q 11 & $\mathbf{3 . 0}$ & 4.0 & $.0003^{*}$ \\
\hline Q 12 & $\mathbf{3 . 0}$ & 4.0 & $.0032^{*}$ \\
\hline Q 13 & 2.0 & $\mathbf{3 . 0}$ & $.0025^{*}$ \\
\hline Q 14 & $\mathbf{2 . 0}$ & $\mathbf{3 . 0}$ & $\mathbf{6 0 0 0 1 ^ { * }}$ \\
\hline Q 15 & 4.0 & $\mathbf{5 . 0}$ & $.0062^{*}$ \\
\hline Q 16 & $\mathbf{3 . 0}$ & $\mathbf{3 . 0}$ & $.0224^{*}$ \\
\hline Q 17 & $\mathbf{2 . 0}$ & $\mathbf{3 . 0}$ & $\mathbf{6 0 0 0 1 ^ { * }}$ \\
\hline Q 18 & $\mathbf{4 . 0}$ & $\mathbf{4 . 0}$ & $.0055^{*}$ \\
\hline Q 19 & 2.0 & 2.0 & .8329 \\
\hline Q 20 & 3.0 & 3.0 & .0829 \\
\hline Q 21 & 3.0 & 3.0 & .6476 \\
\hline Q 22 & $\mathbf{3 . 0}$ & 4.0 & $.0002^{*}$ \\
\hline Q 23 & 4.0 & 4.0 & .2326 \\
\hline
\end{tabular}

\begin{tabular}{|c|c|c|c|}
\hline Part E & $\# 1$ & $\# 2$ & $P$ value \\
\hline Total & 2.5 & $\mathbf{3 . 5}$ & $.0008^{* *}$ \\
\hline Q39 & $\mathbf{3 . 0}$ & 4.0 & $.0014^{*}$ \\
\hline Q40 & 3.0 & 4.0 & $.0002^{*}$ \\
\hline Q41 & 3.0 & 4.0 & $.0053^{*}$ \\
\hline $\mathrm{Q} 42$ & 2.0 & 3.0 & .0578 \\
\hline Q 43 & 2.0 & 2.0 & .0675 \\
\hline Q 44 & 3.0 & 4.0 & .0333 \\
\hline
\end{tabular}

\begin{tabular}{|c|c|c|c|}
\hline Part F & $\# 1$ & $\# 2$ & P value \\
\hline Total & 2.0 & 4.0 & C.0001** $^{*}$ \\
\hline Q45 & 4.0 & 4.0 & $.0013^{*}$ \\
\hline Q46 & 2.0 & 3.0 & $.0001^{*}$ \\
\hline Q47 & 2.0 & 3.0 & $.0058^{*}$ \\
\hline Q48 & 2.0 & 4.0 & $<0001^{*}$ \\
\hline Q49 & 2.0 & 4.0 & $<0001^{*}$ \\
\hline Q50 & 4.0 & 4.0 & $.0136^{*}$ \\
\hline
\end{tabular}

\begin{tabular}{|c|c|c|c|}
\hline Part C & $\# 1$ & $\# 2$ & P value \\
\hline Total & $\mathbf{3 . 5}$ & $\mathbf{4 . 5}$ & $\mathbf{K 0 0 0 1 ^ { * * }}$ \\
\hline Q 24 & 3.0 & 3.0 & .0310 \\
\hline Q 25 & 3.0 & 4.0 & .1005 \\
\hline Q26 & $\mathbf{3 . 0}$ & $\mathbf{3 . 0}$ & $.0174^{*}$ \\
\hline Q27 & $\mathbf{3 . 0}$ & $\mathbf{4 . 0}$ & $.0085^{*}$ \\
\hline Q28 & $\mathbf{2 . 0}$ & $\mathbf{2 . 0}$ & $\mathbf{C 0 0 0 1}^{*}$ \\
\hline $\mathbf{Q 2 9}^{*}$ & $\mathbf{3 . 0}$ & $\mathbf{2 . 0}$ & $.0064^{*}$ \\
\hline
\end{tabular}

* [Question] significant at $\mathrm{P}=<.250$

** [Total $]$ significant at $\mathrm{P}=<.0167$ 


\section{APPENDIX G \\ DIALOGUE JOURNAL DATA \\ (SPRING AND SUMMER TERMS)}


THREE LEADING SUBCATEGORIES IN SIX CATEGORIES TOTAL SPRING SUMMER

\begin{tabular}{c|c|c|c}
\hline ENGLISH LEARNING & $(104)$ & $(76)$ & $(28)$ \\
\hline Grammar skills & $\begin{array}{c}24.0 \% \\
(25)\end{array}$ & $\begin{array}{c}30.3 \% \\
(23)\end{array}$ & $\begin{array}{c}7.1 \% \\
(2)\end{array}$ \\
\hline How to study English & $\begin{array}{c}20.2 \% \\
(21)\end{array}$ & $\begin{array}{c}18.4 \% \\
(14)\end{array}$ & $\begin{array}{c}25.0 \% \\
(7)\end{array}$ \\
\hline Speaking skills & $\begin{array}{c}19.2 \% \\
(20)\end{array}$ & $\begin{array}{c}15.8 \% \\
(12)\end{array}$ & $\begin{array}{c}28.6 \% \\
(8)\end{array}$ \\
\hline
\end{tabular}

\begin{tabular}{|c|c|c|c|}
\hline $\begin{array}{l}\text { COMMUNICATION \& } \\
\text { RELATIONSHIPS }\end{array}$ & (95) & (81) & (14) \\
\hline $\begin{array}{l}\text { Communication \& relation- } \\
\text { ships with host family }\end{array}$ & $\begin{array}{c}37.9 \% \\
(36)\end{array}$ & $\begin{array}{c}38.3 \% \\
(31)\end{array}$ & $\begin{array}{l}35.7 \% \\
(5)\end{array}$ \\
\hline Everyday communication & $\begin{array}{l}23.2 \% \\
(22) \\
\end{array}$ & $\begin{array}{c}25.9 \% \\
(21) \\
\end{array}$ & $\begin{array}{c}7.1 \% \\
(1) \\
\end{array}$ \\
\hline $\begin{array}{l}\text { Encouragement \& advice } \\
\text { from teachers and others }\end{array}$ & $\begin{array}{c}18.9 \% \\
(18)\end{array}$ & $\begin{array}{c}18.5 \% \\
(15)\end{array}$ & $\begin{array}{c}21.4 \% \\
(3)\end{array}$ \\
\hline
\end{tabular}

\begin{tabular}{l|c|c|c}
\hline SELF IMPROVEMENT & $(68)$ & $(37)$ & $(31)$ \\
\hline $\begin{array}{l}\text { Challenging various new } \\
\text { things }\end{array}$ & $\begin{array}{c}39.7 \% \\
(27)\end{array}$ & $\begin{array}{c}45.9 \% \\
(17)\end{array}$ & $\begin{array}{c}32.3 \% \\
(10)\end{array}$ \\
\hline $\begin{array}{l}\text { Self development through } \\
\text { communication with people }\end{array}$ & $\begin{array}{c}22.1 \% \\
(15)\end{array}$ & $\begin{array}{c}24.3 \% \\
(9)\end{array}$ & $\begin{array}{c}19.4 \% \\
(6)\end{array}$ \\
\hline $\begin{array}{l}\text { Comparing myself with other } \\
\text { classmates and feeling }\end{array}$ & $14.7 \%$ & $10.8 \%$ & $19.4 \%$ \\
jealous & $(10)$ & $(4)$ & $(6)$ \\
\hline
\end{tabular}


TOTAL SPRING SUMMER

\begin{tabular}{l|c|c|c}
\hline CULTURE RELATED ISSUES & $(36)$ & $(22)$ & $(14)$ \\
\hline $\begin{array}{l}\text { Thinking about what I never } \\
\text { thought about before }\end{array}$ & $\begin{array}{c}33.3 \% \\
(12)\end{array}$ & $\begin{array}{c}27.3 \% \\
(6)\end{array}$ & $\begin{array}{c}42.9 \% \\
(6)\end{array}$ \\
\hline $\begin{array}{l}\text { Different ways of thinking/ } \\
\text { perceiving }\end{array}$ & $\begin{array}{c}30.6 \% \\
(11)\end{array}$ & $\begin{array}{c}22.7 \% \\
(5)\end{array}$ & $\begin{array}{c}42.9 \% \\
(6)\end{array}$ \\
\hline $\begin{array}{l}\text { Culture \& tradition } \\
\text { difference }\end{array}$ & $\begin{array}{c}19.4 \% \\
(7)\end{array}$ & $\begin{array}{c}31.8 \% \\
(7)\end{array}$ & \begin{tabular}{c}
$(0)$ \\
\hline
\end{tabular}
\end{tabular}

\begin{tabular}{l|c|c|c}
\hline SCHOOL RELATED ISSUES & $(33)$ & $(12)$ & $(21)$ \\
\hline PSU ESL program & $\begin{array}{c}36.4 \% \\
(12)\end{array}$ & $\begin{array}{c}8.3 \% \\
(1)\end{array}$ & $\begin{array}{c}52.4 \% \\
(11)\end{array}$ \\
\hline $\begin{array}{l}\text { Class projects } \\
\text { (presentation, etc.) }\end{array}$ & $\begin{array}{c}30.3 \% \\
(10)\end{array}$ & $\begin{array}{c}33.3 \% \\
(4)\end{array}$ & $\begin{array}{c}28.6 \% \\
(6)\end{array}$ \\
\hline $\begin{array}{l}\text { Lesson/classroom procedure } \\
\text { (US vs. Japan) }\end{array}$ & $\begin{array}{c}15.2 \% \\
(5)\end{array}$ & $\begin{array}{c}25.0 \% \\
(3)\end{array}$ & $\begin{array}{c}9.5 \% \\
(2)\end{array}$ \\
\hline
\end{tabular}

\begin{tabular}{l|c|c|c}
\hline EXPECTATION \& REALITY & $(19)$ & $(7)$ & $(12)$ \\
\hline $\begin{array}{l}\text { Gap between expectations \& } \\
\text { reality of Eng. improvement }\end{array}$ & $\begin{array}{c}42.1 \% \\
(8)\end{array}$ & $\begin{array}{c}57.1 \% \\
(4)\end{array}$ & $\begin{array}{c}33.3 \% \\
(4)\end{array}$ \\
\hline How to spend time in the US & $\begin{array}{c}21.1 \% \\
(4)\end{array}$ & $\begin{array}{c}14.3 \% \\
(1)\end{array}$ & $\begin{array}{c}25.0 \% \\
(3)\end{array}$ \\
\hline $\begin{array}{l}\text { Keeping up English abilities } \\
\text { after returning to Japan }\end{array}$ & $\begin{array}{c}15.8 \% \\
(3)\end{array}$ & $\begin{array}{c}- \\
(0)\end{array}$ & $\begin{array}{c}25.0 \% \\
(3)\end{array}$ \\
\hline
\end{tabular}




\section{APPENDIX $\mathrm{H}$}

\section{CARD RANKING ACTIVITY RESULTS}


The LT Group students [ $n=14$ ]

\begin{tabular}{|c|c|c|c|c|}
\hline \multicolumn{2}{|c|}{$\begin{array}{c}\text { NEGATIVE } \\
\text { EMOTIONS/EXPERIENCES } \\
\end{array}$} & & \multicolumn{2}{|c|}{$\begin{array}{c}\text { POSITIVE } \\
\text { EMOTIONS/EXPERIENCES } \\
\end{array}$} \\
\hline Median & \# of Students & Card \# & \# of Students & Median \\
\hline 10.0 & 1 & C1 & 1 & 10.0 \\
\hline 10.0 & 5 & $\mathrm{C} 2$ & 5 & 9.0 \\
\hline 3.0 & 3 & $\mathrm{C} 3$ & 1 & 7.0 \\
\hline$m$ & 0 & $\mathbf{C 4}$ & $9(64.3 \%)$ & 6.0 \\
\hline 3.5 & $10(71.4 \%)$ & C5 & 0 & \\
\hline 9.0 & 1 & C6 & $8(57.1 \%)$ & 6.5 \\
\hline 3.1 & 1 & $\mathrm{C} 7$ & 0 & \\
\hline 5.5 & 2 & $\mathbf{C 8}$ & $9(64.3 \%)$ & 6.0 \\
\hline 6.5 & 2 & $\mathrm{C9}$ & 5 & 6.0 \\
\hline 9.0 & 3 & $\mathbf{C 1 0}$ & $10(71.4 \%)$ & 5.0 \\
\hline 3.0 & 5 & C11 & 0 & - \\
\hline 6.0 & 3 & C12 & 3 & 10.0 \\
\hline 6.0 & 5 & C13 & 0 & $=$ \\
\hline 7.0 & 3 & $\overline{\mathrm{C14}}$ & $7(50.0 \%)$ & 7.0 \\
\hline 8.0 & 3 & $\mathrm{C15}$ & $11(78.6 \%)$ & 5.0 \\
\hline 6.0 & 3 & C16 & 0 & - \\
\hline 5.0 & 1 & C17 & 0 & - \\
\hline & 0 & $\mathrm{C18}$ & $10(71.4 \%)$ & $\mathbf{3 . 5}$ \\
\hline 7.5 & 2 & C19 & 2 & 6.5 \\
\hline 3.0 & 4 & C20 & $9(64.3 \%)$ & 3.0 \\
\hline 5.5 & 2 & C21 & 1 & 5.0 \\
\hline $\mathbf{3 . 0}$ & $7(50.0 \%)$ & $\mathbf{C 2 2}$ & 1 & 5.0 \\
\hline 7.0 & 3 & $\mathrm{C} 23$ & 0 & 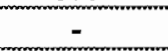 \\
\hline 2.0 & 3 & $\mathbf{C 2 4}$ & $10(71.4 \%)$ & 4.0 \\
\hline 4.0 & 1 & $\mathrm{C25}$ & $\frac{1}{3}$ & 9.0 \\
\hline 5.0 & $8(57.1 \%)$ & C26 & 1 & 8.0 \\
\hline 5.0 & $7(50.0 \%)$ & C27 & 1 & 7.0 \\
\hline 4.0 & 5 & $\mathrm{C} 28$ & 2 & 6.0 \\
\hline 9.0 & 1 & C29 & $11(78.6 \%)$ & 3.0 \\
\hline- & 0 & C30 & 3 & 4.0 \\
\hline 7.5 & 2 & C31 & 1 & 6.0 \\
\hline 6.0 & 5 & C32 & 6 & 2.5 \\
\hline & 0 & $\mathrm{C} 33$ & 0 & - \\
\hline 9.0 & 3 & C34 & 4 & 9.0 \\
\hline 5.0 & $7(50.0 \%)$ & C35 & 3 & 5.0 \\
\hline 4.5 & 6 & $\mathrm{C36}$ & 0 & - \\
\hline 3.0 & 4 & C37 & 1 & 6.0 \\
\hline 6.0 & 5 & $\mathrm{C} 38$ & 1 & 7.0 \\
\hline 7.0 & $9(64.3 \%)$ & C39 & 1 & 10.0 \\
\hline 5.0 & 5 & C40 & 0 & \\
\hline
\end{tabular}


LT Group students [ $n=14$ ]

Negative Emotions and Experiences

\begin{tabular}{|c|c|c|c|}
\hline Rank & \# of Ss & Median & Subcategory \\
\hline 1 & 10 & 3.5 & Gap between expect. \& reality of Eng. improvement [C5] \\
\hline 2 & 9 & 7.0 & Knowledge of Japan and its culture [C39] \\
\hline 3 & 8 & 5.0 & Expressing feelings in English [C26] \\
\hline 4 & 7 & 3.0 & Returning to Japan [C22] \\
\hline \multirow[t]{2}{*}{5} & 7 & 5.0 & Future plans after graduating from school [C35] \\
\hline & 7 & 5.0 & Speaking skills [C27] \\
\hline 7 & 6 & 4.5 & Racial discrimination/prejudice [C36] \\
\hline 8 & 5 & 3.0 & Comparison between self \& others [C11] \\
\hline $\mathbf{9}$ & 5 & 4.0 & Self personality / character [C28] \\
\hline 10 & 5 & 5.0 & Gap between reality \& expect. of studying in US [C40] \\
\hline \multirow[t]{3}{*}{11} & 5 & 6.0 & Relationships $w /$ roommates;living together in apt [C32] \\
\hline & 5 & 6.0 & Keeping up Eng. abilities after returning to Japan [C13] \\
\hline & 5 & 6.0 & Otemae program at PSU [C38] \\
\hline 14 & 5 & 10.0 & Self recognition as Japanese [C2] \\
\hline \multirow[t]{2}{*}{15} & 4 & 3.0 & Listening skills [C37] \\
\hline & 4 & 3.0 & Communication \& relationships with host family $[\mathrm{C} 20]$ \\
\hline 17 & 3 & 2.0 & Relationships with friends [C24] \\
\hline 18 & 3 & 3.0 & Homesickness [C3] \\
\hline \multirow[t]{2}{*}{19} & 3 & 6.0 & How to spend time in US until leaving [C16] \\
\hline & 3 & 6.0 & English pronunciation [C12] \\
\hline \multirow[t]{2}{*}{21} & 3 & 7.0 & Vocabulary/idiom skills [C23] \\
\hline & 3 & 7.0 & Everyday communication [C14] \\
\hline 23 & 3 & 8.0 & Personal growth [C15] \\
\hline \multirow[t]{2}{*}{24} & 3 & 9.0 & Culture \& tradition differences [C34] \\
\hline & 3 & 9.0 & Challenging new things $[\mathrm{C} 10]$ \\
\hline 26 & 2 & 5.5 & Different ways of thinking and perceiving [C8] \\
\hline 27 & 2 & 6.5 & PSU undergraduate program [C9] \\
\hline \multirow[t]{3}{*}{28} & 2 & 7.5 & Class projects (presentation, speech, etc.) [C19] \\
\hline & 2 & 7.5 & PSU ESL program [C21] \\
\hline & 2 & 7.5 & How to study/improve English (in general) [C31] \\
\hline 31 & 1 & 3.0 & English grammar skills [C7] \\
\hline 32 & 1 & 4.0 & Lesson/classroom procedure (Japan vs. US) [C25] \\
\hline 33 & 1 & 5.0 & Reading skills [C17] \\
\hline \multirow[t]{2}{*}{34} & 1 & 9.0 & Discover "self" [C6] \\
\hline & 1 & 9.0 & Encouragement, advice from teachers \& others [C29] \\
\hline \multirow[t]{5}{*}{36} & 1 & 10.0 & Grades [C1] \\
\hline & 0 & - & Self improvement through communication [C4] \\
\hline & 0 & - & Thinking about what I never thought about before [C18] \\
\hline & $\mathbf{0}$ & - & $\begin{array}{l}\text { Communication \& relationships w/ conversation partners } \\
\text { [C30] }\end{array}$ \\
\hline & 0 & 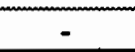 & Writing skills [C33] \\
\hline
\end{tabular}


The LT Group Students [ $n=14]$

Positive Emotions and Experiences

\begin{tabular}{|c|c|c|l|}
\hline Rank & \# of Ss & Median & \\
\hline 1 & 11 & 3.0 & Encouragement, advice from teachers and others [C29] \\
\hline 2 & 11 & 5.0 & Personal growth [C15] \\
\hline 3 & 10 & 3.5 & Thinking about what I never thought about before [C18] \\
\hline 4 & 10 & 4.0 & Relationships with friends [C24] \\
\hline 5 & 10 & 5.0 & Challenging various new things [C10] \\
\hline 6 & 9 & 3.0 & Communication \& relationships with host family [C20] \\
\hline 7 & 9 & 6.0 & Self improvement through communication [C4] \\
\hline 8 & 9 & 6.0 & Different ways of thinking / perceiving [C8] \\
\hline 9 & 8 & 6.5 & Discover "self" [C6] \\
\hline 10 & 7 & 7.0 & Everyday communication [C14] \\
\hline 11 & 6 & 2.5 & Relationships with roommates; living together in apt. [C32] \\
\hline 12 & 5 & 6.0 & PSU undergraduate programs [C9] \\
\hline 13 & 5 & 9.0 & Self recognition as Japanese [C2] \\
\hline 14 & 4 & 9.0 & Culture \& tradition differences [C34] \\
\hline 15 & 3 & 4.0 & Communication \& relationships with conversation partner [C30] \\
\hline 16 & 3 & 5.0 & Future plans after graduating from school [C35] \\
\hline 17 & 3 & 9.0 & Lesson/classroom procedure (Japan vs. US) [C25] \\
\hline 18 & 3 & 10.0 & English pronunciation [C12] \\
\hline 19 & 2 & 6.0 & Self personality/ character [C28] \\
\hline 20 & 2 & 6.5 & Class projects (presentation, speech, etc.) [C19] \\
\hline 21 & 1 & 5.0 & Returning to Japan [C22] \\
\hline & 1 & 5.0 & PSU ESL program [C21] \\
\hline 23 & 1 & 6.0 & How to study/improve English [C31] \\
\hline & 1 & 6.0 & Listening skills [C37] \\
\hline & 1 & 6.0 & Otemae program at PSU [C38] \\
\hline 26 & 1 & 7.0 & Homesickness [C3] \\
\hline & 1 & 7.0 & Speaking skills [C27] \\
\hline 28 & 1 & 8.0 & Expressing feelings in English [C26] \\
\hline 29 & 1 & 10.0 & Grades [C1] \\
\hline & 1 & 10.0 & Knowledge of Japan and its culture [C39] \\
\hline & 0 & - & Gap between expectation \& reality of Eng. improvement [C5] \\
\hline & 0 & - & English grammar skills [C7] \\
\hline & 0 & - & Comparison between self and others [C11] \\
\hline & 0 & - & Leeping up English abilities after returning to Japan [13] \\
\hline & 0 & - & How to spend time in the US until leaving [C16] \\
\hline & 0 & - & Reading skills [C17] \\
\hline & 0 & - & Vocabulary/ idiom skills [C23] \\
\hline & 0 & - & Writing skills [C33] \\
\hline & 0 & - & Racial discrimination/prejudice [C36] \\
\hline & 0 & - & Gap between reality \& expectation of studying in US [C40] \\
\hline & & & \\
\hline & &
\end{tabular}


ST Group Students [n=17]
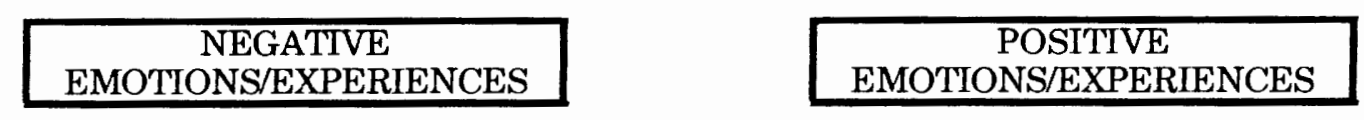

\begin{tabular}{|c|c|c|c|c|}
\hline Median & \# of Students & Card \# & \# of Students & Median \\
\hline 10.0 & 1 & $\mathrm{C} 1$ & 0 & - \\
\hline 2.0 & 1 & $\mathrm{C} 2$ & 4 & 6.5 \\
\hline 8.0 & 4 & $\mathrm{C} 3$ & 0 & - \\
\hline- & 0 & $\mathrm{C} 4$ & 5 & 4.0 \\
\hline 3.0 & 7 & C5 & 1 & 9.0 \\
\hline & 0 & $\mathrm{C} 6$ & 5 & 4.0 \\
\hline 5.5 & 4 & $\mathrm{C} 7$ & 0 & \\
\hline 8.0 & 3 & $\mathrm{C} 8$ & 6 & 5.5 \\
\hline 7.0 & 1 & C9 & 3 & 7.0 \\
\hline 10.0 & 1 & $\mathbf{C 1 0}$ & $13(76.5 \%)$ & 4.0 \\
\hline 4.0 & 8 & C11 & 0 & \\
\hline 5.5 & 4 & $\mathrm{C} 12$ & 1 & 8.0 \\
\hline 7.5 & 8 & $\overline{\mathrm{C} 13}$ & 1 & 9.0 \\
\hline 8.5 & 2 & C14 & $11(64.7 \%)$ & 6.0 \\
\hline$=$ & 0 & C15 & $13(76.5 \%)$ & $\mathbf{3 . 0}$ \\
\hline 7.0 & 3 & $\overline{C 16}$ & 1 & 9.0 \\
\hline 6.5 & 2 & $\mathrm{C} 17$ & 1 & 10.0 \\
\hline - & 0 & $\mathbf{C 1 8}$ & $13(76.5 \%)$ & 3.0 \\
\hline 6.0 & 3 & $\mathrm{C} 19$ & 4 & 8.5 \\
\hline 6.5 & 8 & $\mathbf{C 2 0}$ & $14(82.4 \%)$ & 2.0 \\
\hline 4.0 & 4 & $\mathrm{C} 21$ & 4 & 8.5 \\
\hline 3.0 & $14(82.4 \%)$ & $\overline{C 22}$ & 1 & 8.0 \\
\hline 4.0 & $9(52.9 \%)$ & $\mathbf{C 2 3}$ & 0 & - \\
\hline 7.0 & 5 & $\mathrm{C} 24$ & 5 & 5.0 \\
\hline 10.0 & 1 & $\mathrm{C} 25$ & 8 & 8.0 \\
\hline 5.0 & $9(52.9 \%)$ & $\mathrm{C26}$ & 1 & 4.0 \\
\hline 4.0 & $10(58.8 \%)$ & C27 & 2 & 8.5 \\
\hline 4.5 & 6 & $\mathrm{C} 28$ & 1 & 9.0 \\
\hline & 0 & C29 & $12(70.6 \%)$ & 4.5 \\
\hline 7.0 & 3 & $\mathrm{C} 30$ & $\frac{-6}{3}$ & 5.0 \\
\hline 4.0 & 1 & C31 & 2 & 7.0 \\
\hline 4.0 & $10(58.8 \%)$ & C32 & 6 & 2.5 \\
\hline 10.0 & 1 & $\mathrm{C} 33$ & 2 & 6.5 \\
\hline 7.0 & 3 & C34 & 6 & 6.5 \\
\hline 9.0 & 4 & C35 & 2 & 6.0 \\
\hline 6.0 & 5 & $\mathrm{C} 36$ & 1 & 5.0 \\
\hline 4.0 & 3 & C37 & $10(58.8 \%)$ & 6.0 \\
\hline 5.5 & 6 & C38 & 3 & 10.0 \\
\hline 5.5 & 4 & C39 & 0 & \\
\hline 6.0 & 6 & C40 & 2 & 6.0 \\
\hline
\end{tabular}


The ST Group Students [ $n=17]$

Negative Emotions and Experiences

\begin{tabular}{|c|c|c|c|}
\hline Rank & \# of Ss & Median & Card \\
\hline 1 & 14 & 3.0 & Returning to Japan [C22] \\
\hline 2 & 10 & 3.5 & Relationships w/ roommates; living together in apt. [C32] \\
\hline 3 & 10 & 4.0 & Speaking skills [C27] \\
\hline 4 & 9 & 4.0 & Vocabulary /idiom skills [C23] \\
\hline 5 & 9 & 5.0 & Expressing feelings in English [C26] \\
\hline 6 & 8 & 4.0 & Comparison self with other classmates [C11] \\
\hline 7 & 8 & 6.5 & Communication \& relationships with host family [C20] \\
\hline 8 & 8 & 7.5 & Keeping up English abilities after returning to Japan [C13] \\
\hline 9 & 7 & 3.0 & Gap between expectation $\&$ reality of English improvement [C5] \\
\hline 10 & 6 & 4.5 & Self personality / character [C28] \\
\hline 11 & 6 & 5.5 & Otemae program at PSU [C38] \\
\hline 12 & 6 & 6.0 & Gap between the reality and expectation of studying in US [C40] \\
\hline 13 & 5 & 6.0 & Racial discrimination / prejudice [C36] \\
\hline 14 & 5 & 7.0 & Relationships with friends [C24] \\
\hline 15 & 4 & 4.0 & PSU ESL program [C21] \\
\hline \multirow[t]{3}{*}{16} & 4 & 5.5 & English pronunciation [C12] \\
\hline & 4 & 5.5 & Knowledge of Japan and its culture [C39] \\
\hline & 4 & 5.5 & English grammar skills [C7] \\
\hline 19 & 4 & 8.0 & Homesickness [C3] \\
\hline 20 & 4 & 9.0 & Future plans after graduating from school [C35] \\
\hline 21 & 3 & 4.0 & Listening skills [C37] \\
\hline 22 & 3 & 6.0 & Class projects (presentation, speech, etc.) [C19] \\
\hline \multirow[t]{3}{*}{23} & 3 & 7.0 & Communication \& relationships with conversation partner [C30] \\
\hline & 3 & 7.0 & How to spend time in the US until leaving [C16] \\
\hline & 3 & 7.0 & Culture \& tradition differences [C34] \\
\hline 26 & 3 & 8.0 & Different ways of thinking / perceiving [C8] \\
\hline 27 & 2 & 6.5 & Reading skills [C17] \\
\hline 28 & 2 & 8.5 & Everyday communication [C14] \\
\hline 29 & 1 & 2.0 & Self recognition as Japanese [C2] \\
\hline 30 & 1 & 4.0 & How to study / improve English [C31] \\
\hline 31 & 1 & 7.0 & PSU undergraduate program [C9] \\
\hline \multirow[t]{9}{*}{32} & 1 & 10.0 & Grades [C1] \\
\hline & 1 & 10.0 & Challenging various new things [C10] \\
\hline & 1 & 10.0 & Lesson/classroom procedure (Japan vs. US) [C25] \\
\hline & 1 & 10.0 & Writing skills [C33] \\
\hline & $\mathbf{0}$ & - & Self improvement through communication [C4] \\
\hline & 0 & - & Discover "self" [C6] \\
\hline & $\mathbf{0}$ & - & Personal growth [C15] \\
\hline & $\mathbf{0}$ & - & Thinking about what I never thought about before [C18] \\
\hline & $\mathbf{0}$ & - & Encouragement, advice from teachers and others [C29] \\
\hline
\end{tabular}




\section{The ST Group Students [n=17]}

\section{Positive Emotions and Experiences}

\begin{tabular}{|c|c|c|c|}
\hline Rank & \# of Ss & Median & Card \\
\hline 1 & 14 & 2.0 & Communication \& relationships with host family [C20] \\
\hline 2 & 13 & 3.0 & Thinking about what I never thought about before [C18] \\
\hline & 13 & 3.0 & Personal growth [C15] \\
\hline$\overline{4}$ & 13 & 4.0 & Challenging various new things [C10] \\
\hline 5 & 12 & 4.5 & Encouragement, advice from teachers and others [C29] \\
\hline 6 & 11 & 6.0 & Everyday communication [C14] \\
\hline 7 & 10 & 6.0 & Listening skills [C37] \\
\hline 8 & 8 & 8.0 & Lesson/classroom procedure (Japan vs. US) [C25] \\
\hline 9 & 6 & 2.5 & Relationships w/ roommates; living together in apt. [C32] \\
\hline 10 & 6 & 5.5 & Different ways of thinking / perceiving [C8] \\
\hline 11 & 6 & 6.5 & Culture and tradition differences [C34] \\
\hline 12 & 5 & 4.0 & Self improvement through communication $[\mathrm{C4}]$ \\
\hline & 5 & 4.0 & Discover "self"[C6] \\
\hline 14 & 5 & 5.0 & Relationships with friends [C24] \\
\hline 15 & 4 & 6.5 & Self recognition as Japanese [C2] \\
\hline 16 & 4 & 8.5 & Class projects (Presentation, speech, etc.) [C19] \\
\hline & 4 & 8.5 & PSU ESL program [C21] \\
\hline 18 & 3 & 5.0 & Communication \& relationships with conversation partners [C30] \\
\hline 19 & 3 & 7.0 & PSU undergraduate program [C9] \\
\hline 20 & 3 & 10.0 & Otemae program at PSU [C38] \\
\hline$\overline{21}$ & 2 & 6.0 & Future plan after graduating from school [C35] \\
\hline & 2 & 6.0 & Gap between the reality \& expectation of studying in US [C40] \\
\hline 23 & 2 & 6.5 & Writing skills [C33] \\
\hline 24 & 2 & 7.0 & How to study/improve English (in general) [C31] \\
\hline 25 & 2 & 8.5 & Speaking skills [C27] \\
\hline 26 & 1 & 4.0 & Expressing feelings in English [C26] \\
\hline 27 & 1 & 5.0 & Racial discrimination / prejudice [C36] \\
\hline 28 & 1 & 8.0 & English pronunciation [C12] \\
\hline & 1 & 8.0 & Returning to Japan [C22] \\
\hline 30 & 1 & 9.0 & Gap between expectation and reality of Eng. improvement [C5] \\
\hline & 1 & 9.0 & Keeping up English abilities after returning to Japan [C13] \\
\hline & 1 & 9.0 & How to spend time in the US until leaving [C16] \\
\hline & 1 & 9.0 & Self personality / character [C28] \\
\hline 34 & 1 & 10.0 & Reading skills [C17] \\
\hline & 0 & - & Grades [C1] \\
\hline & 0 & - & Homesickness [C3] \\
\hline & 0 & - & English grammar skills [C7] \\
\hline & $\mathbf{0}$ & - & Comparison between self and other classmate [C11] \\
\hline & $\mathbf{0}$ & - & Vocabulary/idiom skills [C23] \\
\hline & 0 & - & Knowledge of Japan and its culture [C39] \\
\hline
\end{tabular}

